\title{
Seismic Studies
}

Prepared for:

U.S. Department of Energy

Office of Civilian Radioactive Waste Management

Office of Repository Development

1551 Hillshire Drive

Las Vegas, Nevada 89134-6321

Prepared by:

Bechtel SAIC Company, LLC

1180 Town Center Drive

Las Vegas, Nevada 89144

Under Contract Number

DE-AC28-01RW12101 


\section{DISCLAIMER}

This report was prepared as an account of work sponsored by an agency of the United States Government. Neither the United States Government nor any agency thereof, nor any of their employees, nor any of their contractors, subcontractors or their employees, makes any warranty, express or implied, or assumes any legal liability or responsibility for the accuracy, completeness, or any third party's use or the results of such use of any information, apparatus, product, or process disclosed, or represents that its use would not infringe privately owned rights. Reference herein to any specific commercial product, process, or service by trade name, trademark, manufacturer, or otherwise, does not necessarily constitute or imply its endorsement, recommendation, or favoring by the United States Government or any agency thereof or its contractors or subcontractors. The views and opinions of authors expressed herein do not necessarily state or reflect those of the United States Government or any agency thereof. 
Seismic Studies

\section{TWP-MGR-GS-000001 REV 005}

September 2006 
INTENTIONALLY LEFT BLANK 
Bechtel SAIC Company, LLC

Technical Work Plan for:

SEISMIC STUDIES

TWP-MGR-GS-000001 REV 005

September 2006

Prepared by:

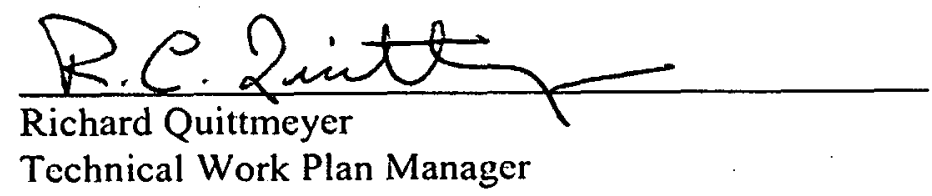

Approved by:

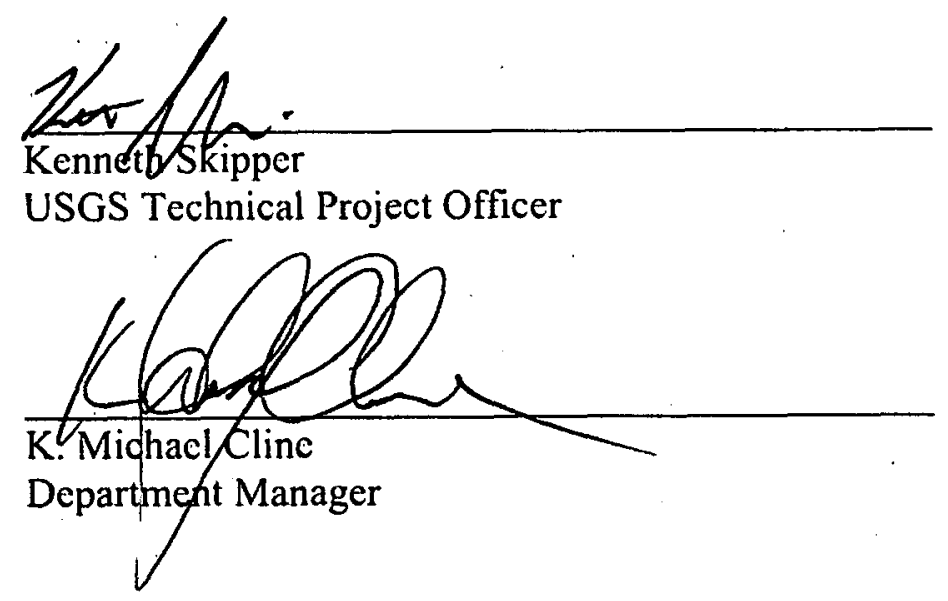

$\frac{09 / 21 / 2006}{\text { Date }}$

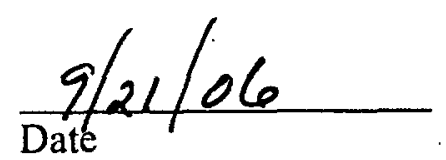




\section{CHANGE HISTORY}

\section{Revision ICN Date of \\ Number Number}

0

1

2

3

$02 / 19 / 2004$

$10 / 19 / 2000$

$02 / 28 / 2002$

$12 / 28 / 2002$ require to incorporate changes in ISPA docut ba rine, baseline, and to comply with AP-2.27Q. Extensive changes were required so this document is revised without the use of vertical change bars in the margin.

Initial issue. This plan supercedes Technical Development Plan TDP-MGR-GS-000003, Rev 00.

Update Technical Work Plan to reflect fiscal year 2002-2005 work scopes.

Complete revision. Update to provide additional detail for work on ground motion saturation; changes to the list of seismic features, events, and processes; new testing to support development of seismic inputs, and seismic topical reports. Also modified to address requirements of new revision of $\mathrm{AP}-2.27 \mathrm{Q}$. Changes are extensive; thus change bars are not used. This revision supersedes TWP-MGR-GS-000001, Rev 02, Technical Work Plan for: Development of Seismic Design Inputs, Preparation of a Seismic Topical Report, and Evaluation of Disruptive Events Features, Events, and Processes.

$31 \quad 05 / 27 / 2004$

Interim Change Notice to describe new work consisting of an analysis to determine low probability peak horizontal ground velocities at Yucca Mountain. New work is also planned to revise existing reports, as needed, to address issues identified as part of the evaluation by the Regulatory Integration Team. Also, work to prepare the topical report Preclosure Vibratory Ground Motion and Fault Displacement Design Inputs for a Geologic Repository at Yucca Mountain (also referred to as STR\#3) has been cancelled; thus the work is deleted from this plan. In addition, changes are made to clarify that the probabilistic seismic hazard analysis that was performed previously is an expert elicitation and not a modeling activity. Finally, work package numbers for testing activities are updated. This interim change notice supersedes TWP-MGR-GS-000001, Rev 03, Technical Work Plan for: Development of Seismic Inputs, Preparation of Seismic Topical Reports, and 


\title{
CHANGE HISTORY (Continued)
}

\author{
Revision ICN Date of \\ Number Number Change \\ Description of Change
}

32

09/20/04 Interim Change Notice to describe new testing consisting of Linear and nonlinear measurements of the cemented alluvium in the Surface Facilities Area to be performed in the field and in the laboratory. Added a product to document the testing and the analysis of the acquired data. This information will be presented in a new Geotechnical Data and Analysis Report. This interim change notice supersedes TWP-MGR-GS-000001, Rev 03, ICN 01 Technical Work Plan for: Development of Seismic Inputs, Preparation of Seismic Topical Reports, and Evaluation of Disruptive Events Features, Events, and Processes.

06/16/2005 Complete revision to describe updated work scope and to bring into compliance with LP-2.29Q-BSC, Revision 0, ICN 0, Planning for Science Activities. This plan supersedes TWP-MGR-GS-000001, Rev 03, ICN 02 Technical Work Plan for: Development of Seismic Inputs, Preparation of Seismic Topical Reports, and Evaluation of Disruptive Events Features, Events, and Processes.

09/13/2006 Revision to update work scope consistent with current plans and to address requirements of LP-2.29Q-BSC, Revision 1. Because revisions are extensive, change bars are not provided. This plan supersedes TWP-MGR-GS-000001, Rev 04, Seismic Studies. 
INTENTIONALLY LEFT BLANK 


\section{CONTENTS}

Page

ACRONYMS. xiii

1. WORK SCOPE

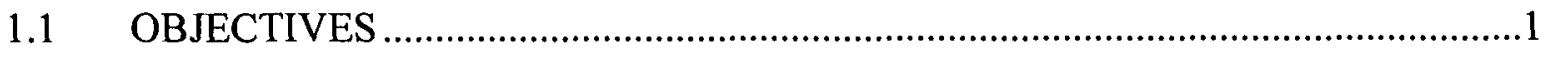

1.2 MAJOR ACTIVITIES, TASKS, AND PRODUCTS .................................................

1.3 RESPONSIBLE ORGANIZATIONS FOR WORK AND PRODUCTS ...................20

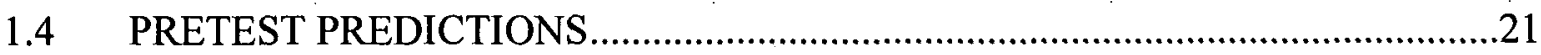

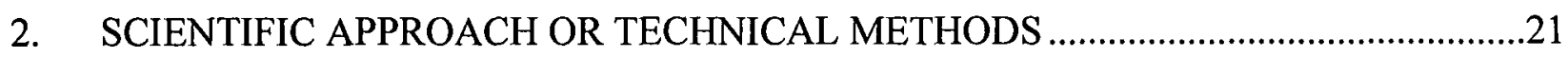

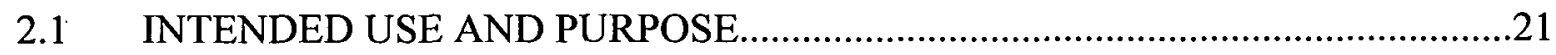

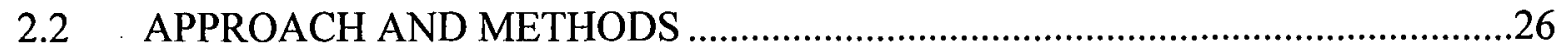

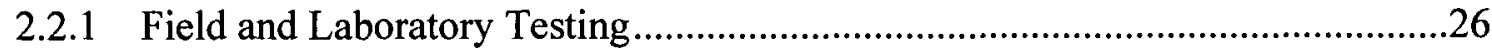

2.2.2 Velocity Profile Development .............................................................................31

2.2.3 Dynamic Material Property Curve Development ..................................................32

2.2.4 Enhancement of Technical Basis for Model Validation.........................................33

2.2.5 Update Site Response Model ..............................................................................35

2.2.6 Update Preclosure Ground Motions.....................................................................36

2.2.7 Update YMP/TR-003-NP, Preclosure Seismic Design Methodology for a Geologic Repository at Yucca Mountain ...........................................................37

2.2.8 Update Postclosure Ground Motions ........................................................................38

2.2.9 Evaluate Impact of New Data on the PSHA Results ...........................................40

2.2.10 Develop a Seismic Hazard Curve for the Surface Facilities Area ........................41

2.3 MODEL USE AND MODEL VALIDATION ....................................................41

2.3.1 Geologic Framework Model .........................................................................41

2.3.2 PFC Discontinuum Model (PCF2D, PCF3D) ……..............................................42

2.3.3 UDEC Discontinuum Model (UDEC, 3DEC) ..................................................42

2.3.4 RVT-based Equivalent-linear Site-response Model (RASCALS SET)...............43

2.3.5 RVT-based Point-Source Ground Motion Model (RASCAL SET) ….................44

2.3.6 RVT-based Finite-Source Ground Motion Model (RASCALFS) ........................45

3. INDUSTRY STANDARDS, FEDERAL REGULATIONS, DOE ORDERS, REQUIREMENTS, AND ACCEPTANCE/COMPLETION CRITERIA ………………......47

$3.1 \quad$ APPLICABLE STANDARDS ……………...................................................47

3.2 REGULATORY REQUIREMENTS..............................................................47

3.3 LEVEL OF ACCURACY, PRECISION, AND REPRESENTATIVENESS

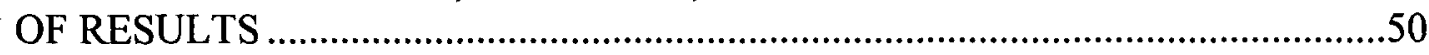

3.4 ACCEPTANCE/COMPLETION CRITERIA ……….......................................5

3.5 REQUIREMENTS MANAGEMENT SYSTEM REQUIREMENTS ......................53

3.6 REQUIREMENTS IDENTIFIED IN SOURCE DOCUMENTS...............................53

4. IMPLEMENTING DOCUMENTS ………………........................................................5

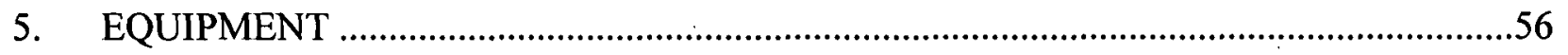




\section{CONTENTS (Continued)}

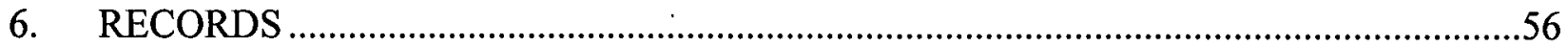

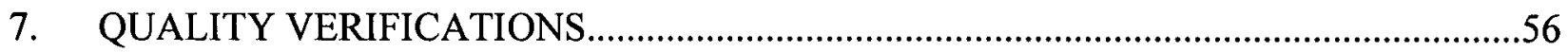

8. PREREQUISITES, SPECIAL CONTROLS, ENVIRONMENTAL CONDITIONS,

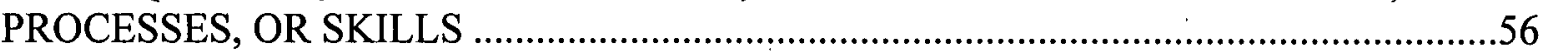

8.1 DETERMINATION OF THE APPLICABILITY OF REQUIREMENTS OF THE

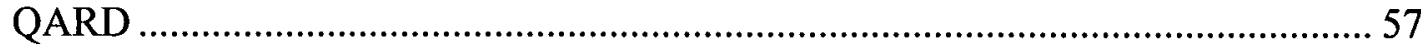

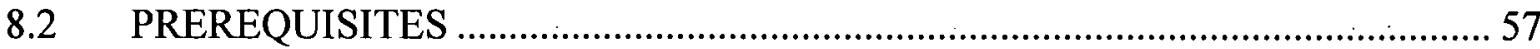

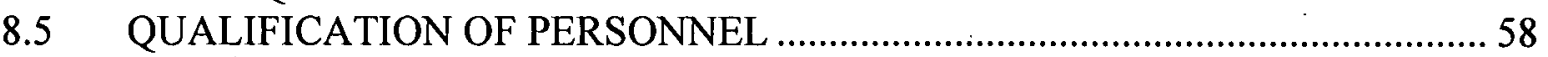

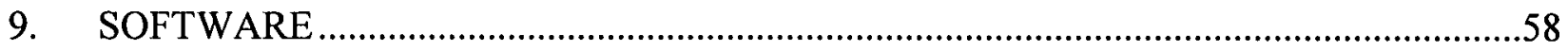

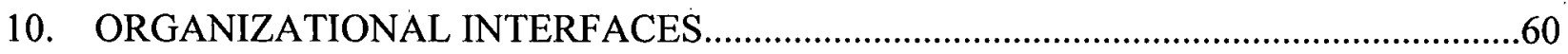

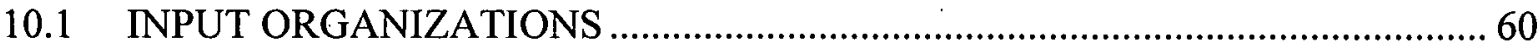

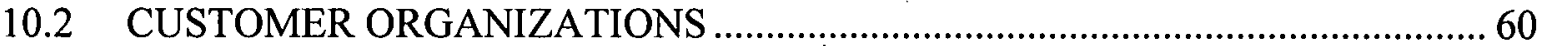

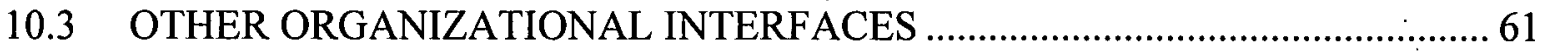

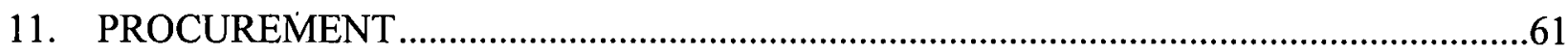

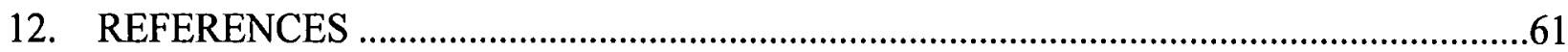

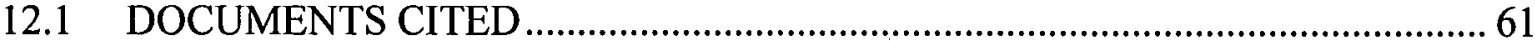

12.2 CODES, STANDARDS, REGULATIONS, AND PROCEDURES ……………........65

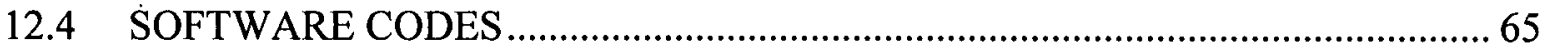

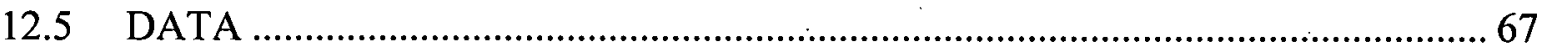




\section{LIST OF TABLES}

Page

1. Relation of Planned Activities, Tasks, and Products to the License Application........................5

2. Seismic-related Features, Events, and Processes....................................................................26

3. Yucca Mountain Review Plan Acceptance Criteria and Products Developed under this Technical Work Plan that Address the Criteria

4. Yucca Mountain Review Plan Acceptance Criteria and Products Developed under this Technical Work Plan that Address the Criteria .53

5. Software to be used in Work Subject to Requirements of the QARD. .58 


\section{INTENTIONALLY LEFT BLANK}




\section{ACRONYMS}

3DEC

AQAP

ASTM

BCP

BOR

BSC

CR

DBGM

DIRS

DOE

EBS

ECRB

ESF

FY

NRC

PCA

PFC

PSHA

QARD

RCTS

RPM

RVT

SASW

TDMS

TSPA

TWP

UDEC

USGS

YMRP
3-Dimensional Discrete Element Code

Augmented Quality Assurance Program

American Society for Testing Materials

baseline change proposal

U.S. Bureau of Reclamation

Bechtel SAIC Company, LLC

condition report

design basis ground motion

Document Input Reference System

U.S. Department of Energy

engineered barrier system

Enhanced Characterization of the Repository Block

Exploratory Studies Facility

fiscal year

U.S. Nuclear Regulatory Commission

Postclosure Activities organization

particle flow code

probabilistic seismic hazard analysis

Quality Assurance Requirements and Description

resonant column and torsional shear (testing)

Repository Project Management

random vibration theory

spectral-analysis-of-surface-waves

Technical Data Management System

total system performance assessment

technical work plan

Universal Discrete Element Code

U.S. Geological Survey

Yucca Mountain Review Plan, Final Report 
INTENTIONALLY LEFT BLANK 


\section{WORK SCOPE}

This technical work plan (TWP) describes the efforts to develop and confirm seismic ground motion inputs used for preclosure design and probabilistic safety analyses and to assess the postclosure performance of a repository at Yucca Mountain, Nevada. As part of the effort to develop seismic inputs, the TWP covers testing and analyses that provide the technical basis for inputs to the seismic ground-motion site-response model. The TWP also addresses preparation of a seismic methodology report for submission to the U.S. Nuclear Regulatory Commission (NRC).

The activities discussed in this TWP are planned for fiscal years (FY) 2006 through 2008. Some of the work enhances the technical basis for previously developed seismic inputs and reduces uncertainties and conservatism used in previous analyses and modeling. These activities support the defense of a license application. Other activities provide new results that will support development of the preclosure safety case; these results directly support and will be included in the license application. Table 1 indicates which activities support the license application and which support licensing defense. The activities are listed in Section 1.2; the methods and approaches used to implement them are discussed in more detail in Section 2.2.

\subsection{OBJECTIVES}

Technical and performance objectives of this work scope are:

- For annual ground motion exceedance probabilities appropriate for preclosure design analyses, provide site-specific seismic design acceleration response spectra for a range of damping values; strain-compatible soil properties; peak motions, strains, and curvatures as a function of depth; and time histories (acceleration, velocity, and displacement). Provide seismic design inputs for the waste emplacement level and for surface sites. Results should be consistent with the probabilistic seismic hazard analysis (PSHA) for Yucca Mountain and reflect, as appropriate, available knowledge on the limits to extreme ground motion at Yucca Mountain.

- For probabilistic analyses supporting the demonstration of compliance with preclosure performance objectives, provide a mean seismic hazard curve for the surface facilities area. Results should be consistent with the PSHA for Yucca Mountain and reflect, as appropriate, available knowledge on the limits to extreme ground motion at Yucca Mountain.

- For annual ground motion exceedance probabilities appropriate for postclosure analyses, provide site-specific seismic time histories (acceleration, velocity, and displacement) for the waste emplacement level. Time histories should be consistent with the PSHA and reflect available knowledge on the limits to extreme ground motion at Yucca Mountain.

- In support of ground-motion site-response modeling, perform field investigations and laboratory testing to provide a technical basis for model inputs. Characterize the repository block and areas in which important-to-safety surface facilities will be sited. 
Work should support characterization and reduction of uncertainties in inputs to groundmotion site-response modeling.

- On the basis of rock mechanics, geologic, and seismic information, determine limits on extreme ground motion at Yucca Mountain and document the technical basis for them.

- Update the ground-motion site-response model, as appropriate, on the basis of new data. Expand and enhance the technical basis for model validation to further increase confidence in the site-response modeling.

- Document seismic methodologies and approaches in reports to be submitted to the NRC.

- Address condition reports.

Current ground motions for the surface facilities area are based on subsurface velocity data obtained southwest of the Exile Hill splay fault (BSC 2004 [DIRS 170027] ${ }^{1}$, Sections 6.2.3 and 6.3.1). Subsequent to the development of these ground motions, the layout of surface facilities evolved and now extends to the north and northeast of the area originally characterized. A sensitivity study based on available data for the area northeast of the Exile Hill splay fault indicated that computed ground motions are comparable (horizontal) to slightly elevated (vertical) relative to those for the area southwest of the fault (BSC 2004 [DIRS 170027], Section 6.3.5). The planned work scope will lead to an update of the design ground motions determined for the surface facility area that incorporates results of additional borings and seismic surveys covering the expanded extent of planned surface facilities. Velocity profiles will be updated in two phases. In the first phase, velocity profiles will be based on geotechnical data available in October 2006. Modeling using these inputs will lead to updated preclosure ground motions for design and preclosure safety analyses supporting the license application. In the second phase, velocity profiles will be updated based on the complete set of geotechnical data from planned investigations available in 2008. Updated ground motions based on these profiles will be used to confirm existing design ground motions and will be used for licensing defense.

Current ground motions for both the surface facilities area and the waste emplacement level incorporate uncertainties in knowledge of dynamic material properties (shear modulus reduction, damping) at the site (BSC 2004 [DIRS 170027], Section 6.2.4; DTN: MO0403SDIAWHBC.003 [DIRS 170434]). Recent and ongoing geotechnical investigations will provide additional information that may reduce uncertainties in these inputs to the ground-motion site-response model. Such investigations are focused on a better understanding of seismic velocities across the site and on the variation in shear modulus and damping as a function of shear strain for tuff and alluvium. The planned work scope will lead to an update of the dynamic material properties used as input to site-response modeling that reduces, as appropriate, the amount of uncertainty incorporated into site-specific ground motions. As for the velocity profiles, dynamic material property curves will be updated in two phases: one based on geotechnical data available in October 2006, and the other based on the complete set of geotechnical data from planned investigations available in 2008. Updated ground motions developed using the updated dynamic

\footnotetext{
${ }^{1}$ The Document Input Reference System (DIRS) number provides a unique identification of the input source.
} 
material properties from the first phase will be used for design and preclosure safety analyses supporting the license application. Updated ground motions using the second phase properties will be used to confirm existing ground motions used for design and performance assessment analyses and will be used for licensing defense.

Current time histories developed for postclosure analyses (BSC 2004 [DIRS 170027], Section 6.3.2.3) do not reflect that, at some level of extreme ground motion, the rocks will likely be damaged by the seismically induced increment in shear strain. This bound to ground motion is currently incorporated as part of the seismic consequence abstraction (BSC 2005 [DIRS 173247]), rather than in the time histories used for analyses. The time histories thus represent ground motions that the rocks at Yucca Mountain may not be able to sustain. While these time histories are useful to examine the sensitivity of seismic consequences to extreme levels of ground motion, an objective of the planned work scope is to develop time histories that are consistent with evidence that ground motions at Yucca Mountain can be reasonably bounded (BSC 2005 [DIRS 170137]). Such ground motions will support any future, more-realistic evaluations of seismic consequences during the postclosure period that are performed for licensing defense. Updated ground motions will be used to confirm that existing ground motions used for performance assessment analyses are adequate or conservative.

Validation of the random-vibration-theory-based equivalent-linear site-response model was described in Development of Earthquake Ground Motion Input for Preclosure Seismic Design and Postclosure Performance Assessment of a Geologic Repository at Yucca Mountain, NV (BSC 2003 [DIRS 166274], Section 7) (MDL-MGR-GS-000003 Rev 00). A supplemental model validation activity was described in MDL-MGR-GS-000003 Rev 01 (BSC 2004 [DIRS 170027], Section 7.3.5). While model validation is complete, future activities are planned whose objective is to enhance the technical basis for the existing model to achieve even greater confidence in the model. This work supports defense of the license application.

The U.S. Department of Energy (DOE) described their preclosure seismic design methodology in Preclosure Seismic Design Methodology for a Geologic Repository at Yucca Mountain (DOE 2004 [DIRS 172373]) (YMP/TR-003-NP, REV 03), which was transmitted to the NRC in November 2004. The methodology defined two levels of Design Basis Ground Motion (DBGM1 and DBGM-2) with associated mean annual probabilities of exceedance of $1 \times 10^{-3}$ and $5 \times 10^{-4}$, respectively. In addition, a seismic margin assessment was included in the methodology using a Beyond Design Basis Ground Motion (BDBGM) with a mean annual probability of exceedance of $1 \times 10^{-4}$. In a January 2006 letter (Kokajko 2006 [DIRS 176995]), the NRC indicated that the design basis ground motion levels appeared to be acceptable, but that probabilistic analyses in addition to a seismic margin assessment would be required to demonstrate compliance with the preclosure performance objectives of 10 CFR 63 [DIRS 176544]. An objective of the planned work scope is to prepare a methodology report that updates the existing topical report to respond to the issues raised in the NRC letter and to NRC Draft Interim Staff Guidance Document HLWRS-ISG-01 (71 FR 29369 [DIRS 177351]). This activity supports the preclosure safety case that will be described in the license application. 
The planned work scope will also address issues raised in the following relevant Condition Reports (CRs):

- 3238-Documents the condition that CR 676 was closed prematurely. CR 676 stated that geotechnical investigations to characterize the Yucca Mountain site for development of seismic inputs for design analyses were inadequate. CR 676 was closed when a plan to perform additional geotechnical investigations was approved. CR 3238 indicated that closure of CR 676 should have waited until the planned work was performed. Field and laboratory testing work and subsequent analyses described in this TWP address the condition originally documented in CR 676 . Completion of this work will allow CR 3238 to be closed in FY 2007.

- 5824-Documents the condition that discussion of model validation in MDL-MGR-GS000003 REV 01 does not discriminate well between work done to validate the model and work done to expand and enhance the technical basis for model validation beyond that required. Planned work described in this TWP to revise MDL-MGR-GS-000003 in FYs 2007 and 2008 will allow the distinction between these two classes of work to be distinguished more clearly. This will allow CR 5824 to be closed.

- 8041-Documents the condition that the impact of new potentially relevant data on the results of the probabilistic seismic hazard analysis (PSHA) for Yucca Mountain has not been evaluated in a timely manner as required by PA-PRO-0202 (Section 4.13.1). The PSHA, which provides the uniform hazard spectra forming one of the inputs to siteresponse modeling, was performed between 1994 and 1998. Since then, new data that are potentially relevant to the PSHA interpretations' have been collected by YMP personnel and those outside the YMP. An objective of the planned work scope for FY 2007 is to compile and evaluate the impact of such data. A trend will be developed to initiate this work scope in FY 2006 to address the condition in a timelier manner.

- 8438-Documents the condition that a test case for software item NFITM V3.4 did not completely exercise the range of input parameters consistent with the intended use of the code. Work is included in the current plan to qualify an updated version of the code (NFITM 3.41). Qualification of the updated code will also address the condition documented in CR 8438.

\subsection{MAJOR ACTIVITIES, TASKS, AND PRODUCTS}

Major activities, tasks, and products associated with the planned work will occur over a multiyear period. In the listing of planned activities that follows, the fiscal year(s) in which tasks will be performed are shown. For completeness, some tasks that were initiated under the previous version of this TWP are shown as being under way in FY 2005. The intended use and purpose of the activities and products are discussed in Section 2.1.

Table 1 identifies whether each item supports preparation of the license application or defense of the license application. If an item supports preparation of the license application, the results of that item will be used in subsequent analyses, modeling, or calculations that will be documented in the license application. If an item supports licensing defense, its results will not form part of 
the basis for subsequent work documented in the license application. However, the results themselves may still be documented in the license application as confirmatory if they are available in time. Alternatively, they may be completed after preparation of the license application is finished to support Requests for Additional Information or the postsubmittal licensing process. Table 1 also identifies whether the each item primarily supports preclosure activities, postclosure activities, or both.

Table 1. Relation of Planned Activities, Tasks, and Products to the License Application

\begin{tabular}{|c|c|c|}
\hline Activity, Task, or Product & $\begin{array}{l}\text { Support to } \\
\text { Preclosure or } \\
\text { Postclosure } \\
\text { Analyses and } \\
\text { Modeling }\end{array}$ & $\begin{array}{l}\text { Support to License } \\
\text { Application or } \\
\text { Licensing Defense }\end{array}$ \\
\hline \multicolumn{3}{|l|}{ PLANNED ACTIVITIES AND TASKS } \\
\hline \multicolumn{3}{|c|}{$\begin{array}{l}\text { Laboratory and field testing to provide the technical basis for ground-motion site-response modeling and surface } \\
\text { facilities foundation design: }\end{array}$} \\
\hline $\begin{array}{l}\text { Drill } 35 \text { boreholes (Phase 2) to further characterize the surface } \\
\text { facilities area in the vicinity of the North Portal of the Exploratory } \\
\text { Studies Facility (ESF) and the Aging Pad west of the Bow Ridge } \\
\text { fault. (FYs 2005, 2006, and 2007) }\end{array}$ & Preclosure & $\begin{array}{l}\text { License application } \\
\text { (for data collected by } \\
\text { October 2006) } \\
\text { Licensing defense (for } \\
\text { remaining data) }\end{array}$ \\
\hline $\begin{array}{l}\text { Perform geologic logging of new boreholes in the surface facilities } \\
\text { area and at the Aging Pad site west of the Bow Ridge fault. (FYs } \\
2006 \text { and 2007) }\end{array}$ & Preclosure & $\begin{array}{l}\text { License application } \\
\text { (for data collected by } \\
\text { October 2006) } \\
\text { Licensing defense (for } \\
\text { remaining data) }\end{array}$ \\
\hline $\begin{array}{l}\text { Perform downhole velocity surveys in } 14 \text { of the new boreholes } \\
\text { (Phase 2). (FY 2007) }\end{array}$ & Preclosure & Licensing defense \\
\hline $\begin{array}{l}\text { Perform geophysical logging in } 8 \text { of the new boreholes (Phase } 2 \text { ). } \\
\text { (FY 2007) }\end{array}$ & Preclosure & Licensing defense \\
\hline $\begin{array}{l}\text { Perform additional spectral-analysis-of-surface-wave (SASW) } \\
\text { surveys. (FYs } 2005 \text { and 2006) }\end{array}$ & $\begin{array}{l}\text { Preclosure } \\
\text { Postclosure }\end{array}$ & $\begin{array}{l}\text { License application } \\
\text { Licensing defense }\end{array}$ \\
\hline $\begin{array}{l}\text { Attempt to obtain hand-carved samples of alluvium (4-in to 6-in } \\
\text { diameter) for laboratory dynamic testing. (FY 2006) }\end{array}$ & Preclosure & Licensing defense \\
\hline $\begin{array}{l}\text { Perform additional laboratory testing of dynamic material } \\
\text { properties for existing and new samples. (FYs 2005, 2006, and } \\
2007 \text { ) }\end{array}$ & Preclosure & $\begin{array}{l}\text { License application } \\
\text { (for data collected by } \\
\text { October 2006) }\end{array}$ \\
\hline & $\begin{array}{l}\text { Preclosure and } \\
\text { Postclosure }\end{array}$ & $\begin{array}{l}\text { Licensing defense (for } \\
\text { remaining data) }\end{array}$ \\
\hline $\begin{array}{l}\text { Test 4-in and 6-in diameter tuff and alluvium samples to study } \\
\text { sample size effects (i.e., effects of fractures in the tuff and grain } \\
\text { size in the alluvium). (FYs } 2006 \text { and 2007) }\end{array}$ & $\begin{array}{l}\text { Preclosure and } \\
\text { Postclosure }\end{array}$ & Licensing defense \\
\hline $\begin{array}{l}\text { Perform laboratory testing of the alluvium samples to determine } \\
\text { static properties, including density, moisture content, and } \\
\text { compaction. (FY 2006) }\end{array}$ & Preclosure & License application \\
\hline $\begin{array}{l}\text { Confirm through field investigations and other analyses that } \\
\text { pervasive, seismic-related, inter-lithophysal fractures are not } \\
\text { observed in the ESF and ECRB Cross-Drift. (FY 2006) }\end{array}$ & $\begin{array}{l}\text { Preclosure and } \\
\text { Postclosure }\end{array}$ & Licensing defense \\
\hline
\end{tabular}


Table 1. Relation of Planned Activities, Tasks, and Products to the License Application (Continued)

\begin{tabular}{|c|c|c|}
\hline Activity, Task, or Product & $\begin{array}{l}\text { Support to } \\
\text { Preclosure or } \\
\text { Postclosure } \\
\text { Analyses and } \\
\text { Modeling } \\
\end{array}$ & $\begin{array}{l}\text { Support to License } \\
\text { Application or } \\
\text { Licensing Defense }\end{array}$ \\
\hline \multicolumn{3}{|l|}{ PLANNED ACTIVITIES AND TASKS } \\
\hline \multirow{2}{*}{$\begin{array}{l}\text { Submit new data to the Technical Data Management System } \\
\text { (TDMS), supplementing or superseding existing data, as } \\
\text { appropriate. Perform an impact review to evaluate the impact of } \\
\text { the new data on existing analyses and modeling. (FYs } 2006 \text { and } \\
2007 \text { ) }\end{array}$} & Preclosure & $\begin{array}{l}\text { License application } \\
\text { (for data submitted by } \\
\text { October 2006) }\end{array}$ \\
\hline & $\begin{array}{l}\text { Preclosure and } \\
\text { Postclosure }\end{array}$ & $\begin{array}{l}\text { Licensing defense (for } \\
\text { remaining data) }\end{array}$ \\
\hline $\begin{array}{l}\text { Drill } 44 \text { additional boreholes (Phase } 3 \text { ) to characterize the depth of } \\
\text { alluvium and geology in the vicinity of new areas where facilities } \\
\text { will be sited to implement an approach that involves receipt of } \\
\text { waste at Yucca Mountain that is mostly contained in multipurpose } \\
\text { transportable, ageable, and disposable (TAD) canisters. (FYs } \\
2007 \text { and 2008) }\end{array}$ & Preclosure & License defense \\
\hline $\begin{array}{l}\text { Perform geophysical logging and downhole seismic surveys in the } \\
\text { additional deeper boreholes (Phase 3). (FY 2007) }\end{array}$ & Preclosure & License defense \\
\hline $\begin{array}{l}\text { Excavate and log trenches and test pits to characterize site } \\
\text { materials and confirm the absence of active faulting, including a } \\
\text { trench in the vicinity of the Initial Handling Facility. (FY 2007) }\end{array}$ & Preclosure & License defense \\
\hline $\begin{array}{l}\text { Perform additional SASW surveys (Phase } 3 \text { ) to extend the spatial } \\
\text { coverage of velocity surveys to include new areas where facilities } \\
\text { will be sited. (FY 2007) }\end{array}$ & Preclosure & License defense \\
\hline $\begin{array}{l}\text { Submit additional data (Phase } 3 \text { ) to the TDMS. Carry out an } \\
\text { impact review to evaluate the impact of the new data on existing } \\
\text { analyses and modeling. (FYs } 2007 \text { and 2008) }\end{array}$ & Preclosure & License defense \\
\hline \multicolumn{3}{|l|}{ Update velocity profiles for the repository block and surface facilities area: } \\
\hline \multirow[t]{2}{*}{$\begin{array}{l}\text { Evaluate the correlation between velocity layering and } \\
\text { lithostratigraphic contacts and/or properties. To support this } \\
\text { effort, develop a three-dimensional representation of the geology } \\
\text { beneath the surface facilities area. (FYs 2006, 2007, and 2008) }\end{array}$} & Preclosure & $\begin{array}{l}\text { License application } \\
\text { (based on data } \\
\text { collected by October } \\
\text { 2006) }\end{array}$ \\
\hline & $\begin{array}{l}\text { Preclosure and } \\
\text { Postclosure }\end{array}$ & $\begin{array}{l}\text { Licensing defense } \\
\text { (based on data from all } \\
\text { planned geotechnical } \\
\text { investigations) }\end{array}$ \\
\hline \multirow[t]{2}{*}{$\begin{array}{l}\text { Reconcile, if possible, velocity data collected by different } \\
\text { techniques. (FYs } 2006 \text { and 2007) }\end{array}$} & Preclosure & $\begin{array}{l}\text { License application } \\
\text { (based on data } \\
\text { collected by October } \\
\text { 2006) }\end{array}$ \\
\hline & $\begin{array}{l}\text { Preclosure and } \\
\text { Postclosure }\end{array}$ & $\begin{array}{l}\text { Licensing defense } \\
\text { (based on data from all } \\
\text { planned geotechnical } \\
\text { investigations) }\end{array}$ \\
\hline $\begin{array}{l}\text { Based on geotechnical data available in October } 2006 \text {, develop } \\
\text { updated velocity profiles to be used as input to ground-motion } \\
\text { site-response modeling for preclosure analyses supporting the } \\
\text { license application. (FY 2007) }\end{array}$ & Preclosure & License application \\
\hline
\end{tabular}


Table 1. Relation of Planned Activities, Tasks, and Products to the License Application (Continued)

\begin{tabular}{|c|c|c|}
\hline Activity, Task, or Product & $\begin{array}{l}\text { Support to } \\
\text { Preclosure or } \\
\text { Postclosure } \\
\text { Analyses and } \\
\text { Modeling } \\
\end{array}$ & $\begin{array}{l}\text { Support to License } \\
\text { Application or } \\
\text { Licensing Defense }\end{array}$ \\
\hline \multicolumn{3}{|l|}{ PLANNED ACTIVITIES AND TASKS } \\
\hline $\begin{array}{l}\text { Based on previous and new data from the complete set of } \\
\text { planned geotechnical investigations, update velocity profiles for } \\
\text { the repository block and surface facilities area. (FYs } 2007 \text { and } \\
2008 \text { ) }\end{array}$ & $\begin{array}{l}\text { Preclosure and } \\
\text { Postclosure }\end{array}$ & Licensing defense \\
\hline $\begin{array}{l}\text { Based on previous and new data, update the analysis of } \\
\text { correlation between velocity and layer thickness as a function of } \\
\text { depth for the repository block and surface facilities area. } \\
\text { (FYs } 2007 \text { and 2008) }\end{array}$ & $\begin{array}{l}\text { Preclosure and } \\
\text { Postclosure }\end{array}$ & Licensing defense \\
\hline $\begin{array}{l}\text { Develop a three-dimensional representation of velocity for the } \\
\text { repository block and surface facilities area. (FYs } 2007 \text { and 2008) }\end{array}$ & $\begin{array}{l}\text { Preclosure and } \\
\text { Postclosure }\end{array}$ & Licensing defense \\
\hline $\begin{array}{l}\text { Evaluate the sensitivity of computed ground motions to the velocity } \\
\text { profile depth at which the velocity conditions associated with the PSHA } \\
\text { reference rock outcrop }(1,900 \mathrm{~m} / \mathrm{sec} \text { ) are obtained. (FY 2006) }\end{array}$ & $\begin{array}{l}\text { Preclosure and } \\
\text { Postclosure }\end{array}$ & License application \\
\hline \multicolumn{3}{|c|}{ Update dynamic material properties for the tuff and alluvium/colluvium at Yucca Mountain: } \\
\hline $\begin{array}{l}\text { Using existing, validated models, perform numerical simulations of } \\
\text { the dynamic mechanical behavior of the tuff units overlying the } \\
\text { waste emplacement level to address their dynamic material } \\
\text { properties, including the effects of confining pressure. (FY 2006) }\end{array}$ & $\begin{array}{l}\text { Preclosure } \\
\text { Postclosure }\end{array}$ & $\begin{array}{l}\text { License Application } \\
\text { Licensing defense }\end{array}$ \\
\hline $\begin{array}{l}\text { Based on geotechnical data available in October } 2006 \text {, develop } \\
\text { updated dynamic material property curves to be used as input to } \\
\text { ground-motion site-response modeling for preclosure analyses } \\
\text { supporting the license application. (FY 2007) }\end{array}$ & Preclosure & License Application \\
\hline $\begin{array}{l}\text { Based on previous and new data from the complete set of } \\
\text { planned geotechnical investigations, update the dynamic material } \\
\text { property curves for tuff used as input to the ground-motion } \\
\text { site-response model. Develop dynamic material property curves } \\
\text { for P-wave propagation, if required by updates to the site- } \\
\text { response model. (FYs } 2007 \text { and } 2008 \text { ) }\end{array}$ & $\begin{array}{l}\text { Preclosure and } \\
\text { Postclosure }\end{array}$ & Licensing defense \\
\hline $\begin{array}{l}\text { Evaluate effects of confining pressure on dynamic material } \\
\text { property curves for alluvium. (FY 2007) }\end{array}$ & Preclosure & Licensing defense \\
\hline $\begin{array}{l}\text { Based on previous and new data from the complete set of } \\
\text { planned geotechnical investigations, update the dynamic material } \\
\text { property curves for alluvium used as input to the ground-motion } \\
\text { site-response model. Develop dynamic material property curves } \\
\text { for P-wave propagation, if required by updates to the site- } \\
\text { response model. (FYs } 2007 \text { and 2008) }\end{array}$ & Preclosure & Licensing defense \\
\hline \multicolumn{3}{|c|}{ Expand and enhance the technical basis for the validation of the ground-motion site-response model: } \\
\hline $\begin{array}{l}\text { Compare results of the ground-motion site-response model for } \\
\text { Yucca Mountain to weak-motion data recorded at the site. } \\
\text { (FY 2007) }\end{array}$ & $\begin{array}{l}\text { Preclosure and } \\
\text { Postclosure }\end{array}$ & Licensing defense \\
\hline $\begin{array}{l}\text { Compare results of the ground-motion site-response model to } \\
\text { results for fully nonlinear models for conditions at the Yucca } \\
\text { Mountain site. This comparison will be performed for } 1 \times 10^{-3}, 1 \times \\
10^{-4} \text { and } 1 \times 10^{-6} \text { annual frequency of exceedance ground motions } \\
\text { at the surface facilities area and for } 1 \times 10^{-3}, 1 \times 10^{-5} \text {, and } 1 \times 10^{-6} \\
\text { annual exceedance ground motions for the waste emplacement } \\
\text { level of the repository block. (FY } 2007 \text { ) }\end{array}$ & $\begin{array}{l}\text { Preclosure and } \\
\text { Postclosure }\end{array}$ & Licensing defense \\
\hline
\end{tabular}


Table 1. Relation of Planned Activities, Tasks, and Products to the License Application (Continued)

\begin{tabular}{|c|c|c|}
\hline Activity, Task, or Product & $\begin{array}{l}\text { Support to } \\
\text { Preclosure or } \\
\text { Postclosure } \\
\text { Analyses and } \\
\text { Modeling } \\
\end{array}$ & $\begin{array}{l}\text { Support to License } \\
\text { Application or } \\
\text { Licensing Defense }\end{array}$ \\
\hline \multicolumn{3}{|l|}{ PLANNED ACTIVITIES AND TASKS } \\
\hline $\begin{array}{l}\text { Expand and enhance the technical basis for site attenuation } \\
\text { (kappa) values used in ground motion modeling at Yucca } \\
\text { Mountain. (FY 2007) }\end{array}$ & $\begin{array}{l}\text { Preclosure and } \\
\text { Postclosure }\end{array}$ & Licensing defense \\
\hline $\begin{array}{l}\text { Compare site-response modeling results for the waste } \\
\text { emplacement level and for low annual frequencies of exceedance } \\
\text { that are determined using Approach 2B of NUREG/CR-6728 } \\
\text { (McGuire et al. } 2001 \text { [DIRS } 157510 \text { ], Section } 6.1 \text { ) to those } \\
\text { obtained using Approaches } 3 \text { and } 4 \text {. The comparison will be } \\
\text { performed for a simplified set of seismic sources. (FY 2007) }\end{array}$ & $\begin{array}{l}\text { Preclosure and } \\
\text { Postclosure }\end{array}$ & Licensing defense \\
\hline $\begin{array}{l}\text { Evaluate use of Approach } 3 \text { of NUREG/CR-6728 (McGuire et al. } \\
2001 \text { [DIRS 157510], Section 6.1) compared to Approach 2B. } \\
\text { (FYs } 2006 \text { and 2007) }\end{array}$ & $\begin{array}{l}\text { Preclosure and } \\
\text { Postclosure }\end{array}$ & Licensing defense \\
\hline $\begin{array}{l}\text { Evaluate two-dimensional effects (i.e., topography, alluvium/tuff } \\
\text { interface, velocity contrasts across Miocene faults) relative to } \\
\text { results using a one-dimensional site-response model. (FY 2007) }\end{array}$ & $\begin{array}{l}\text { Preclosure and } \\
\text { Postclosure }\end{array}$ & Licensing defense \\
\hline $\begin{array}{l}\text { Evaluate the conservatism of the current site-response approach } \\
\text { for P-wave propagation by evaluating the effect of nonlinear } \\
\text { P-wave propagation. (FYs } 2006 \text { and 2007) }\end{array}$ & $\begin{array}{l}\text { Preclosure and } \\
\text { Postclosure }\end{array}$ & Licensing defense \\
\hline $\begin{array}{l}\text { Evaluate an alternative approach to determining the } \\
\text { vertical-to-horizontal ground motion ratio for the Yucca Mountain site, } \\
\text { as a function of frequency, using a random-vibration-theory } \\
\text { (RVT)-based point-source ground motion model. (FY 2006) }\end{array}$ & $\begin{array}{l}\text { Preclosure and } \\
\text { Postclosure }\end{array}$ & Licensing defense \\
\hline \multicolumn{3}{|l|}{ Update preclosure ground motion inputs and evaluate their conservatism: } \\
\hline $\begin{array}{l}\text { Based on geotechnical data available in October 2006, recalculate } \\
\text { the ground motion inputs for the surface facilities area for annual } \\
\text { frequencies of exceedance of } 1 \times 10^{-3}, 5 \times 10^{-4} \text {, and } 1 \times 10^{-4} \text {. } \\
\text { (FY 2007) }\end{array}$ & Preclosure & License application \\
\hline $\begin{array}{l}\text { Based on geotechnical data available when all planned } \\
\text { investigations are completed, calculate the ground motion inputs } \\
\text { for the waste emplacement level and the surface facilities area for } \\
\text { annual frequencies of exceedance of } 1 \times 10^{-3}, 5 \times 10^{-4} \text {, and } 1 \times \\
10^{-4} \text {. (FYs } 2007 \text { and 2008) }\end{array}$ & Preclosure & Licensing defense \\
\hline $\begin{array}{l}\text { Update documentation of the preclosure seismic methodology in a } \\
\text { methodology report. (FY 2006) }\end{array}$ & Preclosure & License application \\
\hline $\begin{array}{l}\text { Compile and evaluate the impact of relevant new data with respect to } \\
\text { the results of the PSHA for Yucca Mountain. As appropriate, perform } \\
\text { sensitivity analyses. As required, update PSHA software qualification. } \\
\text { (FY 2007) }\end{array}$ & $\begin{array}{l}\text { Preclosure and } \\
\text { Postclosure }\end{array}$ & Licensing defense \\
\hline \multicolumn{3}{|l|}{$\begin{array}{l}\text { Develop seismic hazard curves for the surface facilities area to support } \\
\text { preclosure demonstration of performance with respect to } 10 \mathrm{CFR} 63 \\
\text { [DIRS 176544] objectives }\end{array}$} \\
\hline $\begin{array}{l}\text { Based on geotechnical data available in October 2006, develop a } \\
\text { seismic hazard curve for the surface facilities area. (FYs } 2006 \\
\text { and 2007) }\end{array}$ & Preclosure & License application \\
\hline $\begin{array}{l}\text { Based on geotechnical data available when all planned } \\
\text { investigations are completed, update the seismic hazard curve for } \\
\text { the surface facilities area. (FYs } 2007 \text { and 2008) }\end{array}$ & Preclosure & License defense \\
\hline
\end{tabular}


Table 1. Relation of Planned Activities, Tasks, and Products to the License Application (Continued)

\begin{tabular}{|c|c|c|}
\hline Activity, Task, or Product & $\begin{array}{c}\text { Support to } \\
\text { Preclosure or } \\
\text { Postclosure } \\
\text { Analyses and } \\
\text { Modeling } \\
\end{array}$ & $\begin{array}{l}\text { Support to License } \\
\text { Application or } \\
\text { Licensing Defense }\end{array}$ \\
\hline \multicolumn{3}{|l|}{ PLANNED ACTIVITIES AND TASKS } \\
\hline \multicolumn{3}{|l|}{ Update postclosure ground motion inputs and evaluate their conservatism: } \\
\hline $\begin{array}{l}\text { Expand and enhance the technical basis for a reasonable bound } \\
\text { to horizontal peak ground velocity and extend the bound to other } \\
\text { ground motion measures. (FY 2007) }\end{array}$ & $\begin{array}{l}\text { Preclosure and } \\
\text { Postclosure }\end{array}$ & Licensing defense \\
\hline $\begin{array}{l}\text { Based on information concerning the ground motions that have } \\
\text { not been experienced at Yucca Mountain during various time } \\
\text { periods, use Bayesian updating to modify mean ground motion } \\
\text { hazard curves from the PSHA. (FY 2007) }\end{array}$ & $\begin{array}{l}\text { Preclosure and } \\
\text { Postclosure }\end{array}$ & Licensing defense \\
\hline $\begin{array}{l}\text { Update time histories developed for postclosure analyses. } \\
\text { (FY 2007) }\end{array}$ & Postclosure & Licensing defense \\
\hline \multicolumn{3}{|l|}{ PLANNED PRODUCTS: } \\
\hline $\begin{array}{l}\text { Update MDL-MGR-GS-000003, Development of Earthquake Ground } \\
\text { Motion Input for Preclosure Design and Postclosure Performance } \\
\text { Assessment of a Geologic Repository at Yucca Mountain, NV (BSC } \\
2004 \text { [DIRS 170027]) to document updated preclosure ground motions } \\
\text { and seismic hazard curves for license application. (FY 2007) }\end{array}$ & Preclosure & License Application \\
\hline $\begin{array}{l}\text { Update MDL-MGR-GS-000003, Development of Earthquake Ground } \\
\text { Motion Input for Preclosure Design and Postclosure Performance } \\
\text { Assessment of a Geologic Repository at Yucca Mountain, NV } \\
\text { (BSC 2004 [DIRS 170027]) to document final seismic inputs and } \\
\text { hazard curves. (FY 2008) }\end{array}$ & $\begin{array}{l}\text { Preclosure and } \\
\text { Postclosure }\end{array}$ & Licensing defense \\
\hline $\begin{array}{l}\text { Update ANL-MGR-GS-000004, Peak Ground Velocities for Seismic } \\
\text { Events at Yucca Mountain, Nevada (BSC } 2005 \text { [DIRS 170137]). } \\
\text { (FY 2008) }\end{array}$ & Postclosure & Licensing defense \\
\hline $\begin{array}{l}\text { Prepare Geotechnical Data Supporting Seismic Analysis of Surface } \\
\text { Facilities and Aging Pad Areas for a Geologic Repository at Yucca } \\
\text { Mountain, Nevada (document Identifier to-be-determined). This new } \\
\text { report will document the acquisition of geological, geophysical, and } \\
\text { geotechnical data through the second quarter of FY } 2007 \text { to support } \\
\text { engineering calculations for potential surface facilities, aging pads and } \\
\text { ground motion modeling and analysis. It also will document basic } \\
\text { interpretations of the acquired data and present a geologic } \\
\text { interpretation with cross sections based on both the data reported } \\
\text { herein and previously acquired data. (FY 2007) }\end{array}$ & Preclosure & License Application \\
\hline $\begin{array}{l}\text { Prepare Geotechnical Data Supporting Seismic Analysis of Surface } \\
\text { Facilities and Aging Pad Areas for a Geologic Repository at Yucca } \\
\text { Mountain, Nevada (document Identifier to-be-determined). This new } \\
\text { report will document the acquisition of geological, geophysical, and } \\
\text { geotechnical data from completed planned investigations. It also will } \\
\text { document basic interpretations of the acquired data and present a } \\
\text { geologic interpretation with cross sections based on both the data } \\
\text { reported herein and previously acquired data. (FY 2008) }\end{array}$ & $\begin{array}{l}\text { Preclosure and } \\
\text { Postclosure }\end{array}$ & Licensing defense \\
\hline $\begin{array}{l}\text { Update 100-SOC-CY00-00100-000-00A, Supplemental Soils Report. } \\
\text { The existing report (BSC } 2004 \text { [DIRS } 166067 \text { ]) will be updated based } \\
\text { on the collection of additional geotechnical data. The updated report } \\
\text { will document the geological, geophysical, and geotechnical data to } \\
\text { support engineering calculations for potential surface facilities and } \\
\text { aging pads. (FY 2007) }\end{array}$ & Preclosure & Licensing defense \\
\hline
\end{tabular}


Table 1. Relation of Planned Activities, Tasks, and Products to the License Application (Continued)

\begin{tabular}{|c|c|c|}
\hline Activity, Task, or Product & $\begin{array}{c}\text { Support to } \\
\text { Preclosure or } \\
\text { Postclosure } \\
\text { Analyses and } \\
\text { Modeling } \\
\end{array}$ & $\begin{array}{l}\text { Support to License } \\
\text { Application or } \\
\text { Licensing Defense }\end{array}$ \\
\hline \multicolumn{3}{|l|}{ PLANNED ACTIVITIES AND TASKS } \\
\hline $\begin{array}{l}\text { Prepare a methodology report to update YMP/TR-003-NP, Preclosure } \\
\text { Seismic Design Methodology for a Geologic Repository at Yucca } \\
\text { Mountain (to be re-titled Preclosure Seismic Design and Performance } \\
\text { Demonstration Methodology for a Geologic Repository at Yucca } \\
\text { Mountain). The existing topical report (DOE } 2004 \text { [DIRS 172373]) will } \\
\text { be updated to describe the revised preclosure seismic methodology } \\
\text { that addresses issues raised by the January } 2006 \text { NRC letter. } \\
\text { (FY 2006) }\end{array}$ & Preclosure & License application \\
\hline $\begin{array}{l}\text { Prepare New Data and Its Impact on Results of the Probabilistic } \\
\text { Seismic Hazard Analyses for Yucca Mountain, Nevada. This new } \\
\text { report will document the results of activities to compile potentially } \\
\text { relevant data that has become available since the completion of the } \\
\text { PSHA for Yucca Mountain and evaluate their potential impact, if any, } \\
\text { on the PSHA results. (FY 2008) }\end{array}$ & $\begin{array}{l}\text { Preclosure and } \\
\text { Postclosure }\end{array}$ & Licensing defense \\
\hline
\end{tabular}

\section{Planned Activities}

- Laboratory and field testing to provide the technical basis for ground-motion site-response modeling and surface facilities foundation design

- Drill 35 boreholes (Phase 2) to further characterize the surface facilities area in the vicinity of the North Portal of the Exploratory Studies Facility (ESF) and the Aging Pad west of the Bow Ridge fault. Twenty of these boreholes will address the depth of alluvium and determination of the lithostratigraphic unit underlying the alluvium. Fourteen will be deeper, extending into the Tiva Canyon Tuff to facilitate downhole velocity measurements. One borehole will be an angled hole to investigate the characteristics of the Exile Hill splay fault. Data from these boreholes will supplement data from 16 boreholes drilled in FYs 1999 through 2001. Selection of borehole locations will consider guidance in "Site Investigations for Foundations for Nuclear Power Plants," Regulatory Guide 1.132 (NRC 2003 [DIRS 169347]). (FYs 2005, 2006, and 2007)

- Perform geologic logging of new boreholes (Phase 2) in the surface facilities area and at the Aging Pad site west of the Bow Ridge fault. (FYs 2006 and 2007)

- Perform downhole velocity surveys in 14 of the new boreholes (Phase 2). (FY 2007)

- Perform geophysical logging in 8 of the new boreholes (Phase 2). (FY 2007)

- Perform additional spectral-analysis-of-surface-wave (SASW) surveys (Phase 2). (FYs 2005 and 2006) 
- Expand characterization of the velocities of lithostratigraphic units underlying the surface facilities site, consistent with the current layout of important-tosafety facilities.

a Expand characterization of the lithostratigraphic units comprising the repository block, consistent with the current footprint of the waste emplacement area (BSC 2005 [DIRS 176805]), conducting surveys both from the surface and from within the ESF and Enhanced Characterization of the Repository Block (ECRB) Cross-Drift.

a Characterize the Aging Pad sites.

- Characterize lithostratigraphic units underlying the waste emplacement level (e.g., Calico Hills).

- Attempt to obtain hand-carved intact samples of alluvium (4-in to 6-in diameter) for laboratory dynamic testing. (FY 2006)

- Perform additional laboratory testing of dynamic material properties for existing and new samples. (FYs 2005, 2006, and 2007)

- Expand characterization of the lithostratigraphic units underlying the surface facilities site, consistent with the current layout of important-to-safety facilities.

- Expand characterization of the lithostratigraphic units comprising the repository block, including the range of units tested.

- Test 4-in and 6-in diameter tuff and alluvium samples to study sample size effects (i.e., effects of fractures in the tuff and grain size in the alluvium). (FYs 2006 and 2007)

- Evaluate potential techniques for carrying out in situ testing of alluvium dynamic properties and, if warranted, implement in situ testing techniques at up to 10 representative locations in the surface facilities area. (FY 2006)

- Perform laboratory testing of the alluvium samples to determine static properties, including density, moisture content, and compaction. (FY 2006)

- Submit new data to the Technical Data Management System (TDMS), supplementing or superseding existing data, as appropriate. Perform an impact review to evaluate the impact of the new data on existing analyses and modeling. (FYs 2006 and 2007)

- Drill 44 additional boreholes (Phase 3) to determine the depth of alluvium and geology in the vicinity of new areas where facilities will be sited to implement an approach that involves receipt of waste at Yucca Mountain that is mostly contained in multipurpose transportable, ageable, and disposable (TAD) canisters. These boreholes will consist of both shallow and deeper holes to investigate the depth of 
alluvium and underlying geology and to facilitate downhole velocity surveys, respectively. Data from these boreholes will supplement data from the 16 drilled in FYs 1999 through 2001 and the 35 drilled in FYs 2005 through 2007. (FYs 2007 and 2008)

- Perform geophysical logging and downhole seismic surveys in the additional new deeper boreholes (Phase 3). (FY 2007)

- Excavate and log trenches and test pits to describe and evaluate site materials and confirm the absence of active faulting. This work will include a trench in the vicinity of the Initial Handling Facility. Results of the PSHA (BSC 2004 [DIRS 168030], Section 6.6.3) and available geologic information indicate that the likelihood of active faulting is very low, except at block-bounding faults such as the Bow Ridge and Paintbrush Canyon faults. (FY 2007)

- Perform additional SASW surveys (Phase 3) to extend the spatial coverage of velocity surveys to include new areas where facilities will be sited. (FY 2007)

- Submit additional data (Phase 3) to the TDMS. Perform an impact review to evaluate the impact of the new data on existing analyses and modeling. (FYs 2007 and 2008)

- Confirm through field investigations and other analyses that pervasive, seismic-related, inter-lithophysal fractures are not observed in the ESF and ECRB Cross-Drift. (FY 2006)

- Periodically evaluate geotechnical data collected after October 2006 to determine that new data are consistent with existing interpretations and conclusions. If new data indicate that existing interpretations and conclusions are not confirmed, initiate a CR.

- Update velocity profiles for the repository block and surface facilities area.

- Evaluate the correlation between velocity layering and lithostratigraphic contacts and/or properties. To support this effort, develop a three-dimensional representation of the geology beneath the surface facilities area. (FYs 2006, 2007 and 2008)

- Reconcile, if possible, velocity data collected by different techniques. (FYs 2006 and 2007)

- Based on geotechnical data available in October 2006, develop updated velocity profiles to be used as input to ground-motion site-response modeling for preclosure analyses supporting the license application. (FY 2007)

- Based on previous and new data from the complete set of planned geotechnical investigations, update velocity profiles for the repository block and surface facilities area. (FYs 2007 and 2008) 
- Based on previous and new data from the complete set of planned geotechnical investigations, update the analysis of correlation between velocity and layer thickness as a function of depth for the repository block and surface facilities area. (FYs 2007 and 2008)

- Develop a three-dimensional representation of velocity for the repository block and surface facilities area. (FYs 2007 and 2008)

- Evaluate the sensitivity of computed ground motions to the velocity profile depth at which the velocity conditions associated with the PSHA reference rock outcrop $(1,900 \mathrm{~m} / \mathrm{sec})$ are obtained and the velocity at the repository level. (FY 2006)

- Submit new data to the TDMS. Perform an impact review to evaluate the impact of the new data on existing analyses and modeling. (FYs 2007 and 2008)

- Update dynamic material properties for the tuff and alluvium/colluvium at Yucca Mountain.

- Using existing, validated models, perform numerical simulations of the dynamic mechanical behavior of the tuff units overlying the waste emplacement level to address their dynamic material properties, including the effects of confining pressure. (FY 2006)

- Based on geotechnical data available in October 2006, develop updated dynamic material property curves to be used as input to ground-motion site-response modeling for preclosure analyses supporting the license application. (FY 2007)

- Based on previous and new data from the complete set of planned geotechnical investigations, update the dynamic material property curves for tuff used as input to the ground-motion site-response model. Develop dynamic material property curves for P-wave propagation, if required by updates to the site-response model. (FYs 2007 and 2008)

- Evaluate effects of confining pressure on dynamic material property curves for alluvium. (FY 2007)

- Based on previous and new data from the complete set of planned geotechnical investigations, update the dynamic material property curves for alluvium used as input to the ground-motion site-response model. Develop dynamic material property curves for $\mathrm{P}$-wave propagation, if required by updates to the site-response model. (FYs 2007 and 2008)

- Submit new data to the TDMS. Perform an impact review to evaluate the impact of the new data on existing analyses and modeling. (FYs 2007 and 2008) 
- Expand and enhance the technical basis for the validation of the ground-motion site-response model

- Compare results of the ground-motion site-response model for Yucca Mountain to weak-motion data recorded at the site. (FY 2007)

- Compare results of the ground-motion site-response model to results for fully nonlinear models for conditions at the Yucca Mountain site. This comparison will be performed for $1 \times 10^{-3}, 1 \times 10^{-4}$, and $1 \times 10^{-6}$ annual frequency of exceedance ground motions at the surface facilities area and for $1 \times 10^{-3}, 1 \times 10^{-5}$, and $1 \times 10^{-6}$ annual exceedance ground motions for the waste emplacement level of the repository block. (FY 2007)

- Expand and enhance the technical basis for site attenuation (kappa) values used in ground motion modeling at Yucca Mountain. (FY 2007)

- Compare site-response modeling results for the waste emplacement level and for low annual frequencies of exceedance that are determined using Approach $2 \mathrm{~B}$ of NUREG/CR-6728 (McGuire et al. 2001 [DIRS 157510], Section 6.1) to those obtained using Approaches 3 and 4 . The comparison will be performed for a simplified set of seismic sources. (FY 2007)

- Evaluate use of Approach 3 of NUREG/CR-6728 (McGuire et al. 2001 [DIRS 157510], Section 6.1) compared to Approach 2B. (FYs 2006 and 2007)

- Evaluate two-dimensional effects (i.e., topography, alluvium/tuff interface, velocity contrasts across Miocene faults) relative to results using a one-dimensional site-response model. (FY 2007)

- Evaluate the conservatism of the current site-response approach for P-wave propagation by evaluating the effect of nonlinear P-wave propagation. (FYs 2006 and 2007)

- Evaluate an alternative approach to determining the vertical-to-horizontal ground motion ratio for the Yucca Mountain site, as a function of frequency, using a random-vibration-theory (RVT)-based point-source ground motion model. (FY 2006)

- Update preclosure ground motion inputs and evaluate their conservatism

- Based on geotechnical data available in October 2006, recalculate the ground motion inputs for the surface facilities area for annual frequencies of exceedance of $1 \times 10^{-3}, 5 \times 10^{-4}$, and $1 \times 10^{-4}$. Calculate results for a range of response spectra damping values. In addition, calculate the strain-compatible soil properties. Use updated velocity profiles, dynamic material property curves, and model/analysis approach, as appropriate. (FY 2007) 
- Based on geotechnical data available when all planned investigations are completed, calculate the ground motion inputs for the waste emplacement level and the surface facilities area for annual frequencies of exceedance of $1 \times 10^{-3}, 5 \times 10^{-4}$, and $1 \times 10^{-4}$. Calculate results for a range of response spectra damping values. Also recalculate the peak ground motion values, strains, and curvatures as a function of depth for the repository block. For the surface facilities area, also calculate the strain-compatible soil properties. Use updated velocity profiles, dynamic material property curves, and model/analysis approach, as appropriate. (FY 2008)

- Submit new data to the TDMS. Perform an impact review to evaluate the impact of the new data on existing analyses and modeling. (FYs 2007 and 2008)

- Update documentation of the preclosure seismic methodology in a methodology report. (FY 2006)

- Compile and evaluate the impact of relevant new data with respect to the results of the PSHA for Yucca Mountain. As appropriate, perform sensitivity analyses. As required, update PSHA software qualification. (FY 2007)

- Develop seismic hazard curves for the surface facilities area to support preclosure demonstration of performance with respect to 10 CFR 63 [DIRS 176544] objectives

- Based on geotechnical data available in October 2006, develop a seismic hazard curve for the surface facilities area to support probabilistic analyses needed to demonstrate compliance with 10 CFR 63 [DIRS 176544]. Use Approach 3 of NUREG-6728 (McGuire et al. 2001 [DIRS 157510], Section 6.1) to obtain a mean hazard curve. Qualify software to implement Approach 3. As appropriate, incorporate limits to extreme ground motion at Yucca Mountain in developing the hazard curve for low annual exceedance probabilities. Submit data to the TDMS. (FYs 2006 and 2007)

- Based on geotechnical data available when all planned investigations are completed, update the seismic hazard curve for the surface facilities area. (FYs 2007 and 2008)

- Update postclosure ground motion inputs and evaluate their conservatism

- Expand and enhance the technical basis for a reasonable bound to horizontal peak ground velocity and extend the bound to other ground motion measures. (FY 2007)

- Update numerical modeling of lithophysal tuff deformation to reflect new information, if any, on tuff properties and to include preexisting fractures.

- Based on available data, update the probability distribution for the shear-strain increment threshold corresponding to the development of pervasive interlithophysal fracturing. 
- Expand analysis of site-response modeling to determine a 5\%-damped response spectrum corresponding to dynamic shear strains at the depth of lithophysal tuffs that would cause pervasive interlithophysal fracturing.

- Perform scenario earthquake ground motion modeling to address the probability associated with extreme ground motion at Yucca Mountain. Use both point-source and finite-source models. Document validation of the point-source and finite-source ground motion models if results are used for quality-affecting work. Qualify software for the finite-source ground motion model and stress drop inversions.

- Based on information concerning the ground motions that have not been experienced at Yucca Mountain during various time periods, use Bayesian updating to modify mean ground motion hazard curves from the PSHA. (FY 2007)

- Update time histories developed for postclosure analyses. (FY 2007)

a Characterize the fractile level of seismograms in the strong ground motion database with respect to ground motion attenuation relationships.

a Characterize the correlation between ground motion measures for seismograms in the strong ground motion database.

a Evaluate the correlation of intensity measures other than peak ground velocity with engineered barrier system (EBS) damage for postclosure structural response analyses.

a Develop and evaluate alternate approaches for determining time histories for postclosure analyses that take into account a reasonable bound to ground motion at Yucca Mountain.

- Develop time histories with annual frequencies of exceedance less than $1 \times 10^{-4}$. Compare to those previously used in postclosure analyses.

a Update the ground motion hazard curve for the waste emplacement level for an appropriate ground motion measure(s).

- Submit new data to the TDMS. Perform an impact review to evaluate the impact of the new data on existing analyses and modeling. (FY 2007) 


\section{Confirmatory Activities}

As summarized in Table 1 and described above, a number of planned activities will not directly support the LA, but are expected to confirm or enhance the technical basis for results directly supporting the LA. These results will be used to address any Requests for Additional Information from the NRC and in licensing defense. The bases for anticipating confirmatory results are discussed below:

- Trenches to investigate potential Quaternary-age surface faulting in the vicinity of the Initial Handling Facility are anticipated to confirm the absence of faulting. Results from an earlier trench extending from the vicinity of the North Portal eastward into Midway Valley (Swan et al. 2001 [DIRS 158784]) imply the absence of any appreciable late Quaternary faulting at that location. Also, the probabilistic fault displacement hazard analysis for Yucca Mountain (BSC 2004 [DIRS 168030]) determined that, for a fracture in Midway Valley with no measurable displacement in Quaternary alluvium, the fault displacement with a $1 \times 10^{-6}$ annual probability of exceedance is small $(11 \mathrm{~cm})$.

- Additional study of fractures in the ESF and ECRB and from boreholes is anticipated to confirm the lack of fractures exhibiting characteristics that would point to past extreme ground motion at Yucca Mountain. Existing data show the majority of fractures are associated with the tuff cooling process, with most others having an indeterminate origin. The distribution of fractures with indeterminate origin among those with a clear cooling origin, and modeling results that indicate fractures related to extreme ground motion should be spatially widespread, lead to the anticipation that new results will allow additional fractures to moved from the "indeterminate" to the "cooling" category.

- Preclosure ground motions for design and safety analyses supporting the LA will be based on geotechnical information available in October 2006. Additional geotechnical data will be collected after October 2006 to confirm the inputs to seismic site-response modeling. Based on the general understanding of the geologic structure of Midway Valley, the more detailed geologic data in the vicinity of the surface facilities area, and the observed variability of geotechnical data collected to date, it is anticipated that data collected after October 2006 will be consistent with the velocity profiles and dynamic material property curves developed in October 2006. The additional data will provide more-robust spatial coverage for velocity data and more information on sample size effects for dynamic material property data.

- Postclosure ground motions used in postclosure analyses are based on geotechnical data available in 2002 (BSC 2004 [DIRS 170027], Section 6.2). Updated ground motions based on updated site-response model inputs are anticipated to show that the ground motions used in analyses supporting the LA are adequate or conservative. Such a result is anticipated because development of the current set of time histories used for postclosure analyses did not take into account data that lead to a conclusion that extreme ground motions at Yucca Mountain can be reasonably bounded. 
- Activities to enhance the technical basis for validation of the Yucca Mountain ground motion site-response model are anticipated to confirm the model validation documented in MDL-MGR-GS-000003 Rev 01 (BSC 2004 [DIRS 170027]).

- Model results are anticipated to compare favorably to weak motion data recorded at Yucca Mountain because the model is well validated for typical ground motion levels and model inputs are based on site-specific data.

- Model results for Yucca Mountain-specific conditions are anticipated to compare favorably to those using nonlinear models because favorably comparisons have been observed at other sites for a range of conditions and ground motion levels.

- Site-response modeling results for the waste emplacement level and for low annual frequencies of exceedance that are determined using Approach 2B of NUREG/CR-6728 (McGuire et al. 2001 [DIRS 157510], Section 6.1) are anticipated to compare favorably to those obtained using Approach 3 because scoping studies have indicated that results using Approach 2B are conservative relative to those using Approach 3 at Yucca Mountain.

- Evaluation of two-dimensional site-response effects is anticipated to show insignificant differences relative to results using a one-dimensional model because the empirical database of ground motions used to define ground motion attenuation relationships includes data from sites with two- and three-dimensional effects.

\section{$\underline{\text { Products }}$}

In addition to the planned products described below, revisions or administrative changes to existing documents will be performed, as needed, to address issues identified in condition reports.

- MDL-MGR-GS-000003, Development of Earthquake Ground Motion Input for Preclosure Design and Postclosure Performance Assessment of a Geologic Repository at Yucca Mountain. This existing report (BSC 2004 [DIRS 170027]) will be updated to include new information on inputs to the ground-motion site-response model, recalculated seismic inputs, seismic hazard curves for the surface facility area, validation of the point-source and finite-source ground motion models, and discussion of work to expand and enhance the technical basis for validation of the site-response model. Discussion of activities to expand and enhance the technical basis for validation of the site-response model beyond the procedurally required level of confidence will be clearly delineated within the report (e.g., documented in a report appendix).

Two revisions are planned. The first (FY 2007) will document updated ground motions for design and preclosure safety analyses supporting the license application. These ground motions will be developed using inputs based on geotechnical data available in October 2006. The second revision (FY 2008) will describe both updated preclosure and postclosure ground motions developed using inputs based on the complete set of 
geotechnical data from planned investigations. This revision will be used to confirm that license application inputs are adequate and conservative and for licensing defense.

- ANL-MGR-GS-000004, Peak Ground Velocities for Seismic Events at Yucca Mountain, Nevada. This existing report (BSC 2005 [DIRS 170137]) will be updated to include new information pertaining to reasonable bounds to ground motion for the waste emplacement level at Yucca Mountain. (FY 2008)

- Document Identifier to be determined, Geotechnical Data Supporting Seismic Analysis of Surface Facilities and Aging Pad Areas for a Geologic Repository at Yucca Mountain, Nevada. This new report will document the acquisition of geological, geophysical, and geotechnical data to support engineering calculations for potential surface facilities, aging pads and ground motion modeling and analysis. It also will document basic interpretations of the acquired data and present a geologic interpretation with cross sections based on both the data reported herein and previously acquired data. This report will supplement the data report, Geotechnical Data for a Potential Waste Handling Building and for Ground Motion Analysis for the Yucca Mountain Site Characterization Project, ANL-MGR-GE-000003, (BSC 2002 [DIRS 157829]), which documents the testing performed in the area of the north portal facilities in FYs 2001 and 2002. (FY 2007)

Two versions are planned. The first (FY 2007) will document new geotechnical data collected through the second quarter of FY 2007. The second version (FY 2008) will describe the complete set of geotechnical data from planned investigations.

- 100-S0C-CY00-00100-000-00A, Supplemental Soils Report. The existing report (BSC 2004. [DIRS 166067]) will be updated based on the collection of additional geotechnical data. The updated report will document the geological, geophysical, and geotechnical data to support engineering calculations for potential surface facilities and aging pads. (FY 2007)

- YMP/TR-003-NP, Preclosure Seismic Design Methodology for a Geologic Repository at Yucca Mountain (to be retitled Preclosure Seismic Design and Performance Demonstration Methodology for a Geologic Repository at Yucca Mountain). The existing topical report (DOE 2004 [DIRS 172373]) will be updated, using PA-PRO0313, by a report to describe a preclosure seismic design and performance demonstration methodology that addresses issues raised by Kokajko (2006 [DIRS 176995]) and Draft Interim Staff Guidance Document HLWRS-ISG-01 (71 FR 29369 [DIRS 177351]).

- Document-Identifier to-be-determined, New Data and Its Impact on Results of the Probabilistic Seismic Hazard Analyses for Yucca Mountain, Nevada. This new report will document the results of activities to compile potentially relevant data that has become available since the completion of the PSHA for Yucca Mountain and evaluate their potential impact, if any, on the PSHA results. (FYs 2007 and 2008)

- Various scientific notebooks may be used to document testing, analyses, and modeling activities. 
Description of Scoping Activities

Scoping activities may be used to explore alternative approaches in carrying out testing, analyses, and modeling. Any scoping activities that are performed will be controlled in accordance with LP-SIII.9Q-BSC, LP-SIII.10Q-BSC, and LP-SIII.11Q-BSC, with the exception that unqualified data and unqualified software may be used. If it is determined that scoping activities should be carried forward into the technical product, it will be demonstrated that the work was performed consistent with the controls for quality-affecting work or work will be repeated in accordance with applicable implementing procedures. If unqualified software or data were used that need to be carried forward, qualification will be performed and software runs repeated.

Scoping activities are planned as part of the effort to implement Approach 3 of NUREG/CR-6728 (McGuire et al. 2001 [DIRS 157510], Section 6.1). One scoping activity .will be performed to compare Approach 3 with Approach 2B, which was used to develop previous ground motion inputs. For this scoping activity, mean seismic hazard curves will be developed using the same inputs to the site-response model as was done previously to examine the effect of changing only the approach. A second scoping activity will implement Approach 3 with updated inputs to the site-response model to examine combined effects. For this scoping activity, unqualified data may be used and some unqualified software will be used. Once the method to implement Approach 3 is finalized, calculations will be performed as quality-affecting work.

\section{Related Work Described in Other Technical Work Plans}

In addition to the work described in this TWP, different TWPs describe other components of the overall seismic program. Work to evaluate the seismic response of EBS components during the postclosure period and abstraction of those results for the total system performance assessment (TSPA) are planned in TWP-MGR-GS-000004 (Technical Work Plan for: Calculation of Waste Package and Drip Shield Response to Vibratory Ground Motion and Revision of the Seismic Consequence Abstraction). Work to examine the effects of extreme ground motion from underground nuclear explosions on tuffs at the Nevada Test Site and to evaluate how such data may be used to bound ground motions experienced at Yucca Mountain is planned in TWP-MGRGS-000006 (Technical Work Plan for: Conducting Field Studies to Support Constraints on Extreme Ground Motion). Work to examine the age of the alluvium beneath the surface facilities area through dating pedogenic calcite and opal is planned in TWP-MGR-GS-000005 (Technical Work Plan for: Age Constraints on Faulting Below the Surface Facilities Area). Given that the alluvium is not faulted, this work will provide some constraint on the period of time over which surface faulting has not occurred at that site.

\subsection{RESPONSIBLE ORGANIZATIONS FOR WORK AND PRODUCTS}

The Postclosure Activities (PCA) organization of Bechtel SAIC Company, LLC (BSC) is responsible for the overall work effort. Within PCA, the organization responsible for this work effort is the Disruptive Events department. It is anticipated that technical services and staff augmentation subcontractors will be required to support the work. Testing work will be performed under auspices of the Test Coordination Office. In addition, the U.S. Geological Survey (USGS) will provide support to the activity to develop a reasonable bound to ground 
motions for the emplacement level at Yucca Mountain. The U.S. Bureau of Reclamation (BOR), working under the auspices of the USGS, also will provide support, including planning for the field testing activities, development of borehole logs, cataloging of core samples in support of the Sample Management Facility, mapping and analysis of underlying geology, and study of test pits. The BOR will also provide, in accordance with YMP procedures, laboratory static testing in their Denver, Colorado laboratory on selected alluvium samples.

\subsection{PRETEST PREDICTIONS}

No formal pretest predictions are planned. Results of the new testing will be combined with previously acquired data and used to determine updated mean values and variability for velocity and dynamic material properties of site materials. Testing results available in October 2006 will be used to define velocity profiles and dynamic material property curves that will be used in siteresponse modeling that supports development of seismic inputs for preclosure design and safety analyses supporting the license application. When geotechnical investigations are complete in FY 2008, velocity profiles and dynamic material property curves will be reviewed in light of all available data and updated again, if appropriate. These final inputs to the site-response model will then be used to develop final ground motions for Yucca Mountain. Evaluations will then be performed confirm results presented in the license application (or assess impacts, if any) and to assess conservatism in previous results for licensing defense.

Geologic data obtained from drilling and trenching tests will be used to update and extend the geologic interpretation of the surface facilities area. Results are expected to be generally consistent with the geologic interpretations of Geologic Map of the Yucca Mountain Region, Nye County, Nevada (Potter et al. 2002 [DIRS 160060]), but to allow a more detailed understanding of the geologic units and structure directly underlying the surface facilities area. Differences between current and updated geologic interpretations will be reviewed for any impact on existing analyses and modeling. Specifically, as geologic data are obtained throughout FYs 2007 and into 2008, the thickness of alluvium beneath sites of important-to-safety surface facilities will be checked to confirm the range of alluvium thickness used in site-response modeling for preclosure ground motions. This range will be defined based on data available in November 2006 . If alluvium thickness values are observed that are about $20 \mathrm{ft}$ or more greater than those used in modeling, additional site-response modeling and ground motion development may be needed.

\section{SCIENTIFIC APPROACH OR TECHNICAL METHODS}

This section describes the scientific approach or technical methods planned to perform the activities and tasks and to produce the products described in Section 1.2. Some of the tasks involve modeling and scientific analyses. For these tasks, model use and model validation issues are addressed.

\subsection{INTENDED USE AND PURPOSE}

Seismic ground motion inputs are used in preclosure design and probabilistic safety analyses and in analyses to determine the structural response of engineered barrier system components during the postclosure period. Ground motion inputs for use in such analyses have previously been developed and are documented in Development of Earthquake Ground Motion Input for 
Preclosure Seismic Design and Postclosure Performance Assessment of a Geologic Repository at Yucca Mountain, NV (BSC 2004 [DIRS 170027]). Work scope described in this TWP is planned to update the previous inputs. For the preclosure period, updated ground motion results based on geotechnical data available in October 2006 will be used in design and safety analyses that will support the license application. Final updated ground motion results based on data from the full set of planned geotechnical investigations will be completed in FY 2008 and will be used to confirm the previous results and in licensing defense. For the postclosure period, the previously developed ground motions will be used in analyses supporting the license application (BSC 2006'[DIRS 177243]). Updated postclosure ground motions will be used in licensing defense to demonstrate that previously used ground motions are adequate or conservative.

The work scope also includes tasks to expand the technical basis for the model validation for use during the license application defense process. This work enhances previous work that validated the site-response model to the procedurally required level of confidence. Finally, the work scope includes tasks to strengthen the technical basis for determining a reasonable bound to ground motion at Yucca Mountain. A bounded ground motion hazard curve serves as an input to the seismic consequence abstraction. These results will also be used in licensing defense.

In addition to the work scope updating ground motions for preclosure design analyses, two other planned activities support analyses and products that will be described in the license application:

- Prepare a methodology report describing the preclosure seismic design methodology, including the approach to demonstration of compliance with preclosure performance objectives in 10 CFR 63 [DIRS 176544]

- Develop a mean seismic hazard curve for the surface facilities area that will be appropriate for use in preclosure probabilistic analyses

These activities respond to issues identified by the NRC in their letter to the DOE on preclosure seismic design methodology and performance demonstration (Kokajko 2006 [DIRS 176995]).

Seismic ground motion inputs for preclosure analyses are developed for two locations (BSC 2004 [DIRS 170027], Section 6.3): a rock interface at the depth of the potential waste emplacement drifts and a surface site with varying soil depth (alluvium/colluvium) overlying tuff (i.e., the site of repository surface facilities). The inputs consist of acceleration response spectra at multiple damping levels for horizontal and vertical components of ground motion for DBGM1, DBGM-2, and Beyond Design Basis Ground Motion (DOE 2004 [DIRS 172373]). These ground motion inputs correspond to mean hazard annual exceedance frequencies of $1 \times 10^{-3}, 5 \times$ $10^{-4}$, and $1 \times 10^{-4}$, respectively. Time histories (synthetic seismograms) also are developed, consistent with the 5\%-damped response spectra. Three-dimensional dynamic strains and curvatures, peak ground acceleration, and peak ground velocity as a function of depth between the surface and the potential waste emplacement level are calculated. In addition, strain-compatible soil properties are developed for the soil site. The customer for the first round of updated preclosure seismic inputs resulting from the work described in this TWP, based on geotechnical data available in October 2006, is the Repository Project Management (RPM) Engineering organization. Customers for the final round of updated seismic inputs, based on 
geotechnical data from all planned investigations, are the RPM Engineering and Licensing organizations.

In support of preclosure safety analyses, seismic hazard curves will be developed for the surface facilities area. A first round of hazard curves will be developed based on geotechnical data available in October 2006. The Preclosure Safety Analyses department will use these results in assessing the preclosure safety of the repository for the license application. A second round of hazard curves will be developed based on the final set of geotechnical data when the planned investigations are complete. The second round of hazard curves will be used by the Licensing department to confirm the previous results and in licensing defense.

In support of postclosure analyses, time histories were previously developed for a rock interface at the waste emplacement level (BSC 2004 [DIRS 170027], Section 6.3). For annual exceedance frequencies of $1 \times 10^{-5}, 1 \times 10^{-6}$, and $1 \times 10^{-7}, 17$ sets of three-component time histories were developed consistent with the site-specific horizontal peak ground velocity. The customer for these previously developed seismic inputs is the Disruptive Events department. The inputs were used in previous seismic structural response calculations for EBS components and in rockfall modeling and analyses (e.g., BSC 2004 [DIRS 171717]; 2004 [DIRS 166107]); 2004 [DIRS 172448]; 2004 [DIRS 167083]). The same seismic inputs will be used for updated postclosure seismic structural response calculations supporting the license application (BSC 2006 [DIRS 177243]). Work described in this TWP will result in updated postclosure seismic inputs. The customer for these updated seismic inputs is the Licensing organization, which will use them in licensing defense to compare unbounded ground motions used in license application analyses to those that incorporate a reasonable bound based on site-specific data and confirm that license application analyses are adequate or conservative.

Also, in support of postclosure analyses, a reasonable bound to ground motion at the waste emplacement level was previously determined. This bound was combined with a seismic hazard curve for the waste emplacement level to obtain a bounded hazard curve (BSC 2005 [DIRS 170137], Section 6.8). The customer for this result is the Disruptive Events department, which uses it in the seismic consequence abstraction (BSC 2004 [DIRS 169183]). The customer for the results of work described in this TWP to enhance the technical basis for the bound is the Licensing organization, which will use them in licensing defense.

Results of laboratory and field testing will be used by the Disruptive Events department, the RPM Engineering organization, and the Licensing organization, as follows:

- Results of drilling and geologic logging of new boreholes at the surface facilities area will be used by the Disruptive Events department to expand the detailed three-dimensional representation of the site's underlying geology. Results available in October 2006 will be used to determine the geologic structure and alluvium thickness for site-response modeling to develop ground motions used for preclosure design and safety analyses. Results available when the geotechnical investigations are completed in FY 2008 will be used to confirm the geologic structure and range of alluvium thickness previously used in developing ground motion inputs for the license application. 
Available results will also be used by the Disruptive Events department to define the geologic structure and range of alluvium thickness to be considered in the analysis to determine a mean hazard curve for the surface facilities area. Hazard curves based on data available in October 2006 will be used by the Preclosure Safety Analyses organization in the preclosure safety analysis that will be described in the LA. Hazard curves based on the complete data set from planned geotechnical investigations will be used by the Licensing organization to confirm the previous results are adequate or conservative and in licensing defense.

Test requirements and instructions for borehole drilling are documented in Repository Facilities Geotechnical Investigations (ORD 2004 [DIRS 173744]) (FWP-SBT-PA-000005).

- Results of SASW and borehole velocity surveys are intended for use by the Disruptive Events department to develop velocity profiles used in site-response modeling by increasing the amount of data available for the current extent of the surface facilities area. The results also are used to assess the uncertainty that should be included in velocity profiles used for future site-response modeling. Further, the results will contribute to developing a three-dimensional velocity model for the repository block and the surface facilities area. Velocity data available in October 2006 will be used to update ground motions for preclosure design and safety analyses supporting the license application. Data available when the complete set of surveys is completed in FY 2007 will be used to confirm velocity profiles and update ground motions for licensing defense.

Test requirements and instructions for SASW surveys are documented in SASW Investigations for Repository Facilities (ORD 2004 [DIRS 173745]) (FWP-SBT-PA-000003). Test requirements and instructions for borehole velocity surveys will be documented in a field work package in accordance with PA-PRO-0308.

- Results of geophysical logging in the new boreholes is intended to provide information that will be used by the Disruptive Events organization to evaluate the correlation between seismic velocity layering, lithostratigraphic unit contacts, and other rock mechanical properties. These results support confirmation of a geologic model and velocity profiles for the surface facilities area. Test requirements and instructions for geophysical logging are documented in Surface-Based Borehole Instrumentation and Monitoring (YMP 1999 [DIRS 150629]) (FWP-SB-97-009).

- Results of laboratory static testing of samples from the new boreholes will be used by the RPM Engineering organization to support foundation design of repository surface facilities. Testing will be performed in accordance with American Society for Testing Materials (ASTM) standards as documented in PA-PRO-0309, Laboratory Geotechnical Testing of Soil, Rock, and Aggregate Samples.

- Results of laboratory dynamic testing of samples from new and existing boreholes and from other sources are intended for use by the Disruptive Events department to develop dynamic material property curves for tuff and alluvium. Results of in situ testing of 
alluvium, if deemed feasible and implemented, also support this goal. The results also provide the basis for assessing uncertainties in dynamic material property curves used in future site-response modeling. Results available in October 2006 will be used in developing updated ground motions for preclosure design and safety analyses described in the license application. Results available when the geotechnical investigations are completed in FY 2008 will be used in confirming preclosure and postclosure ground motions for licensing defense.

Testing of tuff and alluvium samples is planned. Testing will be performed in accordance with PA-PRO-0309 and PA-PRO-0310.

- Geologic studies of fractures observed in underground excavations are intended to be used by the Disruptive Events department to enhance the technical basis for a reasonable bound to ground motion at the waste emplacement level beneath Yucca Mountain. Test requirements and instructions are documented in Geologic Mapping (ORD 2003 [DIRS 170203]) (FWP-ESF-PA-001).

As indicated above, a number of activities and tasks described in this TWP provide results that are intended to confirm license application results and for use in licensing defense. These results will become available after analyses and modeling that supports the license application have been completed. While it is anticipated that results for licensing defense will confirm that results used in the license application are adequate or conservative, there is some potential that they will indicate licensing inputs are unconservative. Thus, it is planned to evaluate results obtained for licensing defense in terms of their impact on the license application. Impacts of new data, results, or approaches will be evaluated through sensitivity analyses that determine how ground motions and soil properties are changed. Response spectra changes less than about $15 \%$ to $20 \%$ are not expected to have significant impact on design or performance analyses. In the case in which licensing defense data are being submitted to the TDMS, superseding existing data, APSIII.3Q requires that an impact review be performed by any users of the superseded data. The outcome of an impact review is documented on an Impact Review Action Notice form and, if necessary, includes a description of additional work that may be required if the impact is not negligible. In the case of analysis and modeling work, impacts will be evaluated in the report documenting the work. If at any point in the analysis and modeling process it is determined that licensing results are unconservative, a CR will be initiated in accordance with AP-16.1Q, Condition Reporting and Resolution. For data collection activities, evaluations of new data will be documented in scientific notebooks. If new data are determined to be unexpected, unanticipated test conditions are encountered, or an off-normal event occurs, the responsible manager will be notified. If appropriate, a CR will be prepared and actions to investigate the condition and determine its impact will be planned and performed in accordance with AP-16.1Q. If warranted, action will be taken in accordance with AP-REG-009, Reportable Geologic Conditions.

Work described in this TWP does not directly address any seismic-related features, events, and processes relevant to postclosure performance. Indirectly, however, it provides ground motion results that are used in assessing the seismic response of EBS components during the postclosure period as described in Technical Work Plan for: Calculation of Waste Package and Drip Shield Response to Vibratory Ground Motion and Revision of the Seismic Consequence Abstraction 
(BSC 2006 [DIRS 177243]) (TWP-MGR-GS-000004 REV 01). Seismic-related features, events, and processes are documented in Features, Events, and Processes: Disruptive Events (BSC 2005 [DIRS 173981]) (ANL-WIS-MD-000005 REV 03) and are summarized in Table 2.

Table 2. Seismic-related Features, Events, and Processes

\begin{tabular}{|l|l|}
\hline \multicolumn{1}{|c|}{ Identification Number } & \multicolumn{1}{c|}{ Description } \\
\hline $1 \cdot 2.01 .01 .0 \mathrm{~A}$ & Tectonic Activity-large scale \\
\hline $1.2 .02 .03 .0 \mathrm{~A}$ & Fault displacement damages EBS components \\
\hline $1.2 .03 .02 .0 \mathrm{~A}$ & Seismic ground motion damages EBS components \\
\hline $1.2 .03 .02 .0 \mathrm{~B}$ & Seismic-induced rockfall damages EBS components \\
\hline $1.2 .03 .02 .0 \mathrm{C}$ & Seismic-induced drift collapse damages EBS components \\
\hline $1.2 .03 .02 .0 \mathrm{D}$ & Seismic-induced drift collapse alters in-drift thermohydrology \\
\hline $1 \cdot 2.03 .03 .0 \mathrm{~A}$ & Seismicity associated with igneous activity \\
\hline $1.2 .10 .01 .0 \mathrm{~A}$ & Hydrologic response to seismic activity \\
\hline $2.2 .06 .01 .0 \mathrm{~A}$ & Seismic activity changes porosity and permeability of rock \\
\hline $2.2 .06 .02 .0 \mathrm{~A}$ & Seismic activity changes porosity and permeability of faults \\
\hline $2 \cdot 2.06 .02 .0 \mathrm{~B}$ & Seismic activity changes porosity and permeability of fractures \\
\hline $2.2 .06 .03 .0 \mathrm{~A}$ & Seismic activity alters perched water zones \\
\hline
\end{tabular}

Source: BSC 2005 [DIRS 173981], Table 1-1.

\subsection{APPROACH AND METHODS}

\subsubsection{Field and Laboratory Testing}

Field and laboratory testing activities are planned to provide data that will be used to update inputs to the ground-motion site-response model and to strengthen the technical basis for establishing a reasonable bound to ground motion at Yucca Mountain. The scientific approach and technical methods employed in these testing activities are the same as used in past testing programs (BSC 2002 [DIRS 157829]). A combination of drilling, geological and geophysical logging, SASW surveys, and laboratory testing of material static and dynamic properties provide the needed information. If not already in place (see Section 2.1), Field Work Packages for the field component of this work will be developed in accordance with PA-PRO-0308. Data, analyses, and results will be recorded in scientific notebooks or as identified in applicable technical procedures. Data will be submitted to the TDMS in accordance with AP-SIII.3Q, Submittal and Incorporation of Data to the Technical Data Management System.

\section{Geologic Data}

Boreholes provide information on subsurface geology at a particular point. If cored, they also provide samples of subsurface material. Geological logging of core or borehole cuttings will provide the geologic interpretation of the material penetrated by each borehole. Video and geophysical logging (e.g., density, resistivity) will provide information on the physical properties of the material encountered. Standard geologic principles will then be used to integrate the borehole data along with other available data to develop a three-dimensional representation of the subsurface geology for the site being characterized. 
Geologic conditions are expected to be generally consistent with the geologic interpretation of Potter et al. (2002 [DIRS 160060]) for Midway Valley. That is, drilling is expected to penetrate alluvium that increases in thickness towards the center of the valley and then encounter the Tiva Canyon Tuff or post-Tiva Canyon tuffs. The tuff underlying the alluvium is expected to be characterized by Miocene-age intrablock faults with offsets up to several hundred feet, consistent with those observed elsewhere at Yucca Mountain. Evidence for faulting of the overlying alluvium is not expected, except near mapped faults with Quaternary-age offset (i.e., the Bow Ridge fault, the Paintbrush Canyon fault). Conditions that differ from those described would be considered unexpected. If unexpected results, unexpected test conditions, or off-normal events are encountered, they will be handled as described in Section 2.1.

\section{Velocity Data}

To obtain data needed to characterize the velocities of subsurface materials, two approaches are used. First, downhole seismic surveys are performed in available boreholes. These surveys provide information on compressional and shear wave velocities in the immediate vicinity of each borehole. Travel times of signals from an impulsive source of energy at the surface are measured to various depths in the borehole. The corresponding plot of travel time versus depth is then converted to velocity versus depth by computing slopes of the interpreted major straight-line segments of the plotted data (BSC 2002 [DIRS 157829], Section 6.2.5).

These borehole-based data are complemented by SASW surveys, which provide information on shear-wave velocity as a function of depth over the length of the survey line. The SASW methodology is a non-destructive and non-intrusive seismic method. It utilizes the dispersive nature of Rayleigh-type surface waves propagating through a layered material to estimate the shear-wave velocity profile of the material (Stokoe et al. 1994 [DIRS 157265]). In this context, dispersion arises when surface-wave velocity varies with wavelength or frequency. Dispersion in surface-wave velocity arises from changing stiffness properties of the soil and rock layers with depth. Spectral analysis is used to separate the waves by frequency and wavelength to determine the experimental ("field") dispersion curve for the site. An analytical procedure is then used to theoretically match the field dispersion curve with a one-dimensional layered system of varying layer stiffness and thickness (Joh 1996 [DIRS 157248]). The one-dimensional shear-wave velocity profile that generates a dispersion curve that matches the field dispersion curve is presented as the profile at the site. Alternatively, the dispersion data can be formally inverted to obtain a velocity profile. For the current work scope, data inversion is planned to corroborate the forward-modeling results and to provide information on the ability of the data to resolve velocities as a function of depth.

Velocity data will be considered unexpected if, when combined with other available velocity data, they indicate that base case velocity profiles used in previous site-response modeling no longer adequately represent the velocity characteristics of the site. That is, if interpretations incorporating the newly acquired data differ from past interpretations, the responsible manager will be notified. Velocity profiles used in previous site-response modeling have DTNs: MO0206SASWVSP1.001 [DIRS 163777] and MO0209VELPRWHB.000 [DIRS 163798] and are discussed in MDL-MGR-GS-000003 REV 01 (BSC 2004 [DIRS 170027], Section 6.2.3). MDL-MGR-GS-000003 REV 01 also includes figures showing the range of velocity data previously collected (BSC 2004 [DIRS 170027], Figures 6.2-95 through 6.2-104, 
6.2-106, 6.2-107, 6.2-109, 6.2-110, and 6.2-112 through 6.2-115). As data are collected and processed, integration meetings will be held periodically with velocity profile analysts and siteresponse modelers to review results. If unexpected results, unexpected test conditions, or offnormal events are encountered, they will be handled as described in Section 2.1. Velocity profiles based on all available data will be used for future ground-motion site-response modeling to support the license application or licensing defense.

\section{Dynamic Material Properties Data}

Laboratory determination of dynamic material properties employs combined resonant column and torsional shear (RCTS) testing (BSC 2002 [DIRS 157829], Section 6.2.10). The RCTS apparatus can be idealized as a fixed-free system. The bottom end of the specimen is fixed against rotation at the base pedestal, and the top end of the specimen is connected to the driving system. The driving system can rotate freely to excite the specimen in cyclic torsion.

The basic operational principle of the fixed-free resonant column test is to vibrate the cylindrical specimen in first-mode torsional motion. Harmonic torsional excitation is applied to the top of the specimen over a range in frequencies, and the variation of the acceleration amplitude of the specimen with frequency is obtained. Once first-mode resonance is established, measurement of the resonant frequency and amplitude of vibration are made. These measurements are then combined with equipment characteristics and specimen size to calculate shear-wave velocity and shear modulus based on elastic wave propagation. Material damping is determined either from the width of the frequency response curve or from the free-vibration decay curve.

The torsional shear test is another method of determining shear modulus and material damping using the same RCTS equipment but operating it in a different manner. A cyclic torsional force with a given frequency, generally below $10 \mathrm{~Hz}$, is applied at the top of the specimen. Instead of determining the resonant frequency, the stress-strain hysteresis loop is determined from measuring the torque-twist response of the specimen. Proximitors are used to measure the angle of twist while the voltage applied to the coil is calibrated to yield torque. Shear modulus is calculated from the slope of a line through the end points of the hysteresis loop, and material damping is obtained from the area of the hysteresis loop.

In addition, laboratory testing will include free-free testing. Two types of free-free resonant column tests will be used. The first type is a multimode, free-free, resonant column test. In this test, a cylindrical specimen is excited in the following three different modes of wave propagation: (1) first-mode torsional resonance, (2) first-mode longitudinal resonance, and (3) end-to-end direct propagation of a constrained compression wave. Each mode of wave propagation is measured separately, all testing is performed in the small-strain range (strains less than $0.001 \%$ ) and all testing is performed when the specimen is unconfined. In all three modes, a transient impact is applied to one end of the specimen to excite the selected mode and accelerometers attached to the opposite end of the specimen are used to monitor motions. First-mode torsional resonance and first-mode longitudinal resonance are established from frequency response curves. The torsional response curve is combined with the specimen characteristics to determine shear-wave velocity, shear modulus and material damping in shear. The longitudinal response curve is combined with the specimen characteristics to determine unconstrained-compression-wave velocity, Young's modulus and material damping in 
unconstrained compression. Measurement of the end-to-end travel time of the constrained-compression wave is combined with equipment and specimen characteristics to determine the constrained-compression-wave velocity and the constrained modulus.

The second type of free-free resonant test is a large-scale torsional resonant column test. Large specimens, typically 6 in. in diameter and approximately $12 \mathrm{in.}$ in height, are vibrated in first-mode torsional motion. Sinusoidal torsional excitation is applied at the base of the specimen over a range in frequencies, and the variation of the acceleration amplitude at the top of the specimen with frequency is obtained. Once first-mode resonance is established, measurements of the resonant frequency and amplitude of vibration are made. These measurements are then combined with equipment characteristics and specimen size to calculate shear-wave velocity and shear modulus based on elastic wave propagation. Material damping is determined from the width of the frequency response curve.

Laboratory measurements of tuff and alluvium dynamic properties have several objectives, which include:

- Measurement of shear modulus reduction and material damping as a function of increasing shear strain

- For alluvium, investigation of the effect of cementation on the dynamic properties

- Investigation of the effect of confining pressure.

Laboratory tests will involve samples from both existing and new boreholes, and larger (4-in to 6-in) tuff samples drilled from boulders found at the surface. Collection and testing of these larger samples are aimed at understanding the variation in results as a function of specimen size.

For alluvium samples, undisturbed samples will be obtained, if possible, from surface exposures and test pits. The term "undisturbed" refers to samples whose inherent grain-to-grain cementation has not been destroyed by the drilling or extraction process. Attempts will be made to hand-extract samples of 6-in to 12-in diameter and 12-in to 24-in long. The samples would be gradually exposed from the walls of the test pit in an incremental fashion using hand tools. The use of a silicate spray (or some similar method) on the surface of the sample as it is incrementally exposed controls raveling of the sample surfaces, and maintains sample moisture content at in situ conditions. Curves of shear modulus reduction and material damping with increasing shearing strain will be measured. Measurements will be performed in the linear and nonlinear ranges, with the highest nonlinear tests potentially reaching failure.

If attempts to obtain undisturbed samples are unsuccessful, the laboratory measurements will involve use of specimens reconstituted from cores retrieved from the sonic drilling program. Some alluvium specimens will have a cementing agent added so that the small-strain shear-wave velocity of the specimen matches that measured in the field. It is recognized that this cementation process may not duplicate the specific form of the cementation conditions in the field, but the measurements will provide additional information to guide scientific judgement used in developing inputs for the site-response model. Similar dynamic laboratory testing as 
described above for undisturbed samples will be made for the reconstituted samples if they are used.

In addition to laboratory testing of alluvium properties, in situ techniques for testing the dynamic properties of alluvium will also be implemented. In situ testing would avoid the disturbance inherent in collecting alluvium samples. However, in situ testing techniques would provide information on properties only of near-surface samples.

The field tests will measure the in situ variation in shear modulus as a function of strain at up to ten representative locations in the surface facilities area. These measurements will be performed in the alluvium and may extend to failure strains. The field arrangement involves dynamically loading circular concrete footings on the alluvial surface and measuring the resulting horizontal displacements and corresponding shear-wave velocities beneath the footings. Each footing will be cast in place. It will be loaded with a vertical static force and a range in horizontal dynamic forces. The horizontal forces will be sinusoidal. Stage loading will be performed, with the horizontal forces ranging from very small (creating $\gamma<10^{-4} \%$ in the alluvium) up to failure. A large mobile triaxial shaker will be used to apply the static and dynamic loads. The shaker can apply a maximum vertical static load of $60,000 \mathrm{lb}$ and a peak horizontal sinusoidal load of $30,000 \mathrm{lb}$. Dynamic motions in the alluvium beneath the footings will be measured with an embedded array of geophones. The geophones will be grouted in vertical boreholes beneath the central portion of the footing. Sets of biaxial geophones will be used in each borehole. The geophones will be arranged to form the corner points of quadrilaterals in a vertical plane beneath the footing. Each quadrilateral will be used to calculate shearing strains and shear-wave velocities. The end-product of these measurements is a shear modulus reduction curve, ranging from the linear portion to highly nonlinear values, likely reaching failure.

Dynamic material property data will be considered unexpected if, when combined with other available property data, they indicate that base case dynamic material property curves used in previous site-response modeling no longer adequately represent the material property characteristics of the site. That is, if interpretations incorporating the newly acquired data are inconsistent with past interpretations, the responsible manager will be notified. Dynamic material property curves used in previous site-response modeling have DTN: MO0403SDIAWHBC.003 [DIRS 170434] and are discussed in MDL-MGR-GS-000003 REV 01 (BSC 2004 [DIRS 170027], Section 6.2.4). MDL-MGR-GS-000003 REV 01 also includes figures showing the range of dynamic material property data previously collected and interpreted curves used as input to site-response modeling (BSC 2004 [DIRS 170027], Figures 6.2-131 through 6.2-133, $6.2-135,6.2-136,6.2-139,6.2-140$, and 6.2-147). As data are collected and processed, integration meetings will be held periodically with dynamic material property analysts and siteresponse modelers to review results. If unexpected results, unexpected test conditions, or offnormal events are encountered, they will be handled as described in Section 2.1. Dynamic material property curves based on all available data will be used for future ground-motion siteresponse modeling to support the license application or licensing defense.

\section{Fracture Studies Supporting Assessment of Extreme Ground Motion}

Field geologic studies of fractures in underground excavations will address the issue of the level of ground motion that has been experienced at Yucca Mountain. Previous analysis of existing 
fracture data led to the conclusion that pervasive, interlithophysal fractures, such as would be generated by extreme levels of ground motion, are not observed at Yucca Mountain (BSC 2005 [DIRS 170137], Appendix A). This conclusion leads to the establishment of a reasonable bound to the level of ground motion considered in the total system performance assessment. Geologic studies are planned to confirm and strengthen the current conclusion by explicitly looking for fractures showing the predicted characteristics that extreme ground motion would produce. Lithostratigraphic mapping and other forms of documentation of lithostratigraphic features will be done in tunnels and on core samples from Yucca Mountain. Four tasks will be conducted with the first three involving field work in the tunnels and the fourth involving core samples. One task is to check (and possibly re-measure) previously documented fracture data (mostly Detailed line survey data obtained by the BOR during the construction of the ESF and ECRB) to refine the measurements of separation across fractures, shears and faults. The second task is to document the shapes of lithophysae in terms of having "initial" shapes (those that formed shortly after deposition and welding) or exhibiting evidence of "damage" resulting from strain of the rocks (possibly induced by past seismic activity). The third task is to use the Panel Map and Panel Photograph locations from the lithophysal study to make detailed maps of fractures and their relations to lithophysae. The fourth task is to complete the digital maps of fractures in slabs of core. Results of these tasks will be used to assess whether observed fractures exhibit the characteristics predicted to develop if an extreme level of ground motion was ever experienced at Yucca Mountain.

An unexpected result for this test would be the identification of pervasive fracturing interconnecting lithophysae, consistent with the fracturing predicted by numerical modeling of large strain deformation. If unexpected results, unexpected test conditions, or off-normal events are encountered, they will be handled as described in Section 2.1 .

Field and laboratory testing activities do not directly address any features, events, or processes.

\subsubsection{Velocity Profile Development}

Velocity profile development activities are planned to update inputs to the ground-motion site-response model. For preclosure analyses supporting the license application, the updated velocity profiles will be used to develop updated ground motions for design and safety assessments. These updated profiles will be based on data available in October 2006. Velocity profiles will also be updated upon completion of planned geotechnical investigations in FYs 2007 and 2008. These profiles will be used to develop a final set of updated ground motions for both the preclosure and postclosure periods. Upon submittal of the final velocity profiles to the TDMS, superseding previous velocity profiles, an impact review will be initiated in accordance with AP-SIII.3Q. The final results will support defense of the license application.

The scientific approach and technical methods employed in updating velocity profiles used as input to the site-response model will be the same or similar to those documented in Development of Earthquake Ground Motion Input for Preclosure Seismic Design and Postclosure Performance Assessment of a Geologic Repository at Yucca Mountain, NV (BSC 2004 [DIRS 170027], Section 6.2.3). In that analysis, first the geometric mean of data collected with a certain technique (e.g., SASW, downhole, suspension logging) was obtained as a function of depth. Then the geometric mean of the means for the various techniques was computed as a 
function of depth. Statistics of the data were also determined. If results indicate that multiple mean profiles are needed to characterize the repository block or surface facilities area completely, multiple base-case profiles will be developed. If results indicate that data collected with different techniques have different levels of reliability, are more pertinent to the task of determining velocity profiles for site-response modeling, or provide redundant information, the data sets will be weighted in determining final profiles.

As part of the analysis of velocity data, the correlation between velocity, lithostratigraphy, and material physical properties will be examined. The analysis will include a quantitative assessment of correlation such as testing the mean velocities of different lithostratigraphic units to determine if they are statistically different. If a correlation is identified, the process to develop velocity profiles will be modified to incorporate the results, as appropriate.

Also supporting the analysis of the correlation between velocity and lithostratigraphy, a three-dimensional representation of velocity at the site will be developed using EarthVision software. This representation will be compared to the geologic framework model for Yucca Mountain (BSC 2004 [DIRS 170029]) to aid in understanding the relation between velocity layers and lithostratigraphic layers. The data will be analyzed at two scales-one for the repository block and one for the site of the surface facilities. Borehole-based velocity data and data from SASW surveys will form the basis of the representations. For the surface facilities area, a more detailed representation of the subsurface geology will also be developed. In developing these representations, standard geologic principles and practice will be employed.

In addition to developing velocity profiles for the repository block and surface facilities area, work will also be performed to update the analysis of correlation between profile layer velocity and layer thickness. This analysis is used to stochastically generate a suite of velocity profiles based on a given base case profile to incorporate aleatory variability in site velocity into the siteresponse modeling calculations. Details of the methodology are provided in Development of Earthquake Ground Motion Input for Preclosure Seismic Design and Postclosure Performance Assessment of a Geologic Repository at Yucca Mountain, NV (BSC 2004 [DIRS 170027], Section 6.2.3.6).

The activity to develop velocity profiles for ground-motion site-response modeling does not directly address any features, events, or processes.

\subsubsection{Dynamic Material Property Curve Development}

Activities to develop dynamic material property curves will update previous inputs to the ground-motion site-response model. For preclosure analyses supporting the license application, the updated material property curves will be used to develop updated ground motions for design and safety assessments. These updated property curves will be based on data available in October 2006. Dynamic material property curves will also be updated upon completion of planned geotechnical investigations in FY 2007. These property curves will be used to develop a final set of updated ground motions for both the preclosure and postclosure periods. Upon submittal of the final curves to the TDMS, superseding previous curves, an impact review will be initiated in accordance with AP-SIII.3Q.Results will support defense of the license application. 
Curves characterizing dynamic material properties of tuff and alluvium form one of the inputs to site-response modeling. The scientific approach and technical methods employed in updating dynamic material property curves will be the same or similar to those documented in Development of Earthquake Ground Motion Input for Preclosure Seismic Design and Postclosure Performance Assessment of a Geologic Repository at Yucca Mountain, NV (BSC 2004 [DIRS 170027], Section 6.2.4). Curves of shear modulus (normalized to its low-strain value) and hysteretic damping as a function of shear strain will be evaluated on the basis of existing and new laboratory testing results, inferences concerning the relation between laboratory results and in situ rock mass conditions, information in the scientific literature, and scientific judgment. As part of the effort to understand effects of test sample size and limitations on shear strains that can be reached in the laboratory, numerical simulations of tuff deformation will also be performed. These simulations will use the computer codes PFC2D (or PFC3D) and UDEC (or 3DEC). Simulations will involve numerical samples that are larger than can be tested in the laboratory, and will include fractures and lithophysae at a larger scale than can be included in test samples. Data for tuff will also be examined to determine if they warrant subdivision of the dynamic material properties on the basis of, for example, whether the tuff is welded or not.

Current ground motion results do not take into account effects of confining pressure on dynamic material property curves. As part of the effort to examine conservatism in the current results, the effect of confining pressure will be assessed and may be incorporated into future site-response modeling. For tuff, effects of confinement will be based on results of numerical modeling of rock mass behavior using the computer code PFC2D or PFC3D. For alluvium, effects of confining pressure will be based on generic curves (EPRI 1993 [DIRS 103322]), testing results, and scientific judgement.

In addition, nonlinear behavior for $\mathrm{P}$-wave propagation is not included in current ground motion site-response modeling. Future modeling efforts may incorporate nonlinear $\mathrm{P}$-wave propagation for comparison to results of the current linear approach. Curves of constrained modulus and damping, as a function of shear strain, will be developed from information in the scientific literature and scientific judgement.

Scientists will use their judgement to assess testing data, the limitations of the data, and other available information to decide if epistemic uncertainty in dynamic material properties requires use of multiple mean sets of curves for tuff or alluvium. In past site-response modeling, two sets of curves have been used and ground motion results have been enveloped. If multiple base-case sets of curves are needed for future site-response modeling, weights may be developed for the sets of curves to allow the computation of a weighted average of ground motion probabilities.

The activity to update dynamic material property curves for ground-motion site-response. modeling does not directly address any features, events, or processes.

\subsubsection{Enhancement of Technical Basis for Model Validation}

Validation of the RVT-based equivalent-linear site-response model is described in Development of Earthquake Ground Motion Input for Preclosure Seismic Design and Postclosure Performance Assessment of a Geologic Repository at Yucca Mountain, NV (BSC 2004 [DIRS 170027], Section 7). While the required level of confidence in the site-response model 
has been obtained, additional work is planned to expand and enhance the technical basis for the validation and increase confidence in the model beyond the required level for licensing defense.

One task to expand and enhance the technical basis for model validation involves demonstrating that results of the model are consistent with site-specific data. Several data sets exist at Yucca Mountain that allow the comparison of ground motion at depth to that at the surface. These data sets are recorded at UZ-16, at three of the Repository Surface Facility boreholes at the surface facilities area, and within the ESF and at the surface of Yucca Mountain above the ESF. Events recorded at these sites will be examined to calculate the observed response spectra transfer function in propagating from depth to the surface. The observed transfer functions will then be compared to results of the site-response model for the same depth range. While these comparisons involve weak ground motion rather than strong ground motion that might cause nonlinear behavior, they are intended to show that available site-specific data are consistent with the model used.

A second task to expand and enhance the technical basis for model validation involves comparison of the results of the RVT-based equivalent-linear site-response model to results of alternative nonlinear models for site-specific conditions. Development of Earthquake Ground Motion Input for Preclosure Seismic Design and Postclosure Performance Assessment of a Geologic Repository at Yucca Mountain, NV (BSC 2004 [DIRS 170027], Section 7) describes a comparison of the RVT-based equivalent-linear site-response model to nonlinear models for two sites in California, one in Taiwan, and one in Japan. For these sites, strong-motion data were available for a soil location and a nearby or at-depth rock location. The recorded rock motions were used as input to site response modeling of the soil location. In the planned task, the comparison of the alternative models will be extended to conditions and material properties at Yucca Mountain. For the surface facilities area, model inputs will consist of $1 \times 10^{-3}$ and $1 \times 10^{-4}$ annual frequency of exceedance ground motions and for the repository block $1 \times 10^{-3}$, $1 \times 10^{-5}$, and $1 \times 10^{-6}$ annual exceedance ground motions. The comparison will be performed using the most current set of velocity profiles and dynamic material property curves.

A third task to expand and enhance the technical basis for model validation involves demonstrating that site-response modeling results using Approach 2B of NUREG/CR-6728 (McGuire et al. 2001 [DIRS 157510], Section 6.1) for the waste emplacement level and for low annual frequencies of exceedance are consistent with those using Approach 4. Approach 2B was used to develop ground motion inputs reported in Development of Earthquake Ground Motion Input for Preclosure Seismic Design and Postclosure Performance Assessment of a Geologic Repository at Yucca Mountain, NV (BSC 2004 [DIRS 170027]). An attenuation curve for the waste emplacement level will be determined on the basis of ground motion modeling for a limited set of earthquakes that dominate the seismic hazard for the site. The attenuation curve will then be used in a simplified probabilistic seismic hazard analysis to calculate directly ground motions for the waste emplacement level and at low annual frequencies of exceedance. These results will be compared to those obtained using Approach 2B. In addition, an approximation to Approach 3 (McGuire et al. 2002 [DIRS 163799], Section 6.2) will be evaluated relative to Approaches 2B and 4. Approach 3 is planned for use to develop the mean seismic hazard curve for the surface facilities area and updated ground motions for preclosure design and safety analyses. 
A fourth task to expand and enhance the technical basis for model validation consists of two-dimensional modeling of topographic and tuff-alluvium interface effects on ground motion. Two- and three-dimensional ground motion effects are implicitly reflected in the strong ground motion data used to develop standard attenuation relationships used in the PSHA. In this task, such potential effects would be explicitly characterized for Yucca Mountain using two-dimensional finite-difference modeling. Demonstrating the magnitude of such effects would provide additional confidence that they are accommodated in the current approach. Two-dimensional modeling of S-wave propagation will use a uniform velocity profile and topography profiles derived from the geologic framework model (BSC 2004 [DIRS 170029]). A suite of east-west and north-south profiles will be used to examine the magnitude and sensitivity of any two-dimensional ground motion effect. In addition, possible two-dimensional ground motion effects related to the dipping interface between tuff and alluvium at the surface facilities area will be investigated using the same method. Also, two-dimensional modeling will be used to assess effects related to the different velocity profiles found on opposite sides of the Exile Hill splay fault or similar faults.

A fifth task is planned to expand and enhance the technical basis for the value of site attenuation (kappa) used for Yucca Mountain. Kappa is a parameter that describes local seismic wave attenuation. In carrying out the PSHA, a value of kappa determined from information available at the time was used (20 msec at the surface, $18.6 \mathrm{msec}$ at the PSHA reference rock outcrop). An analysis will be conducted to expand and enhance the technical basis for the value used in the PSHA. Site-specific data from stations in the vicinity of Yucca Mountain will be used to invert for kappa in a manner consistent with the site-response modeling.

If results of activities to enhance the technical basis for model validation do not confirm previous conclusions, the unexpected results will be addressed as described in Section 2.1.

The activity to enhance the technical basis for model validation does not directly address any features, events, or processes.

\subsubsection{Update Site Response Model}

As part of the effort to examine conservative aspects of the current site-response modeling approach, the site-response model for vertical ground motions will be updated to include nonlinear effects. Currently, vertical ground motion is modeled using linear wave propagation consistent with standard practice. However, for vertical ground motions at the surface facilities area with low annual probabilities of exceedance, nonlinear effects may become significant. The equivalent-linear method will be used to model nonlinear behavior for vertical motion, similar to the approach for horizontal motion. As discussed above, curves representing the variation in constrained modulus and damping as a function of shear strain will be developed to support the implementation of nonlinear P-wave propagation.

As part of the activity to update the site-response model an analysis will be performed to determine site-specific vertical-to-horizontal $(\mathrm{V} / \mathrm{H})$ ratios that can be used to adjust the vertical uniform hazard spectrum from the PSHA. For the existing ground motion inputs (BSC 2004 [DIRS 170027], Section 6.2), the V/H ratio used to adjust the vertical PSHA results was determined as recommended in NUREG/CR-6728 (McGuire et al. 2001 [DIRS 157510]). A 
weighted average of $\mathrm{V} / \mathrm{H}$ curves for the western U.S. and for the central and eastern U.S. was used. Weights for the curves were based on the value of kappa at Yucca Mountain in comparison to average values for the western U.S. and the central and eastern U.S.

To refine the $\mathrm{V} / \mathrm{H}$ ratios used to adjust vertical ground motions for Yucca Mountain, a RVT-based point-source ground motion model will be used to calculate a site-specific V/H ratio. Inputs to the model will be based on an analysis of the available scientific literature. Results of this work will be compared to the $\mathrm{V} / \mathrm{H}$ ratios determined following the recommendations in NUREG/CR-6728 (McGuire et al. 2001 [DIRS 157510]) and the impact on existing ground motion inputs will be evaluated. For any future site-response modeling, the updated $\mathrm{V} / \mathrm{H}$ ratios will be used.

Updates to the site response model will be documented in MDL-MGR-GS-000003 REV 03 (FY 2008).

The activity to update the ground-motion site-response model does not directly address any features, events, or processes.

\subsubsection{Update Preclosure Ground Motions}

Ground motions for preclosure design activities that support the license application will be updated based on geotechnical data available in October 2006. In contrast to previous ground motion development, which used NUREG/CR-6728 Approach 2B, future ground motions will be developed using Approach 3 (McGuire et al. 2001 [DIRS 157510], Section 6.1). Approach 2B is more deterministic in nature and involves scaling the uniform hazard spectrum for the PSHA reference rock outcrop. Ground motion differences resulting from epistemic uncertainty are enveloped. Approach 3 is more probabilistic in nature and involves calculating the soil hazard from the PSHA reference rock hazard by integrating over ground motion, and over magnitude and distance given a level of ground motion. Differences in the probabilities of ground motion resulting from epistemic uncertainty will be averaged. Weighting of alternate characterizations of site properties, in accordance with their support in the data, will be applied if appropriate. Results will be documented in an update (REV 02) of MDL-MGR-GS-000003 (FY 2007).

Approach 3 will be used for consistency with the approach used to develop seismic hazard curves for the surface facility area (see below), which are needed to respond to NRC concerns described in the letter by Kokajko (2006 [DIRS 176995]). Demonstration that the repository meets the preclosure performance objectives of 10 CRF 63 for seismic-initiated event sequences will use a probabilistic analysis.

A second round of ground motions will be developed, incorporating further updates of velocity and dynamic material property inputs, once geotechnical investigations are completed in FY 2007. Comparison of these ground motions to those used in analyses described in the license application will be performed. Submittal of this round of ground motions to the TDMS will cause an impact review to be initiated such that impacts of the new ground motions on license application analyses will be evaluated. It is anticipated that the updated preclosure ground motions will demonstrate that the ground motions used in design analyses are adequate. Results will be documented in a second update (REV 03) of MDL-MGR-GS-000003 (FY 2008). 
As part of the activity to update preclosure ground motions, sensitivity of calculated ground motions to the depth at which a shear-wave velocity of $1,900 \mathrm{~m} / \mathrm{sec}$ (Point A) is reached and the velocity at the repository level will be performed. Ground motions developed in MDL-MGRGS-000003 REV 01 were based on velocity profiles determined from data available in 2002. These velocity profiles reach a shear-wave velocity of $1,900 \mathrm{~m} / \mathrm{sec}$ (the reference rock outcrop condition for Point A from the PSHA) at the repository level. Additional data gathered since 2002 indicate that the Point A velocity is reached at a depth beneath the repository level at least in some areas. The sensitivity calculations will examine the effect on ground motion of assuming different values for the depth at which a shear-wave velocity of $1,900 \mathrm{~m} / \mathrm{sec}$ is reached and different values for the corresponding velocity at the repository level. Results will be described in an update (REV 02) of the report MDL-MGR-GS-000003 (FY 2007).

Site-specific ground motion inputs are developed using a one-dimensional equivalent-linear model (BSC 2004 [DIRS 170027], Section 6.1). This model addresses wave propagation through the rock/soil column and nonlinear behavior of the material under dynamic shear loading conditions. Results of the PSHA provide a control (input) motion; the power spectrum of the control motion is propagated through the rock/soil column using the P-SV or SH propagators of Silva (1976 [DIRS 103326]). Nonlinear properties of the rock/soil layers are treated using an equivalent linear approach (Seed and Idriss 1970 [DIRS 103324]). The approach approximates a second-order nonlinear equation over a limited range of its variables by a linear equation. Random vibration theory is used to determine peak time domain values of shear strain based on the shear-strain power spectrum. Strain-dependent shear modulus and hysteretic damping curves are then used to define new parameters for each layer based on the effective strain computations. This process is repeated until the changes in parameters are below a specified tolerance level.

The control motion inputs to the site-response model, taken from the PSHA results, will be conditioned by results of new data and analyses indicating that it is reasonable to bound ground motions at Yucca Mountain (e.g., BSC 2005 [DIRS 170137]). Input ground motions will be limited to those that do not cause shear strains large enough to fracture the rock because such damage is not observed in underground excavations at Yucca Mountain. In addition, data on the stress drops observed for recorded earthquakes will be investigated to assess a reasonable bound to stress drop. This assessment will take into account new data on the value of stress drops associated with earthquakes that result primarily from deep slip versus those that result primarily from shallow slip. . Ground motions associated with such a stress drop, taking into account variability in other parameters affecting ground motion, will be calculated using a RVT-based point-source ground motion model coupled with the Yucca Mountain site-response model. These approaches also support development of postclosure ground motions (see below).

The activity to update preclosure ground motion inputs does not directly address any features, events, or processes.

\subsubsection{Update YMP/TR-003-NP, Preclosure Seismic Design Methodology for a Geologic Repository at Yucca Mountain}

The DOE described their proposed approach to preclosure seismic design in YMP/TR-003-NP REV 03 (Preclosure Seismic Design Methodology for a Geologic Repository at Yucca Mountain), which was provided to the NRC for their review. The NRC responded (Kokajko 
2006 [DIRS 176995]) that the proposed approach provided useful information, but did not demonstrate that the performance objectives in 10 CFR 63 [DIRS 176544] would be met. Thus, additional analyses would be needed. To further clarify their position, NRC also issued Draft Interim Staff Guidance HLWRS-ISG-01 (71 FR 29369 [DIRS 177351]). In response to this feedback from the NRC, a methodology report will be prepared to update YMP/TR-003-NP. The methodology report will include a description of preclosure seismic design criteria and probabilistic analyses that will be performed to demonstrate preclosure compliance. The probabilistic analyses will draw upon experience from other. NRC-regulated facilities and industry standards. Consistent with the updated content, the title of the report will be changed to Preclosure Seismic Design and Performance Demonstration Methodology for a Geologic Repository at Yucca Mountain.

As indicated in Section 4, this document will be prepared using PA-PRO-0313 as a DOE report for submittal by DOE to the NRC.

\subsubsection{Update Postclosure Ground Motions}

Development of ground motion inputs for postclosure analyses is described in Development of Earthquake Ground Motion Input for Preclosure Seismic Design and Postclosure Performance Assessment of a Geologic Repository at Yucca Mountain, NV (BSC 2004 [DIRS 170027], Section 6.3). These ground motions are unbounded. Dynamic shear strains associated with some of these ground motions are likely larger than the tuff at Yucca Mountain can sustain without fracturing. To address this issue, a study was performed to constrain the level of extreme ground motion that has been experienced at Yucca Mountain (BSC 2005 [DIRS 170137]). This constraint is taken as a reasonable limit to ground motions considered in the TSPA and is used to develop a constrained hazard curve for the waste emplacement level.

Planned work to update postclosure ground motions supports licensing defense. One component of the planned work involves strengthening the technical basis for establishing a reasonable limit to ground motion at Yucca Mountain. Results will be documented in an update (REV 01) of ANL-MGR-GS-000004. The first task of this work is updating the numerical modeling of lithophysal tuff deformation. Modeling will be updated to reflect any new data on tuff and fracture properties and preexisting cooling fractures will be incorporated into the model. Results of this modeling and any other new information will be incorporated into an update of the probability distribution for the shear strain increment required to initiate macroscopic fracturing of lithophysal tuff. Finally, the site-response analyses used to determine the relation between ground motion level and dynamic shear strain at the depth of the lithophysal tuff at Yucca Mountain will be updated and expanded. Updated site-response modeling will be performed using updated velocity profile and dynamic material property data. The analysis will be expanded to address other ground motion measures (i.e., response spectral acceleration at a suite of oscillator frequencies) than horizontal peak ground velocity. Based on the site response modeling results, a response spectrum will be developed that is associated with the shear strain increment that would cause fracture of the lithophysal tuff. This response spectrum will represent a limit to ground motion experienced at Yucca Mountain.

Another task to strengthen the technical basis for limiting ground motion at Yucca Mountain consists of using RVT-based point-source and finite-source ground motion models to assess the 
probability of extreme ground motions at Yucca Mountain. For a scenario earthquake consistent with seismic hazard deaggregation at low annual frequencies of exceedance, the point-source and finite-source ground motion models will be used to generate a ground motion probability distribution. Inputs to the models (e.g., stress parameter, earthquake source depth, regional attenuation, site attenuation) will be stochastically sampled from distributions established through literature studies. For the finite-source model, slip distribution on the fault will be determined stochastically, but constrained such that its characteristics are consistent with observed earthquake slip distributions. New data indicating that earthquake stress drop varies depending on whether the earthquake is dominated by shallow or deep slip will be summarized and incorporated into the analysis. Also in support of this task, an inversion technique will be used to determine the stress drops of some recent normal-faulting earthquakes.

To better define the conservatism in the unbounded ground motions used to perform kinematic and structural response calculations and to provide more realistic ground motions for any future analyses, a new approach will be developed for generating time histories for postclosure analyses that incorporates a limit to ground motion. Elements that will be evaluated for incorporation in the new approach include:

- Use of a ground motion measure other than peak ground velocity to scale time histories.

- Selection of basis time histories using information not only on their magnitude and distance, but also their deviation from standard ground motion attenuation relationships (i.e., epsilon).

- Constraint of the time history response spectra such that they do not exceed ground motions that have never been experienced at Yucca Mountain.

To support the development of this new approach, a number of tasks will be performed.

First, results of existing seismic response calculations will be examined to determine if a ground motion measure other than peak ground velocity shows a better correlation with damage to EBS components. As part of this task, the catalog of strong ground motion records used to develop time histories will be analyzed to determine the observed correlation between different ground motion measures.

Second, the catalog of strong motion records will also be analyzed to characterize each record in terms of its deviation from standard ground motion attenuation relationships (epsilon). Site-specific time histories for Yucca Mountain are based on accelerograms recorded worldwide. In developing the current set of time histories for postclosure analyses, strong ground motion records were selected to have a similar magnitude and distance to the earthquakes dominating the seismic hazard at a given annual frequency of exceedance. In future development of time histories, the epsilon associated with the records may also be considered in selecting basis strong motion records. Records in the strong ground motion database will be binned according to epsilon in addition to the current binning according to magnitude, distance, and site type (i.e., rock or soil). 
Once the supporting tasks have been completed and a new approach for developing time histories determined, new suites of time histories will be calculated. These new time histories will be used to confirm the conservatism of existing postclosure time histories (BSC 2004 [DIRS 170027], Section 6.3) and for use in future analyses examining the conservatism of postclosure analyses of seismic structural response and rockfall. The new suites of time histories will consist of 15 to 20 sets of three-component synthetic seismograms. They will be developed for ground motion with annual frequencies of exceedance of $1 \times 10^{-5}, 1 \times 10^{-6}$, and for an upper bound to ground motions considered in the TSPA, as appropriate. Submittal of this round of ground motions to the TDMS will cause an impact review to be initiated such that impacts of the new ground motions on license application analyses will be performed. It is anticipated that the updated postclosure ground motions will demonstrate that the ground motions used in design analyses are conservative. Results will be documented in an update (REV 03) of MDL-MGRGS-000003 (FY 2008).

Conservatism of unbounded low-frequency-of-exceedance ground motions will also be examined through a task to update the hazard curves for the waste emplacement level using Bayesian techniques. Information that has become available since the PSHA was performed (e.g., evidence that extreme ground motions have not occurred at Yucca Mountain in 12.8 million years) will form the basis for the update.

No model modification will be required to extend ground motion model results for use in assessments of postclosure performance beyond 10,000 years after repository closure. The same updated and bounded ground motions developed for future use in analyses of seismic consequences for the first 10,000 years will also be used for 10,000 years after closure.

The activity to update postclosure ground motion inputs does not directly address any features, events, or processes.

\subsubsection{Evaluate Impact of New Data on the PSHA Results}

To evaluate the impact of new data on the PSHA results, first new data will be compiled from the scientific literature. New data may consist of information on seismic sources in the Yucca Mountain vicinity, including their locations, rates of activity, and maximum magnitudes. New data may also include new ground motion attenuation relationships for the western United States and new information on the amount and distribution of surface fault displacement associated with earthquakes. The second part of the evaluation will consist of analyses to determine the impact, if any, of the new information on the PSHA results. The new data will be analyzed to determine whether they are consistent with the interpretations made by the PSHA experts when the PSHA was originally performed. Sensitivity analyses, such as PSHA calculations using new sources, new seismicity rates, or new ground motion attenuation relations, may also be used to determine how potential changes to the experts' interpretations based on new information would affect the calculated level of seismic hazard. Results will be documented in a new analysis report.

The activity to evaluate the impact of new data on the PSHA results does not directly address any features, events, or processes. 


\subsubsection{Develop a Seismic Hazard Curve for the Surface Facilities Area}

A seismic hazard curve for the surface facilities area will be determined using the RVT-based equivalent-linear site-response model. Approach 3 of NUREG/CR-6728 (McGuire et al. 2001 [DIRS 157510], Section 6.1) will be used to allow a mean curve to be developed. Hazard results for different combinations of base-case inputs covering the range of epistemic uncertainty will be averaged. In addition, inferences concerning the limit of extreme ground motion that Yucca Mountain has experienced will be incorporated into the analysis. Two approaches to limiting extreme ground motion will be considered. One will take the results described in ANL-MGRGS-000004 REV 00 for the waste emplacement level and apply them to the rock underlying the surface facility area. This approach implements a reasonable bound to extreme ground motion at Yucca Mountain by observing that characteristic fracture patterns, which would be expected if extreme ground motion had occurred in the past 12.8 million years, are not seen in underground excavations. A second approach will be to examine new information on earthquake stress drops and its implications for extreme ground motion. Incorporation of the results of these approaches will provide a hazard curve that is reasonable at low annual probabilities of exceedance and consistent with the geologic setting of the site. Results based on geotechnical data available in October 2006 will be documented in an update (REV 02) of MDL-MGR-GS-000003 (FY 2007). Results of a second round of analyses based on data available when all planned geotechnical investigations are completed will be documented in a further update (REV 03) of MDL-MGRGS-000003 (FY 2008).

The activity to evaluate the impact of new data on the PSHA results does not directly address any features, events, or processes.

For all the tasks discussed above, results will be recorded in scientific notebooks and analysis, model, or technical reports in accordance with applicable YMP procedures.

\subsection{MODEL USE AND MODEL VALIDATION}

As part of the planned work, existing models will be used. Some of these models have been previously validated and they will be used as intended and within their range of validity. For these models, this section provides justification for their use. Two models have not yet been validated. For those models, this section describes the required level of confidence and the approach for validating the models.

\subsubsection{Geologic Framework Model}

The geologic framework model (BSC 2004 [DIRS 170029]) will be used as the basis for geologic information used to evaluate the correlation between seismic velocity data and lithostratigraphy. The model will also serve as the source of topographic data used in analyses to examine two-dimensional ground motion effects for the repository block. Use of this model is appropriate because it represents the integrated model of site geology. The model has been previously validated (BSC 2004 [DIRS 170029], Section 7) and will be used within its range of validity. No additional validation activities are planned. 


\subsubsection{PFC Discontinuum Model (PCF2D, PCF3D)}

The micromechanical discontinuum model implemented using the particle flow code (PFC) will be used to assess tuff dynamic material properties. Use of this model is justified because it provides a calibrated and validated representation of the deformation of lithophysal tuff at Yucca Mountain (BSC 2004 [DIRS 166107], Section 6, Section 7.5). The PFC approach represents rock as a number of small, rigid, spherical grains that are bonded together at their contacts with a shear and tensile strength, as well as a grain-to-grain friction angle after the "contact bond" has been broken. If cementing exists between grains, it can be represented with a "parallel bond" that provides a rotational resistance as well. The deformability of the contacts between particles is represented by a normal and shear stiffness at the contact point. Porosity is developed naturally in the model by control of the shape and size of void space between chains of bonded grains. The contact properties and porosity distribution are referred to as "microstructural" properties. Thus, the input conditions necessary for the model are very simple, only contact strength and stiffness. However, extremely rich constitutive behavior may develop naturally based on porosity and the few straightforward input properties, and their variability throughout the rock.

When load is applied to the grain assembly, forces are transmitted across contacts. If the shear or tensile strength of the contact is reached, failure will occur, and the adjacent particles are free to slide past one another, or to separate. In either case, a fracture is formed and the forces must reorient in some fashion, thus redistributing loads. Realistic failure mechanisms may then develop which can be compared to those observed in the laboratory. Calibration of the model against laboratory testing is necessary via sensitivity studies in which the contact strength and stiffness values are varied and the macroscopic stress-strain response is compared to that monitored.

The PFC discontinuum model has been previously validated (BSC 2004 [DIRS 166107], Section 7.5). The model will be used within its range of validity. Thus, no additional validation activities are planned.

\subsubsection{UDEC Discontinuum Model (UDEC, 3DEC)}

The discontinuum model implemented using the Universal Discrete Element Code (UDEC) software (or a three-dimensional version, 3DEC) will be used to evaluate tuff dynamic material properties and mechanical behavior. Use of this model is justified because it provides a calibrated and validated representation of the deformation of nonlithophysal tuff at Yucca Mountain (BSC 2004 [DIRS 166107], 'Section 6, Section 7.6). In the UDEC model, the rock mass is represented as an assembly of polygonal elastic blocks. Properties are selected such that the rock mass has proper deformability and strength characteristics, and responds elastically for stresses up to its peak strength. However, after the peak strength is reached, the model represents the failure process, including fracturing and dislodging of blocks under quasi-static and dynamic loading. This is accomplished by subdivision of the rock mass into many blocks of approximately the same size as those that may ultimately be formed during yielding. Fractures are bonded by the strength and stiffness values that allow correct representation of the rock mass strength and modulus. Prior to yielding, the fractures in the rock mass are essentially "invisible" or "incipient" and the rock mass behaves in an elastic, isotropic fashion during loading and 
unloading. However, once the shear or tension strength of the incipient fractures is reached, the rock mass can realistically fail through propagation of fractures and form unstable rock blocks that are free to dislodge and fall into the excavation as the forces dictate.

The UDEC/3DEC discontinuum model has been previously validated (BSC 2004 [DIRS 166107], Section 7.6). The model will be used within its range of validity. Thus, no additional validation activities are planned.

\subsubsection{RVT-based Equivalent-linear Site-response Model (RASCALS SET)}

Development of ground motion inputs based on updated information will use the RVT-based equivalent-linear site-response model. This model determines the effects of the rock/soil above the PSHA reference rock outcrop on the ground motions determined in the PSHA. The model determines how the site materials affect the response spectrum of earthquakes representing the Uniform Hazard Spectrum from the PSHA. The model addresses wave propagation through the rock/soil column and nonlinear behavior of the material under dynamic shear loading conditions. A one-dimensional model that employs a frequency domain approach is used (Silva and Lee 1987 [DIRS 103325]). Results of the PSHA provide a control motion; the power spectrum of the control motion is propagated through the rock/soil column using the P-SV or SH propagators of Silva (1976 [DIRS 103326]). Nonlinear properties of the rock/soil layers (i.e., strain-dependent shear modulus and damping) are treated using an equivalent linear approach (Seed and Idriss 1970 [DIRS 103324]). The approach approximates a second-order nonlinear equation over a limited range of its variables by a linear equation. Random vibration theory is used to determine peak time domain values of shear strain based on the shear-strain power spectrum. Strain-dependent shear modulus and hysteretic damping curves are then used to define new parameters for each layer based on the effective strain computations. This process is repeated until the changes in parameters are below a specified tolerance level. Use of this model is justified because it provides the effect on ground motions caused by propagation of the motion through the site materials.

The model will be used for SH-wave propagation (implemented using the software code RASCALS) as intended and within its range of validity. Level III validation of the model is documented in Development of Earthquake Ground Motion Input for Preclosure Design and Postclosure Performance Assessment of a Geologic Repository at Yucca Mountain (MDL-MGR-GS-000003. REV 00 and REV 01) (BSC 2003 [DIRS 166274], BSC 2004 [DIRS 170027]). Additional activities to expand and enhance the technical basis for model validation are described in Revision 01 of that model report (BSC 2004 [DIRS 170027], Section 7.3.5) ${ }^{2}$.

For P-SV-wave propagation (implemented using the software code RASCAL SET), the model may be used outside of its current range of validation. Current model validation treats vertical (P-SV) wave propagation in a linear fashion. To evaluate the conservatism of such treatment, vertical component site-response incorporating nonlinear P-wave propagation will be

\footnotetext{
${ }^{2}$ See Appendix A of this TWP for further discussion of validation of the RVT-based equivalent-linear site-response model and previous activities to enhance the technical basis for model validation beyond the level of confidence that is procedurally required.
} 
investigated. Activities to extend model validation to nonlinear P-wave propagation are planned. Validation will consist of comparing model results to data not used to develop or calibrate the model (LP-SIII.10Q-BSC, Section 5.3.2(a)(1)) and a technical review by reviewers independent of the development, checking, and review of the model documentation (LP-SIII:10Q-BSC, Section 5.3.2(a)(5)). It is anticipated that vertical seismic array data recorded in Japan and California will be used to corroborate the model. For model comparison to data, the validation criterion is that the model predictions adequately match the observed data, compared to ground motion modeling results in the scientific literature (e.g., Silva et al. (1996 [DIRS 110474], Section 5)), as judged by the modeler. Additional confidence will be provided by concurrence of the checker of the model report in which the validation is documented and by the review of the independent technical reviewer. For the technical review, the validation criterion is that technical review comments, if any, are acceptably resolved or a reason is provided for why the comment is not accepted. Review comments will be documented on comment sheets or in some other written format. Responses to comments and their acceptance will also be documented. Concurrence by the independent technical reviewer on the revised model documentation will also be obtained. The additional model validation will be documented in an update (REV 03) to MDL-MGR-GS-000003 (FY 2008). Definition of subject matter expertise, qualifications for reviewer(s), criteria for selecting reviewers, and specific responsibilities for each reviewer are addressed in Appendix B.

For this supplementary model validation activity, the responsible manager will meet with the report originator, checker, and independent technical reviewer to review model validation quality issues. The meeting with the originator will take place when the validation work begins. The meeting with the checker will take place prior to the start of the checking process. The meeting with the independent technical reviewer will take place prior to the start of the independent technical review that is performed as part of the PA-PRO-0601 review process. Meetings will be documented by an email from the Responsible Manager to his/her supervisor or other appropriate means.

\subsubsection{RVT-based Point-Source Ground Motion Model (RASCAL SET)}

A random vibration theory-based point-source ground motion model, implemented in the software code RASCAL SET, will be used to evaluate vertical-to-horizontal ground motion ratios for Yucca Mountain and to corroborate a bound to ground motion at Yucca Mountain in the context of ground motion expected from a scenario earthquake in the vicinity of the site. Because it is based on random vibration theory, this model is also referred to as a stochastic ground motion model. The model has been extensively validated outside of the Yucca Mountain Project (YMP) (Silva et al. 1996 [DIRS 110474]) using data from 16 earthquakes recorded at a combined total of over 500 stations and work is planned to document the validation in accordance with LP-SIII.10Q-BSC. The validation will be documented in an update (REV 02) of MDL-MGR-GS-000003 (FY 2007).

The guidelines for minimum levels of model validation (LP-2.29Q-BSC, Planning for Science Activities, Attachment 3) do not address seismic ground motion models. Because the model is being used to determine site-specific $\mathrm{V} / \mathrm{H}$ ratios, its validation is assessed as needing a high confidence (Level III). Validation will consist of comparing model results to data not used to develop or calibrate the model (LP-SIII.10Q-BSC, Section 5.3.2(a)(1)) and a technical review by 
reviewers independent of the development, checking, and review of the model documentation (LP-SIII.10Q-BSC, Section 5.3.2(a)(5)). The criterion for validation is that the model produces ground motion response spectra that are in reasonable agreement with observed data as judged by the modeler. Reasonable agreement will be based on calculations of modeling variability and model bias. Model variability is defined as the standard error of the residuals of the logarithm of the response spectra (5\% damped). The residual is defined as the difference of the logarithms of the observed and predicted response spectra. At each structural frequency of the response spectra, the residuals are squared and summed over the total number of sites for which data are being modeled for one or more earthquakes. Dividing the sum by the number of sites provides an estimate of the model variance. Model bias (average offset) is also determined and will form part of the model validation assessment. Additional confidence will be provided by concurrence of the checker and reviewers of the model report in which the model and its validation will be documented.

Demonstration that the model meets the criterion and has a high level of confidence will rely on previous work documented in Description and Validation of the Stochastic Ground Motion Model (Silva et al. 1996 [DIRS 110474], Section 5). Silva et al. (1996 [DIRS 110474], Section 5) address validation of both point-source and finite-source versions of the model. In the validation work, 16 earthquakes recorded at 502 sites, ranging in distance from about 1 to 125 miles for western United States conditions and about 3 to 280 miles for eastern United States conditions, were modeled. The results are evaluated in terms of model bias and variability. Model predictions are also compared to empirical attenuation relations and to western United States empirical statistical spectral shapes (Silva et al. 1996 [DIRS 110474], Sections 6 and 7).

For the technical review, the validation criterion is that technical review comments, if any, are acceptably resolved or a reason is provided for why the comment is not accepted. Review comments will be documented on comment sheets or in some other written format. Responses to comments and their acceptance will also be documented. Concurrence by the independent technical reviewer on the revised model documentation will also be obtained. Definition of subject matter expertise, qualifications for reviewer(s), criteria for selecting reviewers, and specific responsibilities for each reviewer are addressed in Appendix B.

As part of the work to document model validation, the responsible manager will meet with the model report originator, checker, and independent technical reviewer to review model validation quality issues. Because validation of the stochastic point-source model deals with documentation of previous work not performed under the auspices of the YMP, the meeting with the originator will take place when report preparation begins or before. The meeting with the checker will take place prior to the start of the checking process. The meeting with the independent technical reviewer will take place prior to the start of the start of the independent technical review that is performed as part of the PA-PRO-0601 review process. Meetings will be documented by an email from the responsible manager to his/her supervisor or other appropriate means.

\subsubsection{RVT-based Finite-Source Ground Motion Model (RASCALFS)}

A random vibration theory-based finite-source ground motion model, implemented in the software code RASCALFS, will be used to corroborate a bound to ground motion at Yucca 
Mountain in the context of ground motion expected from a scenario earthquake in the vicinity of the site. This model is similar to the stochastic point-source ground motion model, except that a collection of point-sources is used to represent the rupture of a fault with finite dimensions. The model has been extensively validated outside of the YMP (Silva et al. 1996 [DIRS 110474]) and work is planned to document the validation in accordance with LP-SIII.10Q-BSC. The validation will be documented in an update (REV 03) of MDL-MGR-GS-000003 (FY 2008).

The guidelines for minimum levels of model validation (LP-2.29Q-BSC, Planning for Science Activities, Attachment 3 ) do not address seismic ground motion models. Because the model will be used to assess bounds on ground motion at Yucca Mountain, its validation is assessed as needing a high confidence (Level III). Validation will consist of comparing model results to data not used to develop or calibrate the model (LP-SIII.10Q-BSC, Section 5.3.2(a)(1)) and a technical review by reviewers independent of the development, checking, and review of the model documentation (LP-SIII.10Q-BSC, Section 5.3.2(a)(5)). The criterion for validation is that the model produces ground motion response spectra that are in reasonable agreement with observed data as judged by the modeler. Reasonable agreement will be based on calculations of modeling variability and model bias. Model variability is defined as the standard error of the residuals of the logarithm of the response spectra ( $5 \%$ damped). The residual is defined as the difference of the logarithms of the observed and predicted response spectra. At each structural frequency of the response spectra, the residuals are squared and summed over the total number of sites for which data are being modeled for one or more earthquakes. Dividing the sum by the number of sites provides an estimate of the model variance. Model bias (average offset) is also determined and will form part of the model validation assessment. Additional confidence will be provided by concurrence of the checker and reviewers of the model report in which the model and its validation will be documented. Demonstration that the model meets the criterion and has a high level of confidence will rely on previous work documented by Silva et al. (1996 [DIRS 110474], Section 5).

For the technical review, the validation criterion is that technical review comments, if any, are acceptably resolved or a reason is provided for why the comment is not accepted. Review comments will be documented on comment sheets or in some other written format. Responses to comments and their acceptance will also be documented. Concurrence by the independent technical reviewer on the revised model documentation will also be obtained. Definition of subject matter expertise, qualifications for reviewer(s), criteria for selecting reviewers, and specific responsibilities for each reviewer are addressed in Appendix B.

As part of the work to document model validation, the responsible manager will meet with the model report originator, checker, and independent technical reviewer to review model validation quality issues. Because validation of the stochastic finite-source model deals with documentation of previous work not performed under the auspices of the YMP, the meeting with the originator will take place when report preparation begins or before. The meeting with the checker will take place prior to the start of the checking process. The meeting with the independent technical reviewer will take place prior to the start of the start of the independent technical review that is performed as part of the PA-PRO-0601 review process. Meetings will be documented by an email from the Responsible Manager to his/her supervisor or other appropriate means. 


\section{INDUSTRY STANDARDS, FEDERAL REGULATIONS, DOE ORDERS, REQUIREMENTS, AND ACCEPTANCE/COMPLETION CRITERIA}

This section identifies applicable standards and criteria. It also states provisions for determining the level of accuracy, precision, and representativeness of results. In addition, any requirements identified in source documents are listed.

\subsection{APPLICABLE STANDARDS}

ASTM standards apply to laboratory geotechnical testing and are listed in PA-PRO-0309 and PA-PRO-0310, Laboratory Dynamic Rock/Soil Testing.

There are no industrial or technical standards that are applicable to the development of seismic inputs.

\subsection{REGULATORY REQUIREMENTS}

Products developed under this TWP are expected to address, in whole or in part, requirements of 10 CFR 63 [DIRS 176544]. These requirements include 10 CFR 63 sections:

63.21(c)(1) A description of the Yucca Mountain site, with appropriate attention to those features, events, and processes of the site that might affect design of the geologic repository operations area and performance of the geologic repository. The description of the site must include information regarding features, events, and processes outside of the site to the extent the information is relevant and material to safety or performance of the geologic repository.

63.21(c)(9) An assessment to determine the degree to which those features, events, and processes of the site that are expected to materially affect compliance with $\S 63.113$ - whether beneficial or potentially adverse to performance of the geologic repository-have been characterized, and the extent to which they affect waste isolation.

63.101(a)(2) A reasonable expectation, on the basis of the record before the Commission, that the postclosure performance objectives will be met, is the general standard required. Compliance demonstrations should not exclude important parameters from assessments and analyses simply because they are difficult to precisely quantify to a high degree of confidence. The performance assessments and analyses should focus upon the full range of defensible and reasonable parameter distributions rather than only upon extreme physical situations and parameter values.

63.102(f) Preclosure safety analysis. Section 63.111 includes performance objectives for the geologic repository operations area for the period before permanent closure and decontamination or permanent closure, decontamination, and dismantlement of surface facilities. The preclosure safety analysis is a systematic examination of the site; the design; and the potential hazards, initiating events and their resulting event sequences and potential radiological exposures to 
workers and the public. Initiating events are to be considered for inclusion in the preclosure safety analysis for determining event sequences only if they are reasonable (i.e., based on the characteristics of the geologic setting and the human environment, and consistent with precedents adopted for nuclear facilities with comparable or higher risks to workers and the public). The analysis identifies structures, systems, and components important to safety.

63.102(j) Performance Assessment. Those features, events, and processes expected to materially affect compliance with $\S 63.113(\mathrm{~b})$ or be potentially adverse to performance are included, while events (event classes or scenario classes) that are very unlikely (less than one chance in 10,000 over 10,000 years) can be excluded from the analysis. An event class consists of all possible specific initiating events that are caused by a common natural process (e.g., the event class for seismicity includes the range of credible earthquakes for the Yucca Mountain site).

63.111(b) Numerical guides for design objectives. (1) The geologic repository operations area must be designed so that, taking into consideration Category 1 event sequences and until permanent closure has been completed, the aggregate radiation exposures and the aggregate radiation levels in both restricted and unrestricted areas, and the aggregate releases of radioactive materials to unrestricted areas, will be maintained within the limits specified in paragraph (a) of this section. (2) The geologic repository operations area must be designed so that, taking into consideration any single Category 2 event sequence and until permanent closure has been completed, no individual located on, or beyond, any point on the boundary of the site will receive, as a result of the single Category 2 event sequence, the more limiting of a TEDE of $0.05 \mathrm{~Sv}$ (5 rem), or the sum of the deep dose equivalent and the committed dose equivalent to any individual organ or tissue (other than the lens of the eye) of $0.5 \mathrm{~Sv}(50 \mathrm{rem})$. The lens dose equivalent may not exceed $0.15 \mathrm{~Sv}(15 \mathrm{rem})$, and the shallow dose equivalent to skin may not exceed $0.5 \mathrm{~Sv}(50 \mathrm{rem})$.

63.112(b)-(d) The preclosure safety analysis of the geologic repository operations area must include... (b) An identification and systematic analysis of naturally occurring and human-induced hazards at the geologic repository operations area, including a comprehensive identification of potential event sequences; (c) Data pertaining to the Yucca Mountain site, and the surrounding region to the extent necessary, used to identify naturally occurring and human induced hazards at the geologic repository operations area; (d) The technical basis for either inclusion or exclusion of specific, naturally occurring and human-induced hazards in the safety analysis.

63.114(a) Any performance assessment to demonstrate compliance with Section 63.113 must...include data related to the geology, hydrology, and geochemistry (including disruptive processes and events) of the Yucca Mountain site, and the surrounding region to the extent necessary, and information on the 
design of the engineered barrier system used to define parameters and conceptual models used in the assessment.

63.114(b) Any performance assessment to demonstrate compliance with Section 63.113 must...account for uncertainties and variabilities in parameter values and provide for the technical basis for parameter ranges, probability distributions, or bounding values used in the performance assessment.

63.114(c) Any performance assessment to demonstrate compliance with Section 63.113 must...consider alternative conceptual models of features and processes that are consistent with available data and current scientific understanding and evaluate the effects that alternative conceptual models have on the performance of the geologic repository.

63.114(d) Any performance assessment to demonstrate compliance with Section 63.113 must...consider only events that have at least one chance in 10,000 of occurring over 10,000 years.

63.114(e) Any performance assessment to demonstrate compliance with Section 63.113 must...provide the technical basis for either inclusion or exclusion of specific features, events, and processes in the performance assessment. Specific features, events, and processes must be evaluated in detail if the magnitude and time of the resulting radiological exposures to the reasonably maximally exposed individual, or radionuclide releases to the accessible environment, would be significantly changed by their omission.

63.114(f) Any performance assessment to demonstrate compliance with Section 63.113 must...provide the technical basis for either inclusion or exclusion of degradation, deterioration, or alteration processes of engineered barriers in the performance assessment, including those processes that would adversely affect the performance of natural barriers. Degradation, deterioration, or alteration processes of engineered barriers must be evaluated in detail if the magnitude and time of the resulting radiological exposures to the reasonably maximally exposed individual, or radionuclide releases to the accessible environment, would be significantly changed by their omission.

63.114(g) Any performance assessment to demonstrate compliance with Section 63.113 must...provide the technical basis for models used in the performance assessment such as comparisons made with outputs of detailed process-level models and/or empirical observations (e.g., laboratory testing, field investigations, and natural analogs).

The work described in this plan is not intended to respond to any key technical issue agreements between the DOE and the NRC. Seismic-related key technical issue agreements have been previously addressed or work to address them is planned in other TWPs. 


\subsection{LEVEL OF ACCURACY, PRECISION, AND REPRESENTATIVENESS OF RESULTS}

There are no predefined levels of accuracy, precision, and representativeness that the results must meet for any of the activities described in this TWP. It is expected that seismic inputs will meet levels of accuracy, precision, and representativeness that are consistent with the general state-of-the-practice on critical facility projects. Scientists carrying out the activities to develop seismic inputs will describe the representativeness of the results, as appropriate.

The accuracy and precision of geologic information obtained from boreholes is affected by the drilling method. The sonic coring method that will be used for drilling in the alluvium and through some bedded tuff units provides near continuous core. The sonic coring process disturbs materials, but changes in character and stratigraphic boundaries are well preserved. For boreholes that will be deepened using conventional drilling and coring methods, the accuracy and precision of determining geologic contacts depends on whether rock chips or core are obtained and on whether geophysical (density, resistivity) and video logs are available. Representativeness of geologic results is addressed by excavating boreholes at spatially distributed sites across area of interest.

The accuracy and precision of field testing to measure seismic velocities will be assessed by comparing results obtained using different measurement techniques. Also, for SASW measurements, formal inversions will be performed to quantitatively assess the resolution of velocities as a function of depth. Representativeness of velocity results is addressed by collecting velocity data from boreholes and along survey lines that are spatially distributed across the areas of interest.

For laboratory testing, the goal is to determine the dynamic material properties appropriate for in situ conditions. The accuracy and precision of laboratory-measured values relative to this goal will be assessed by evaluating samples of different size and by comparing shear-wave velocity measured in the laboratory to that measured in the field. Results from the scientific literature and scientific judgment will be used in determining in situ dynamic property curves based on the laboratory results, taking into account known limitations of laboratory data (e.g., BSC 2004 [DIRS 170027], Section 6.2.4). Uncertainties in how laboratory-measured properties correspond to in situ properties will also be incorporated into the development of inputs to the ground-motion site-response model. Representativeness of measured properties will be addressed by determining properties for samples from a range of lithostratigraphic units.

Model accuracy is determined as part of validation work. Model results are compared to data for situations in which the model inputs are reasonably well known and the misfit provides a measure of the model accuracy. Both model bias (average offset) and model variance are assessed. In addition to model variability, total prediction variability also includes parametric variability (i.e., variation in ground motion due to uncertainty and randomness in model input parameters).

The representativeness of the results must reflect the site conditions, including variability and uncertainty in those conditions. For the site-response ground motion model, representativeness is obtained by using base-case values of seismic velocity and material dynamic properties that 
are based on site-specific data and other information. Uncertainties are explicitly incorporated in the analysis to provide results that are representative of our current knowledge of the site.

For ground motions and fault displacement, an expert elicitation process was used to obtain values that are representative of the state of knowledge and uncertainties within the scientific community. For low probability ground motions, additional information (geologic data, laboratory testing, numerical modeling of tuff deformation, ground-motion site-response modeling) has been considered to assess how representative calculated ground motions are of those experienced at Yucca Mountain during the past 13 million years.

\subsection{ACCEPTANCE/COMPLETION CRITERIA}

Products developed under this TWP will support the license application and the licensing defense process. As such, they are expected to address, in whole or in part, acceptance criteria from Yucca Mountain Review Plan, Final Report (NRC 2003 [DIRS 163274]) (YMRP). Relevant acceptance criteria from the YMRP (NRC 2003 [DIRS 163274]) and products developed within the Disruptive Events/Seismic Studies organization under this TWP are summarized in Table 3.

Table 3. Yucca Mountain Review Plan Acceptance Criteria and Products Developed under this Technical Work Plan that Address the Criteria

\begin{tabular}{|c|c|}
\hline Yucca Mountain Review Plan Acceptance Criteria ${ }^{a}$ & $\begin{array}{c}\text { Disruptive Events/Seismic Organization Products } \\
\text { that Address Acceptance Criteria in Whole or in } \\
\text { Part }\end{array}$ \\
\hline $\begin{array}{l}\text { Section 1.5.3 (Description of Site Characterization Work): } \\
\text { 1. The "General Information" section of the license } \\
\text { application contains an adequate description of site } \\
\text { characterization activities } \\
\text { 2. The "General Information" section of the license } \\
\text { application contains an adequate description of site } \\
\text { characterization results }\end{array}$ & $\begin{array}{l}\text { MDL-MGR-GS-000003, Development of } \\
\text { Earthquake Ground Motion Input for Preclosure } \\
\text { Design and Postclosure Performance Assessment } \\
\text { of a Geologic Repository at Yucca Mountain, NV } \\
\text { - } \\
\text { ANL-MGR-GS-000004, Peak Ground Velocities for } \\
\text { Seismic Events at Yucca Mountain, Nevada } \\
\text { - Document Identifier to-be-determined, } \\
\text { Geotechnical Data Supporting Seismic Analysis of } \\
\text { Surface Facilities and Aging Pad Areas for a } \\
\text { Geologic Repository at Yucca Mountain, Nevada } \\
\text { - 100-SOC-CY00-00100-000-00A, Supplemental } \\
\text { Soils Report }\end{array}$ \\
\hline $\begin{array}{l}\text { Section 2.1.1.1.3 (Site Description as it Pertains to } \\
\text { Preclosure Safety Analysis): } \\
\text { 5. The license application contains descriptions of the } \\
\text { site geology and seismology adequate to permit } \\
\text { evaluation of the preclosure safety analysis and the } \\
\text { geologic repository operations area design }\end{array}$ & $\begin{array}{l}\text { MDL-MGR-GS-000003, Development of } \\
\text { Earthquake Ground Motion Input for Preclosure } \\
\text { Design and Postclosure Performance Assessment } \\
\text { of a Geologic Repository at Yucca Mountain, NV } \\
\text { - Document Identifier to-be-determined, } \\
\text { Geotechnical Data Supporting Seismic Analysis of } \\
\text { Surface Facilities and Aging Pad Areas for a } \\
\text { Geologic Repository at Yucca Mountain, Nevada } \\
\text { - } 100-S 0 C-C Y 00-00100-000-00 A, \text { Supplemental } \\
\text { Soils Report }\end{array}$ \\
\hline
\end{tabular}


Table 3. Yucca Mountain Review Plan Acceptance Criteria and Products Developed under this Technical Work Plan that Address the Criteria (Continued)

\begin{tabular}{|c|c|}
\hline Yucca Mountain Review Plan Acceptance Criteria ${ }^{a}$ & $\begin{array}{c}\text { Disruptive Events/Seismic Organization Products } \\
\text { that Address Acceptance Criteria in Whole or in } \\
\text { Part }\end{array}$ \\
\hline $\begin{array}{l}\text { Section 2.1.1.3.3 (Identification of Hazards and Initiating } \\
\text { Events): } \\
\text { 1. Technical basis and assumptions for methods used } \\
\text { for identification of hazards and initiating events are } \\
\text { adequate } \\
\text { 2. Site data and system information are appropriately } \\
\text { used in identification of hazards and initiating events } \\
\text { 3. Determination of frequency or probability of } \\
\text { occurrence of hazards and initiating events is } \\
\text { acceptable } \\
\text { 4. Adequate technical bases for the inclusion and } \\
\text { exclusion of hazards and initiating events are } \\
\text { provided }\end{array}$ & $\begin{array}{l}\text { MDL-MGR-GS-000003, Development of } \\
\text { Earthquake Ground Motion Input for Preclosure } \\
\text { Design and Postclosure Performance Assessment } \\
\text { of a Geologic Repository at Yucca Mountain, NV } \\
\text { - ANL-MGR-GS-000004, Peak Ground Velocities for } \\
\text { Seismic Events at Yucca Mountain, Nevada } \\
\text { Document Identifier to-be-determined, } \\
\text { Geotechnical Data Supporting Seismic Analysis of } \\
\text { Surface Facilities and Aging Pad Areas for a } \\
\text { Geologic Repository at Yucca Mountain, Nevada. }\end{array}$ \\
\hline $\begin{array}{l}\text { Section 2.1.1.7.3.1 (Design Criteria and Design Bases): } \\
\text { 1. The relationship between the design criteria and the } \\
\text { requirements specified in } 10 \text { CFR } 63.111(a) \text { and }(b) \\
\text { [DIRS } 176544] \text {, the relationship between the design } \\
\text { bases and the design criteria, and the design criteria } \\
\text { and design bases for structures, systems, and } \\
\text { components important to safety are adequately } \\
\text { defined. }\end{array}$ & $\begin{array}{l}\text { MDL-MGR-GS-000003, Development of } \\
\text { Earthquake Ground Motion Input for Preclosure } \\
\text { Design and Postclosure Performance Assessment } \\
\text { of a Geologic Repository at Yucca Mountain, NV } \\
\text { YMPrTR-003-NP, Preclosure Seismic Design and } \\
\text { Performance Demonstration Methodology for a } \\
\text { Geologic Repository at Yucca Mountain }\end{array}$ \\
\hline $\begin{array}{l}\text { Section 2.1.1.7.3.2 (Design Methodologies): } \\
\text { 1. Geologic repository operations area design } \\
\text { methodologies are adequate. }\end{array}$ & $\begin{array}{l}\text { YMPTR-003-NP, Preclosure Seismic Design and } \\
\text { Performance Demonstration Methodology for a } \\
\text { Geologic Repository at Yucca Mountain }\end{array}$ \\
\hline $\begin{array}{l}\text { Section 2.2.1.2.2.3 (Identification of events): } \\
\text { 1. Events are adequately defined } \\
\text { 2. Probability estimates for future events are supported } \\
\text { by appropriate technical bases } \\
\text { 3. Probability model support is adequate } \\
\text { 4. Probability model parameters have been adequately } \\
\text { established } \\
\text { 5. Uncertainty in event probability is adequately } \\
\text { evaluated }\end{array}$ & $\begin{array}{l}\text { MDL-MGR-GS-000003, Development of } \\
\text { Earthquake Ground Motion Input for Preclosure } \\
\text { Design and Postclosure Performance Assessment } \\
\text { of a Geologic Repository at Yucca Mountain, NV } \\
\text { ANL-MGR-GS-000004, Peak Ground Velocities for } \\
\text { Seismic Events at Yucca Mountain, Nevada }\end{array}$ \\
\hline $\begin{array}{l}\text { Section 2.2.1.3.2.3 (Mechanical Disruption of Engineered } \\
\text { Barriers): } \\
\text { 2. Data are sufficient for model justification } \\
\text { 3. Data uncertainty is characterized and propagated } \\
\text { through the model abstraction } \\
\text { 4. Model uncertainty is characterized and propagated } \\
\text { through the model abstraction } \\
\text { 5. Model abstraction output is supported by } \\
\text { objective comparisons }\end{array}$ & $\begin{array}{l}\text { MDL-MGR-GS-000003, Development of } \\
\text { Earthquake Ground Motion Input for Preclosure } \\
\text { Design and Postclosure Performance Assessment } \\
\text { of a Geologic Repository at Yucca Mountain, NV } \\
\text { - ANL-MGR-GS-000004, Peak Ground Velocities for } \\
\text { Seismic Events at Yucca Mountain, Nevada }\end{array}$ \\
\hline
\end{tabular}

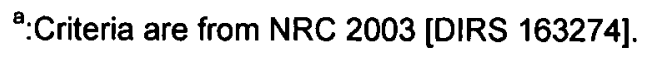

Acceptance/completion criteria defined in higher level planning for the activities and technical products developed under this TWP listed in Table 4. 
Table 4. Yucca Mountain Review Plan Acceptance Criteria and Products Developed under this Technical Work Plan that Address the Criteria

\begin{tabular}{|l|l|}
\hline \multicolumn{1}{|c|}{ Product } & \multicolumn{1}{c|}{ Acceptance/Completion Criteria } \\
\hline TWP-MGR-GS-000001 REV 05, Seismic Studies & $\begin{array}{l}\text { The TWP shall be delivered to the appropriate COR/TM and } \\
\text { reviewed in accordance with the most current approved version } \\
\text { of applicable AP-7.5Q requirements. The deliverable will be } \\
\text { acceptable when it conforms to all aspects of the deliverable } \\
\text { description and acceptance criteria specified below. }\end{array}$ \\
$\begin{array}{ll}\text { The TWP must reflect the scope of work in the Element } \\
\text { Definition Sheet and be consistent with the Deliverable } \\
\text { Description section of the Deliverable Definition Sheet. The } \\
\text { acceptance criteria for the TWP includes: } \\
\text { The scope of work described in the TWP will reflect } \\
\text { the scope in the DOE approved baseline. } \\
\text { The TWP will adequately contain all requirements } \\
\text { elements described in LP-2.29Q-BSC, Planning for } \\
\text { Science Activities. }\end{array}$ \\
$\begin{array}{l}\text { YMPrTR-003-NP, Preclosure Seismic Design and } \\
\text { Performance Demonstration Methodology for a } \\
\text { Geologic Repository at Yucca Mountain }\end{array}$ & $\begin{array}{l}\text { The deliverable shall be delivered to DOE in accordance with } \\
\text { the most current approved version of applicable AP-7.5Q, } \\
\text { Submittal, Review, and Acceptance of Deliverables } \\
\text { requirements. This deliverable will be reviewed by DOE in } \\
\text { accordance with the most current approved version of AP-7.5Q } \\
\text { to ensure that it is complete and conforms to all aspects of the } \\
\text { Deliverable Description, the Completion Criteria specified } \\
\text { below [C2], and the requirements of AP-7.5Q. }\end{array}$ \\
\hline
\end{tabular}

Acceptance criteria for subcontracted work will be addressed in procurement documentation when services are procured.

\subsection{REQUIREMENTS MANAGEMENT SYSTEM REQUIREMENTS}

The Requirements Management System does not allocate any requirements to the work activities or products planned under this TWP.

\subsection{REQUIREMENTS IDENTIFIED IN SOURCE DOCUMENTS}

Seismic-related information that is required by the RPM Engineering organization is documented in the following information exchange drawings:

- 100-IED-WHS0-00101-000-00B, IED Surface Facility

- 800-IED-MGR0-00201-000-00B, D\&E/PA/C IED Emplacement Drift Configuration and Environment

- 800-IED-WIS0-00501-000-00A, IED Waste Package Processes, Ground Motion Time. Histories, and Testing and Materials

- 800-IED-WIS0-01801-000-00A, IED Subsurface Facilities Geological Data. 


\section{IMPLEMENTING DOCUMENTS}

This section identifies the key implementing procedures that will be required to conduct the activities. Use of additional implementing procedures, as appropriate, is not precluded. If any of the listed procedures are revised or superseded, the current version will be used when the work is performed.

Key implementing documents are:

- PA-PRO-0601, Document Review, for interdisciplinary review of model, analysis, and technical reports

- PA-PRO-0308, Testing Work Implementation and Control, for development of Field Work Packages controlling the field testing activities described in this TWP, as needed; additional implementing documents will be identified in the FWP

- LP-12.1Q-BSC, Control of Measuring and Test Equipment, for control and calibration of equipment using in laboratory and field testing

- IT-PRO-0011, Software Management, for qualification and use of software in quality affecting tasks

- IT-PRO-0012, Qualification of Software, for qualification of software

- IT-PRO-0013, Software Independent.Verification and Validation, for qualification of software

- IT-PRO-0014, Independent.Verification and Validation of Legacy Code, for verification and validation of legacy code (i.e., code qualified prior to January 13, 2003) whose use will support the license application

- AP-SIII.3Q, Submittal and Incorporation of Data to the Technical Data Management System, for submittal of data to the TDMS

- LP-SIII.9Q-BSC, Scientific Analyses, for documentation of analysis activities

- LP-SIII.10Q-BSC, Models, for documentation of the modeling activities and any supporting analyses

- LP-SIII.11Q-BSC, Scientific Notebooks, for documentation of day-to-day analysis and modeling tasks

- IT-PRO-0009, Control of the Electronic Management of Information, to control management and transfer of electronic data among members of the seismic team

- PA-PRO-0309, Laboratory Geotechnical Testing of Soil, Rock, and Aggregate Samples, to control geotechnical testing of rock and soil samples 
- PA-PRO-0310, Laboratory Dynamic Rock/Soil Testing, to determine dynamic material properties of rock and soil samples

- PA-PRO-0313, Technical Reports, for revision of YMP/TR-0003-NP, Preclosure Seismic Design Methodology for a Geologic Repository at Yucca Mountain

- PA-PRO-0805, Sample Management Facility Monitoring and Documentation of Drilling Activities and Depth Control, to control support to drilling activities

- PA-PRO-0806, Sample Management Logging, Handling, and Documentation of Borehole Samples, to control sample collection activities in the field

- PA-PRO-0807, Sample Management Facility Transport, Receipt, Admittance, and Processing of Borehole Samples, to control sample related activities at the Sample Management Facility

- PA-PRO-0809, Removal, Shipment, and Return of Specimens Curated by the Sample Management Facility, to control transfer of samples for laboratory testing of dynamic material properties

- PA-PRO-0802, Examination of Borehole Samples Curated by the Sample Management Facility, to control examination of borehole samples related to development of geologic borehole logs

- YMP-USGS-GP-57, Determining Unified Soil Classification (Visual Method), to characterize materials underlying the surface facilities area

- YMP-USGS-GP-58, Engineering Geologic Logging of Rock, to develop geologic logs of the excavated boreholes at the surface facilities area.

While the stochastic point-source and finite-source ground motion models were not developed under the auspices of the YMP, LP-SIII.10Q-BSC will be used to document the preexisting models and preexisting relevant validation activities. The models and validation activities will be summarized with references to the reports in which they are documented.

With respect to work controlled by LP-SIII.11Q-BSC, Scientific Notebooks, multiple scientific notebooks will support the field and laboratory studies. Relevant notebooks that are currently open include:

- SN-M\&O-SCI-047-V1, Spectral Analysis of Surface Waves (SASW) Measurements at Yucca Mountain (Stokoe and Wong 2005 [DIRS 173748])

- SN-M\&O-SCI-048-V1, Dynamic Laboratory Testing of Tuff Samples (Wong and Stokoe 2005 [DIRS 173749]).

Additional scientific notebooks (or volumes) will be opened in accordance with LP-SIII.11Q-BSC, or technical procedures will be prepared, as needed to support the work. 
In addition, procedures referenced in the above implementing documents and procedures for support activities (e.g., document control, records management) will be used to control the work effort.

For work that is not quality affecting, LP-SIII.9Q-BSC, LP-SIII.10Q-BSC, and/or LP-SIII.11Q-BSC will be used to document the work.

\section{EQUIPMENT}

Field and laboratory systems are necessary to perform the testing activities described in this TWP. Equipment will be used for drilling and excavating, borehole geophysical logging, SASW surveys, rock and soil engineering testing, and laboratory testing. Use of measuring and test equipment, including calibration, will be controlled in accordance with LP-12.1Q-BSC, Control of Measuring and Test Equipment.

Details for equipment used in field studies will be provided in a field work package developed in accordance with PA-PRO-0308, Testing Work Implementation and Control (e.g., ORD 2004 [DIRS 173744], ORD 2005 [DIRS 173745]). Laboratory equipment consists of scales, balances, and a RCTS testing system. Scales and balances need to be checked with a YMP approved calibrated weight set prior to weighing samples and weekly thereafter during testing. In addition, the following components of the RCTS testing system need to be calibrated: universal counter, multimeter, dynamic signal analyzer, charge amplifier, accelerometer, gage blocks, signal conditioner, and pressure transducer. Calibration of measuring and test equipment used in laboratory testing is addressed in PA-PRO-0309, Laboratory Geotechnical Testing of Soil, Rock, and Aggregate Samples, and PA-PRO-0310, Laboratory Dynamic Rock/Soil Testing. As necessary, additional equipment and calibration of measuring and test equipment will be described in technical procedures or in scientific notebooks.

Major field or laboratory systems are not required to perform all other tasks and activities.

\section{RECORDS}

Records identified in any implementing procedures used shall be collected and submitted to the Records Processing Center in accordance with AP-17.1Q, Records Management.

\section{QUALITY VERIFICATIONS}

There are no specific quality verifications, other than self-assessments, surveillances or audits that are required during execution of activities described in this TWP.

\section{PREREQUISITES, SPECIAL CONTROLS, ENVIRONMENTAL CONDITIONS, PROCESSES, OR SKILLS}

This section documents whether each planned task is subject to the requirements of the Quality Assurance Requirements and Description (QARD) (DOE 2006 [DIRS 176927]) and, if not, whether the activity is subject to the Augmented Quality Assurance Program (AQAP) (DOE 2004 [DIRS 171341]). In addition, it describes any prerequisites that must be satisfied, results of the evaluation required by IT-PRO-0009, Control of the Electronic Management of 
Information, whether any special environmental controls are required, and whether there are any training or qualification requirements for personnel performing the work activity.

\subsection{DETERMINATION OF THE APPLICABILITY OF REQUIREMENTS OF THE QARD}

Testing tasks to support development of seismic inputs are subject to the QARD (DOE 2006 [DIRS 176927]). These tasks are related to characterization and include the acquisition, control, and analysis of data. Scoping activities that may be performed to investigate new testing approaches are not subject to the QARD (DOE 2006 [DIRS 176927]), but will be controlled using the same implementing procedures as quality-affecting work.

With respect to drilling activities, craft or subcontract labor, equipment, and material support are not subject to the QARD (DOE 2006 [DIRS 176927]). Support to drilling from the Sample Management Facility (including the control of samples that originate from drilling), however, is subject to the QARD (DOE 2006 [DIRS 176927]). Non-Q testing activities that take place at the Yucca Mountain Site are subject to the AQAP because they involve Yucca Mountain Site Operations. Planning for such activities is documented in field work plans.

Tasks to develop and update 'velocity profiles, dynamic material property curves, and seismic inputs support preclosure design and safety analyses and total system performance assessment. Thus, they are subject to the QARD (DOE 2006 [DIRS 176927]). Similarly, tasks to validate models and to enhance the technical basis for validation of a previously validated model are subject to the QARD because the models may be used to support design or performance assessment analyses. Scoping activities that may be performed to investigate new analysis and modeling approaches are not subject to the QARD (DOE 2006 [DIRS 176927]), but will be controlled using the same implementing procedures as quality-affecting work.

\subsection{PREREQUISITES}

For testing tasks to support development of seismic inputs, prerequisites include procurement tasks, calibration tasks, and, for fieldwork, development of a field work plan (if not already in place) and permitting and environmental clearance tasks.

For the analysis and modeling tasks to update seismic inputs, there are no prerequisites that must be satisfied before work begins other than acquisition of data through the testing tasks. The organizations involved in acquiring the data are identified in Section 1.3 of this TWP.

\subsection{CONTROL OF ELECTRONIC MANAGEMENT OF DATA}

An evaluation conducted per IT-PRO-0009, Control of the Electronic Management of Information, determined that electronic data requiring controls are involved in this work. To provide assurance of the integrity of transferred data, controls for transfer of electronic information consist of check sums, parity checks, and file-size comparisons performed by computer operating systems during data transfer and storage. In addition, to ensure that data integrity is maintained, compressing or "zipping" data files prior to transfer will be performed in cases in which data are transferred from one physical location to another. Security and integrity of the electronic information developed during the work activities will be maintained by storing 
the information on network drives and on hard drives of password-protected personal computers. Network drives and hard drives will be periodically backed up, as appropriate, and the backups labeled and stored. This will also ensure that data are protected prior to submittal to the records system and that they are retrievable. When electronic information is submitted to the records system or the TDMS, controls established in the relevant procedures will be followed. Any additional controls on electronic management of information will be described in scientific notebooks or reports documenting the work. Additional requirements with respect to the electronic management of data are identified in procedures listed in Section 4 (e.g., AP-SIII.3Q).

\subsection{ENVIRONMENTAL CONDITIONS}

For testing tasks, special environmental controls may apply to sample packaging and subsequent storage. Any such controls shall be identified on the Sample Overview Committee Field Packaging Approval form developed in accordance with PA-PRO-0803, Requesting, Transferring, and Returning. Yucca Mountain Project Specimens from the Sample Management Facility. There are no special environmental controls associated with analysis and modeling tasks.

\subsection{QUALIFICATION OF PERSONNEL}

Qualified individuals will perform the work and will be trained in accordance with their job functions. Personnel involved in field testing activities will be trained as required for such work. There are no special training or qualification requirements for personnel carrying out the work.

\section{SOFTWARE}

This section lists software codes expected to be used to conduct the activities described in this TWP. Software not qualified at the time this TWP is approved will be qualified for use in work subject to requirements of the QARD (DOE 2006 [DIRS 176927]). Software, along with its qualification status and tracking number, are listed in Table 5.

Table 5. Software to be used in Work Subject to Requirements of the QARD

\begin{tabular}{|c|c|c|}
\hline Program Name & Status & $\begin{array}{l}\text { Software } \\
\text { Tracking } \\
\text { Number }\end{array}$ \\
\hline 3DEC V2.01 [BSC 2002 [DIRS 161930]) & Qualified & $10025-2.01-00$ \\
\hline AMOD (TBD) & Not yet qualified & To be determined \\
\hline BASE4 V4.0 (Pacific Engineering and Analysis 2002 [DIRS 163293]) & Qualified & $10940-4.0-00$ \\
\hline BIAS V1.0 (Pacific Engineering and Analysis 2004 [DIRS 173756]) & Qualified & $11126-1.0-00$ \\
\hline CMB_FRAC V2.0 (Risk Engineering 2002 [DIRS 163294]) & Qualified & $10464-2.0-00$ \\
\hline CORBB V1:0 (Pacific Engineering and Analysis 2002 [DIRS 163295]) & Qualified & $10941-1.0-00$ \\
\hline DESIGN_EVENTS V1.0 (Risk Engineering 2002 [DIRS 163302]) & Qualified & $10362-1.0-00$ \\
\hline DESRA (TBD) & Not yet qualified & To be determined \\
\hline DUR V1.0 (Pacific Engineering and Analysis 2003 [DIRS 163303]) & Qualified & $10942-1.0-00$ \\
\hline EARTHVISION V5.1 (Dynamic Graphics 2000 [DIRS 167994]) & Qualified & $10174-5.1-00$ \\
\hline FRISK88 V2.0 (Risk Engineering 2000 [DIRS 163365]) & Qualified & $10139-2.0-00$ \\
\hline HAZUHS V1.0 (TBD) & Not yet qualified & $11194-1.0-00$ \\
\hline
\end{tabular}


Table 5. Software to be used in Work Subject to Requirements of the QARD (Continued)

\begin{tabular}{|c|c|c|}
\hline Program Name & Status & $\begin{array}{l}\text { Software } \\
\text { Tracking } \\
\text { Number }\end{array}$ \\
\hline INTCOR V1.0 (TBD) & Not yet qualified & To be determined \\
\hline INTEG1 V1.0 (Pacific Engineering and Analysis 2002 [DIRS 163304]) & Qualified & $10943-1.0-00$ \\
\hline INTERPOL V1.0 (Pacific Engineering and Analysis 2002 [DIRS 163305]) & Qualified & $10944-1.0-00$ \\
\hline KSLIP V1.1 (TBD) & Not yet qualified & To be determined \\
\hline LAYERING V1.0 (Risk Engineering 2002 [DIRS 163307]) & Qualified & 10648-1.0-00 \\
\hline MAXMIN V1.0 (Pacific Engineering and Analysis 2002 [DIRS163309]) & Qualified & $10945-1.0-00$ \\
\hline MEAN V1.1 (Risk Engineering 2002 [DIRS 163310]) & Qualified & $10463-1.1-00$ \\
\hline NFITM V3.41 (TBD) & Not yet qualified & $10385-3.41-00$ \\
\hline PFC2D V2.0 (BSC 2004 [DIRS 169930]) & Qualified & $10828-2.0-01$ \\
\hline PFC3D V2.0 (BSC 2004 [DIRS 169931]) & Qualified & $10830-2.0-01$ \\
\hline POST88 V1.0 (Risk Engineering 2000 [DIRS 163361]) & Qualified & $10136-1.0-00$ \\
\hline POST RASCAL SET V1.0 (TBD) & Not yet qualified & $11231-1.0-00$ \\
\hline PREP88 V1.0 (Risk Engineering 2000 [DIRS 163362]) & Qualified & $10138-1.0-00$ \\
\hline RASCALFS V2.0 (TBD) & Not yet qualified & $11124-2.0-00$ \\
\hline RASCALS SET V1.0 (TBD) & Not yet qualified & $11232-1.0-00$ \\
\hline REPLOT V1.0 (Pacific Engineering and Analysis 2003 [DIRS 163318]) & Qualified & $10949-1.0-00$ \\
\hline SCALE1 V1.0 (Pacific Engineering and Analysis 2002 [DIRS 163319]) & Qualified & $10946-1.0-00$ \\
\hline SIGCOMB V1.0 (TBD) & Not yet qualified & $11233-1.0-00$ \\
\hline SOILHAZ SET V1.0 (TBD) & Not yet qualified & $11234-1.0-00$ \\
\hline SPCTLR V1.0 (Pacific Engineering and Analysis 2003 [DIRS 163321]) & Qualified & $10947-1.0-00$ \\
\hline SUMDES (TBD) & Not yet qualified & To be determined \\
\hline TESS (TBD) & Not yet qualified & To be determined \\
\hline UDEC V3.14 (BSC 2004 [DIRS 172322]) & Qualified & 10173-3.14-00 \\
\hline VEL_SIMUL V1.0 (Risk Engineering 2002 [DIRS 163323]) & Qualified & $10647-1.0-00$ \\
\hline VEL_STAT V1.0 (Risk Engineering 2002 [DIRS 163324]) & Qualified & $10646-1.0-00$ \\
\hline VSUM V1.0 (TBD) & Not yet qualified & To be determined \\
\hline XYMULT V1.0 (Pacific Engineering and Analysis 2002 [DIRS 163326]) & Qualified & $10919-1.0-00$ \\
\hline WESSA V3.1 (TBD) & Not yet qualified & $11196-1.0-00$ \\
\hline WinSASW V1.23 (University of Texas 2002 [DIRS 159433]) & Qualified & $10588-1.23-00$ \\
\hline
\end{tabular}

A program to implement inversion of SASW data dispersion curves for velocity profiles to corroborate forward-modeling results has not yet been identified. If, as work subject to the requirements of the QARD (DOE 2006 [DIRS 176927]) progresses, it is determined that additional programs are required, that existing programs need to be modified to better serve their intended purposes, or that new versions of acquired programs are available, those programs will be addressed in accordance with IT-PRO-0011, Software Management, and related procedures.

In carrying out work subject to the requirements of the QARD (DOE 2006 [DIRS 176927]), it is anticipated that exempt software (per IT-PRO-0011, Section 1.4) will also be employed (e.g., Microsoft Excel, gINT). Documentation of the use of such software will be done in accordance with applicable procedures (e.g., LP-SIII.10Q-BSC and LP-SIII.9Q-BSC). 
Legacy software (i.e., software qualified prior to January 13, 2003) whose use will support the license application is subject to verification and validation in accordance with IT-PRO-0014, Independent Verification and Validation of Legacy Code.

It is not anticipated that any continuous use software will be used in the planned work activities.

\section{ORGANIZATIONAL INTERFACES}

This section describes organizational interfaces, including input and customer organizations that are external to the Postclosure Activities organization. The section also discusses their roles and responsibilities. Input organizations and customer organizations also exist internal to the Postclosure Activities organization, as discussed in Section 2.1.

\subsection{INPUT ORGANIZATIONS}

The RPM Engineering organization provides the footprint of the planned waste emplacement area and the layout of the surface facilities. These inputs are used in developing velocity profiles. Data from boreholes or velocity surveys falling within or near the repository footprint or surface facilities that are important-to-safety form the primary data set used in developing velocity profiles.

\subsection{CUSTOMER ORGANIZATIONS}

Organizations that will use the outputs of this work are as follows:

- Licensing

- Results of the planned work will be used in licensing defense and for the license application or updates

- Technical, topical, or methodology reports on seismic issues will be used in prelicensing interactions with the NRC

- Preclosure Safety Analysis

- Ground motion hazard curves for the surface facilities area will be used in analyses of preclosure safety

- RPM Engineering

- Updated ground motion inputs will be used for future analyses supporting surface facilities design and soil-structure interaction analyses for licensing defense

- Updated ground motion inputs will be used for future analyses supporting preclosure subsurface facilities design for licensing defense

If the proposed activities described in Section 1.2 are approved, the interim updated ground motion inputs will be used for design analyses supporting the license application. 


\subsection{OTHER ORGANIZATIONAL INTERFACES}

There is one organizational interface that does not involve input or customer organizations. The University of Nevada, Reno carries out seismic monitoring and analysis under a cooperative agreement with the DOE. Results of their activities form part of the data that will be used in tasks to expand and enhance the technical basis for model validation.

\section{PROCUREMENT}

Procurements are anticipated to support the activities described in this TWP. Procurements for analysis and modeling tasks will include technical services contracts or staff augmentation contracts. Procurements for testing tasks will include those for drilling, logging, velocity surveys, and laboratory services. Procurements that represent a follow-on to previous related work may be made on a sole source basis. Acceptance criteria for subcontracted work will be addressed in procurement documentation when services are procured.

BSC subcontracts are identified and processed using EG-PRO-3DP-G06B-00002, Subcontracts, and related procedures. BSC Technical Service Agreements are identified and processed using EG-PRO-3DP-G04B-00057, Technical Service Contracts, and related procedures.

Any procurement made by USGS or BOR personnel will be in accordance with YMP-USGS-QMP-4.01, Procurement Document Control/Receipt of Procurements, and YMP-USGS-QMP-4.02, Control of Agreements.

\section{REFERENCES}

\subsection{DOCUMENTS CITED}

157829 BSC (Bechtel SAIC Company) 2002. Geotechnical Data for a Potential Waste Handling Building and for Ground Motion Analyses for the Yucca Mountain Site Characterization Project. ANL-MGR-GE-000003 REV 00. Las Vegas, Nevada: Bechtel SAIC Company. ACC: MOL.20021004.0078.

166274 BSC 2003. Development of Earthquake Ground Motion Input for Preclosure Seismic Design and Postclosure Performance Assessment of a Geologic Repository at Yucca Mountain, NV. MDL-MGR-GS-000003 REV 00. Las Vegas, Nevada: Bechtel SAIC Company. ACC: DOC.20031201.0001.

171717 BSC 2004. Additional Structural Calculations of Waste Package Exposed to Vibratory Ground Motion. 000-00C-WIS0-01700-000-00B. Las Vegas, Nevada: Bechtel SAIC Company. ACC: ENG.20041027.0001.

168030 BSC 2004. Characterize Framework for Seismicity and Structural Deformation at Yucca Mountain, Nevada. ANL-CRW-GS-000003 REV 00 [Errata 001]. Las Vegas, Nevada: Bechtel SAIC Company. ACC: MOL.20000510.0175; DOC.20040223.0007. 
168780 BSC 2004. Development of Earthquake Ground Motion Input for Preclosure Seismic Design and Postclosure Performance Assessment of a Geologic Repository at Yucca Mountain, NV. MDL-MGR-GS-000003 REV 00 [Errata 001]. Las Vegas, Nevada: Bechtel SAIC Company. ACC: DOC.20031201.0001; DOC.20040401.0004.

170027 BSC 2004. Development of Earthquake Ground Motion Input for Preclosure Seismic Design and Postclosure Performance Assessment of a Geologic Repository at Yucca Mountain, NV. MDL-MGR-GS-000003 REV 01. Las Vegas, Nevada: Bechtel SAIC Company. ACC: DOC.20041111.0006.

171850 BSC 2004. Development of Seismic Inputs, Preparation of Seismic Topical Reports, and Evaluation of Disruptive Events Features, Events, and Processes. TWP-MGR-GS-000001 REV 03 ICN 02. Las Vegas, Nevada: Bechtel SAIC Company. ACC: DOC.20040923.0001.

166107 BSC 2004. Drift Degradation Analysis. ANL-EBS-MD-000027 REV 03. Las Vegas, Nevada: Bechtel SAIC Company. ACC: DOC.20040915.0010.

170029 BSC 2004. Geologic Framework Model (GFM2000). MDL-NBS-GS-000002 REV 02. Las Vegas, Nevada: Bechtel SAIC Company. ACC: DOC.20040827.0008.

169183 BSC 2004. Seismic Consequence Abstraction. MDL-WIS-PA-000003 REV 01. Las Vegas, Nevada: Bechtel SAIC Company. ACC: DOC.20041025.0004.

172448 BSC 2004. Structural Calculations of Drip Shield Exposed to Vibratory Ground Motion. 000-00C-WIS0-02500-000-00A. Las Vegas, Nevada: Bechtel SAIC Company. ACC: ENG.20041111.0002.

167083 BSC 2004. Structural Calculations of Waste Package Exposed to Vibratory Ground Motion. 000-00C-WIS0-01400-000-00A. Las Vegas, Nevada: Bechtel SAIC Company. ACC: ENG.20040217.0008.

166067 BSC 2004. Supplemental Soils Report. 100-S0C-CY00-00100-000-00A. Las Vegas, Nevada: Bechtel SAIC Company. ACC: ENG.20041108.0006.

169886 BSC 2004. Technical Work Plan for: Development of Seismic Inputs, Preparation of Seismic Topical Reports, and Evaluation of Disruptive Events Features, Events, and Processes. TWP-MGR-GS-000001 REV 03 ICN 01. Las Vegas, Nevada: Bechtel SAIC Company. ACC: DOC.20040601.0001.

173981 BSC 2005. Features, Events, and Processes: Disruptive Events. ANL-WIS-MD000005 REV 03. Las Vegas, Nevada: Bechtel SAIC Company.

ACC: DOC.20050830.0008. 
176805 BSC 2005. IED Subsurface Facilities Layout Geographical Data [Sheet 1 of 1]. 800-IED-WIS0-01701-000-00A. Las Vegas, Nevada: Bechtel SAIC Company. ACC: ENG.20051103.0003.

170137 BSC 2005. Peak Ground Velocities for Seismic Events at Yucca Mountain, Nevada. ANL-MGR-GS-000004 REV 00. Las Vegas, Nevada: Bechtel SAIC Company. ACC: DOC.20050223.0002.

173247 BSC 2005. Seismic Consequence Abstraction. MDL-WIS-PA-000003 REV 02. Las Vegas, Nevada: Bechtel SAIC Company. ACC: DOC.20050829.0005.

177243 BSC 2006. Technical Work Plan for: Calculation of Waste Package and Drip Shield Response to Vibratory Ground Motion and Revision of the Seismic Consequence Abstraction. TWP-MGR-GS-000004 REV 01. Las Vegas, Nevada: Bechtel SAIC Company. ACC: DOC.20060713.0003.

171341 DOE (U.S. Department of Energy) 2004. Augmented Quality Assurance Program (AQAP). DOE/RW-0565, Rev. 0. Washington, D.C.: U.S. Department of Energy, Office of Civilian Radioactive Waste Management.

ACC: DOC.20040813.0001.

172373 DOE 2004. Preclosure Seismic Design Methodology for a Geologic Repository at Yucca Mountain. Topical Report YMP/TR-003-NP, Rev. 3. Las Vegas, Nevada: U.S. Department of Energy, Office of Repository Development. ACC: MOL.20041103.0002.

176927 DOE 2006. Quality Assurance Requirements and Description. DOE/RW-0333P, Rev. 17. Washington, D.C.: U.S. Department of Energy, Office of Civilian Radioactive Waste Management. ACC: DOC.20060504.0008.

103322 EPRI (Electric Power Research Institute) 1993. Appendices for Laboratory Investigations. Volume 4 of Guidelines for Determining Design Basis Ground Motions. EPRI TR-102293. Palo Alto, California: Electric Power Research Institute. TIC: 226498.

$157248 \quad$ Joh, S.-H. 1996. Advances in the Data Interpretation Technique for Spectral-Analysis-of-Surface-Waves (SASW) Measurements. Ph.D. dissertation. Austin, Texas: University of Texas at Austin. TIC: 252117.

$176995 \quad$ Kokajko, L.E. 2006. "Preclosure Seismic Design Methodology and Performance Demonstration." Letter from L.E. Kokajko (NRC) to M.H. Williams (DOE/ORD), January 24, 2006, 0202067669. ACC: MOL.20060313.0183.

157510 McGuire, R.K.; Silva, W.J.; and Costantino, C.J. 2001. Technical Basis for Revision of Regulatory Guidance on Design Ground Motions: Hazard-and Risk-Consistent Ground Motion Spectra Guidelines. NUREG/CR-6728. Washington, D.C.: U.S. Nuclear Regulatory Commission. TIC: 251294. 
McGuire, R.K.; Silva, W.J.; and Costantino, C.J. 2002. Technical Basis for Revision of Regulatory Guidance on Design Ground Motions: Development of Hazard-and Risk-Consistent Seismic Spectra for Two Sites. NUREG/CR-6769. A-64Washington, D.C.: U.S. Nuclear Regulatory Commission. TIC: 254478.

163274 NRC (U.S. Nuclear Regulatory Commission) 2003. Yucca Mountain Review Plan, Final Report. NUREG-1804, Rev. 2. Washington, D.C.: U.S. Nuclear Regulatory Commission, Office of Nuclear Material Safety and Safeguards. TIC: 254568 .

170203 ORD (Office of Repository Development) 2003. Geologic Mapping. Field Work Package FWP-ESF-PA-001, Rev. 0. Las Vegas, Nevada: U.S. Department of Energy, Office of Repository Development. ACC: SIT.20030721.0003.

$173744 \quad$ ORD 2004. Repository Facilities Geotechnical Investigations. FWP-SBT-PA-000005, Rev 000. Las Vegas, Nevada: U.S. Department of Energy, Office of Repository Development. ACC: SIT.20040929.0220.

173745 ORD 2005. SASW Investigations for Repository Facilities. FWP-SBT-PA-000003, Rev 01. Las Vegas, Nevada: U.S. Department of Energy, Office of Repository Development. ACC: SIT.20050224.0002.

160060 Potter, C.J.; Dickerson, R.P.; Sweetkind, D.S.; Drake, R.M., II; Taylor, E.M.; Fridrich, C.J.; San Juan, C.A.; and Day, W.C. 2002. Geologic Map of the Yucca Mountain Region, Nye County, Nevada. Geologic Investigations Series I-2755. Denver, Colorado: U.S. Geological Survey. TIC: 253945.

167793 Quittmeyer, R. 2004. Technical Work Plan for: Development of Seismic Inputs, Preparation of Seismic Topical Reports, and Evaluation of Disruptive Events Features, Events, and Processes. TWP-MGR-GS-000001 REV 03. Las Vegas, Nevada: Bechtel SAIC Company. ACC: DOC.20040223.0004.

103324 Seed, H.B. and Idriss, I.M. 1970. Soil Moduli and Damping Factors for Dynamic Response Analyses. EERC 70-10. Berkeley, California: University of California, Earthquake Engineering Research Center. TIC: 241070.

103326 Silva, W.J. 1976. "Body Waves in a Layered Anelastic Solid." Bulletin of the Seismological Society of America, 66, (5), 1539-1554. El Cerrito, California: Seismological Society of America. TIC: 241277.

103325 Silva, W.J. and Lee, K. 1987. State-of-the-Art for Assessing Earthquake Hazards in the United States. Report 24, WES RASCAL Code for Synthesizing Earthquake Ground Motions. Miscellaneous Paper S-73-1. Washington, D.C.: U.S. Department of the Army. TIC: 241388.

110474 Silva, W.J.; Abrahamson, N.; Toro, G.; and Costantino, C. 1996. Description and Validation of the Stochastic Ground Motion Model. PE\&A 94PJ20. El Cerrito, California: Pacific Engineering and Analysis. TIC: 245288. 
157265 Stokoe, K.H., II.; Wright, S.G.; Bay, J.A.; and Roësset, J.M. 1994.

"Characterization of Geotechnical Sites by SASW Method." Volume Prepared by ISSMFE Technical Committee \#10 for XIII ICSMFE, 1994, New Delhi, India. Woods, R.D., ed. New York, New York: International Science Publisher. TIC: 251421.

173748 Stokoe, K. and Wong, I.G. 2005. Spectral Analysis of Surface Waves (SASW) Measurements at Yucca Mountain [partial submittal]. Scientific Notebook SNM\&O-SCI-047-V1. Pages 19-149. ACC: MOL.20060327.0110.

158784 Swan, F.H.; Wesling, J.R.; Angell, M.M.; Thomas, A.P.; Whitney, J.W.; and Gibson, J.D. 2001. Evaluation of the Location and Recency of Faulting Near Prospective Surface Facilities in Midway Valley, Nye County, Nevada. Open-File Report 01-55. Denver, Colorado: U.S. Geological Survey. TIC: 251592.

173749 Wong, I.G. and Stokoe, K. 2005. Dynamic Laboratory Testing of Tuff Samples [partial submittal]. Scientific Notebook SN-M\&O-SCI-048-V1. Pages 1-108 ACC: MOL.20051117.0072.

150629 YMP (Yucca Mountain Site Characterization Project) 1999. Surface-Based Borehole Instrumentation and Monitoring. Field Work Package FWP-SB-97-009, Rev. 1. Las Vegas, Nevada: Yucca Mountain Site Characterization Office. ACC: MOL.19991014.0231.

\subsection{CODES, STANDARDS, REGULATIONS, AND PROCEDURES}

176544 10 CFR 63. 2005 Energy: Disposal of High-Level Radioactive Wastes in a Geologic Repository at Yucca Mountain, Nevada. Internet Accesible.

17735171 FR 29369. Notice of Availability of Draft Interim Staff Guidance Document HLWRS-ISG-01 Review Methodology for Seismically Initiated Event Sequences. Internet Accessible.

169347 Regulatory Guide 1.132, Rev. 2. 2003. Site Investigations for Foundations of Nuclear Power Plants. 2003. Washington, D.C.: U.S. Nuclear Regulatory Commission. Readily available.

\subsection{SOFTWARE CODES}

161930 BSC 2002. Software Code: 3DEC. V2.01. PC WINDOWS 2000/NT 4.0. 10025-2.01-00.

169930 BSC 2004. Software Code: PFC2D. V 2.0. PC, Windows 2000. 10828-2.0-01.

169931 BSC 2004. Software Code: PFC3D. V 2.0. PC, Windows 2000. 10830-2.0-01.

172322 BSC 2004. Software Code: UDEC. V3.14. PC, WINDOWS 2000. 10173-3.14-00. 
167994 Dynamic Graphics 2000. Software Code: EARTHVISION. V5.1. SGI/IRIX 6.5. 10174-5.1-00.

163293 Pacific Engineering and Analysis. 2002. Software Code: BASE4. V4.0. PC, DOS 6.22. 10940-4.0-00.

163295 Pacific Engineering and Analysis 2002. Software Code: CORBB. V 1.0. PC, DOS 6.22. 10941-1.0-00.

163304 Pacific Engineering and Analysis. 2002. Software Code: INTEG1. V1.0. PC, DOS 6.22. 10943-1.0-00.

163305 Pacific Engineering and Analysis. 2002. Software Code: INTERPOL. V1.0. PC, DOS 6.22. 10944-1.0-00.

163309 Pacific Engineering and Analysis. 2002. Software Code: MAXMIN. V1.0. PC, DOS 6.22. 10945-1.0-00.

163319 Pacific Engineering and Analysis. 2002. Software Code: SCALE1. V1.0. PC, DOS 6.22. 10946-1.0-00.

163326 Pacific Engineering and Analysis. 2002. Software Code: XYMULT. V1.0. PC, DOS 6.22. 10919-1.0-00.

163303 Pacific Engineering and Analysis. 2003. Software Code: DUR. V1.0. PC, DOS 6.22. 10942-1.0-00.

163318 Pacific Engineering and Analysis. 2003. Software Code: REPLOT. V1.0. PC, DOS 6.22. 10949-1.0-00.

163321 Pacific Engineering and Analysis. 2003. Software Code: SPCTLR. V1.0. PC, DOS 6.22. 10947-1.0-00.

173756 Pacific Engineering and Analysis 2004. Software Code: BIAS. V 1.0. PC, DOS 6.22. 11126-1.0-00.

163365 Risk Engineering, Inc. 2000. Software Code: FRISK88. V2.0. HP-735, HP-UX 10.01. 10139-2.0-00.

163361 Risk Engineering, Inc. 2000. Software Code: POST88. V1.0. HP-735, HP-UX 10.01. 10136-1.0-00.

163362 Risk Engineering, Inc. 2000. Software Code: PREP88. V1.0. HP-735, HP-UX 10.01. 10138-1.0-00.

163294 Risk Engineering, Inc. 2002. Software Code: CMB.FRAC. V2.0. HP 735, HP-UX 10.01. 10464-2.0-00. 
163302 Risk Engineering, Inc. 2002. Software Code: DESIGN_EVENTS. V1.0. PC, DOS 6.22. 10362-1.0-00.

163307 Risk Engineering, Inc. 2002. Software Code: LAYERING. V1.0. PC, Windows 98. 10648-1.0-00.

163310 Risk Engineering, Inc. 2002. Software Code: MEAN. V1.1. HP 735, HP-UX 10.01. 10463-1.1-00.

163323 Risk Engineering, Inc. 2002. Software Code: VEL_SIMUL. V1.0. PC, Windows 98. 10647-1.0-00.

163324 Risk Engineering, Inc. 2002. Software Code: VEL_STAT. V1.0. PC, Windows 98. 10646-1.0-00.

159433 University of Texas. 2002. Software Code: WinSASW. V1.23. 10588-1.23-00.

\subsection{DATA, LISTED BY DATA TRACKING NUMBER}

163777 MO0206SASWVSP1.001. Velocity Profiles for the Repository Block. Submittal date: $06 / 03 / 2002$.

163798 MO0209VELPRWHB.000. Velocity Profiles for the Waste Handling Building Site Characterization Area. Submittal date: 09/23/2002.

170434 MO0403SDIAWHBC.003. Normalized Shear Modulus and Material Damping Versus Shearing Strain Curves for Rock and Alluvium for Seismic Design Input Analyses. Submittal date: 03/26/2004. 
INTENTIONALLY LEFT BLANK 


\section{APPENDIX A}

VALIDATION SUMMARY FOR THE RANDOM VIBRATION THEORY-BASED EQUIVALENT-LINEAR GROUND-MOTION SITE-RESPONSE MODEL 
Past seismic activities have included those to: (1) validate the RVT-based equivalent-linear site-response model to Level III and (2) enhance the technical basis for the validation beyond the procedurally required level. However, as documented in CR 5824, the category into which a specific activity falls has not always been unambiguously stated in previous plans and reports (Quittmeyer 2004 [DIRS 167793], BSC 2004 [DIRS 169886], BSC 2004 [DIRS 171850], BSC 2003 [DIRS 166274], BSC 2004 [DIRS 168780]). The purpose of this appendix is to clarify what previous work has validated the model and what work has enhanced the technical basis for the validation beyond its required level of validation. This distinction is particularly important in evaluating whether an activity is subject to the requirements of the QARD (DOE 2006 [DIRS 176927]).

The validation of the RVT-based equivalent-linear site-response model was originally described in MDL-MGR-GS-000003 REV 00 (BSC 2003 [DIRS 166274]). Validation consisted of documenting previous studies, which were not conducted under the auspices of the YMP, that compared model results to data and to results using alternative (fully nonlinear) models. In addition, a technical review was performed as part of the model validation process. The review indicated that the model represents the "state-of-the-art for evaluation of site effects at soil and rock sites, including explicit evaluation of uncertainties." In addition, the review identified a number of issues that needed to be addressed and recommended additional activities to increase confidence in the model as applied to Yucca Mountain. In finalizing MDL-MGR-GS-000003 REV 00 (BSC 2003 [DIRS 166274]), the discussion of existing validation studies was strengthened to address the review comments; recommended studies to increase confidence in the model were noted, but not implemented. The report originator, checkers, Chief Science Office reviewer, lead, and responsible manager approved the final version of the report indicating that the required level of model validation had been achieved.

As a result of a surveillance associated with actions to close CR 99, CR 2084 was initiated to document that, in the view of the surveillance reviewer, MDL-MGR-GS-000003 REV 00 (BSC 2003 [DIRS 166274]) did not provide the required level of confidence that the RVT-based equivalent-linear site-response model was valid. The major conclusion of the surveillance reviewer was that ground motion inputs to the model, derived from the probabilistic seismic hazard analysis for Yucca Mountain, were unrealistic at low frequencies of exceedance, and thus the model results were not accurate for those exceedance frequencies. The originator of the report acknowledged that the low frequency of exceedance inputs was unrealistic and, in fact, the report states that observation. The resulting model outputs, while unrealistic for some cases, provided data for the intended use to evaluate the sensitivity to extreme levels of ground motion in rockfall analyses and analyses of the structural response of engineered barrier system components. To address the issues raised in the condition report, a separate analysis was performed to determine a reasonable limit to ground motion at the waste emplacement level for Yucca Mountain (ANL-MGR-GS-000004 REV 00 (BSC 2005 [DIRS 170137])). The results of this analysis are currently not incorporated in the site-response modeling and subsequent development of time histories, but rather as part of the seismic consequence abstraction model (MDL-WIS-PA-000003, REV 01 (BSC 2004 [DIRS 169183])). Discussion in MDL-MGR-GS-000003 REV 01 (BSC 2004 [DIRS 170027]) of the analysis limiting ground motions at Yucca Mountain resolved Condition Report 2084 and reestablished that the level of confidence in the RVT-based equivalent-linear site-response model meets the required level. 
In addition to discussing the analysis to limit ground motions at Yucca Mountain and resolve Condition Report 2084, MDL-MGR-GS-000003 REV 01 (BSC 2004 [DIRS 170027]) also describes an activity to enhance the technical basis for the model validation. Data from a soil site at which high strains were experienced were modeled using the RVT-based equivalent-linear site-response model and two nonlinear models (BSC 2004 [DIRS 170027], Section 7.3.5). This activity implemented one of the recommendations from the technical review of model validation originally documented in MDL-MGR-GS-000003 REV 00 (BSC 2003 [DIRS 166274]). Results of the activity are not relied upon to provide the procedurally required level of confidence in the model, but rather are used to expand and enhance the technical basis for validation beyond that level. Thus, the activity was determined to be not subject to the requirements of the QARD (DOE 2006 [DIRS 176927]) and unqualified software codes were used for the nonlinear models.

In summary, validation activities for the RVT-based equivalent-linear site-response model are documented in Development of Earthquake Ground Motion Input for Preclosure Seismic Design and Postclosure Performance Assessment of a Geologic Repository at Yucca Mountain, NV (BSC 2003 [DIRS 166274]). In response to CR 2084, the validation discussion was expanded in Development of Earthquake Ground Motion Input for Preclosure Seismic Design and Postclosure Performance Assessment of a Geologic Repository at Yucca Mountain, NV (BSC 2004 [DIRS 170027]) to reference a seismic analysis limiting ground motions at the waste emplacement level. Limitation of ground motions at the waste emplacement level is not currently used to condition inputs to the site-response model, but rather incorporated into the seismic consequence abstraction. In addition to discussion of the activities to achieve the procedurally required level of confidence in the site-response model, MDL-MGR-GS-000003 REV 01 (BSC 2004 [DIRS 170027], Section 7.3.5) also describes an activity to enhance the technical basis for model validation beyond the required level.

This TWP describes additional activities to enhance the technical basis for the site-response model beyond the procedurally required level. These additional activities are not subject to the requirements of the QARD (DOE 2006 [DIRS 176927]) (Section 8) and may, in some cases, employ unqualified software (Section 9). In future revisions of MDL-MGR-GS-000003, a clearer distinction will be made between the two categories of activities. 
APPENDIX B

TECHNICAL REVIEW FOR PURPOSES OF MODEL VALIDATION 


\section{B.1 TECHNICAL REVIEW FOR PURPOSES OF MODEL VALIDATION}

This appendix implements the requirements of LP-2.29Q-BSC, Appendix D to define subject matter expertise, qualifications for reviewer(s), criteria for selecting reviewers, and specific responsibilities for each reviewer when independent technical review is used as a method of postdevelopment model validation.

In Section 2.3, independent technical review is identified as a method of postdevelopment model validation for three models:

- An update to the treatment of P-wave propagation in the RVT-based equivalent-linear site-response model

- RVT-based point-source ground motion model

- RVT-based finite-source ground motion model

\section{B.1.1 UPDATE OF THE RVT-BASED EQUIVALENT-LINEAR SITE-RESPONSE MODEL}

Subject Matter Expertise. The technical reviewer for the update to the treatment of P-wave propagation in the RVT-based equivalent-linear site-response model will require expertise in modeling of ground-motion site response.

Reviewer Qualifications and Criteria for Selection. The technical reviewer will have a doctorate in seismology or a related field and a minimum of 5 years of experience in ground-motion siteresponse modeling. Experience can be in either a research or industry environment, or a combination of both.

Reviewer Responsibilities. The technical reviewer will be responsible for evaluating the adequacy and appropriateness of the incorporation of nonlinear P-wave propagation into the RVT-based equivalent-linear site-response model. Other aspects of the model have been previously validated and will not be a subject of the current review. It is anticipated that a single reviewer will cover all technical aspects of the review.

Review Criteria. The review criteria will be that nonlinear P-wave propagation is adequately and appropriately incorporated into the model and produces results that are in reasonable agreement with observed data considering model variability and bias.

\section{B.1.2 RVT-BASED POINT-SOURCE GROUND MOTION MODEL}

Subject Matter Expertise. The technical reviewer for RVT-based point-source ground motion model will require expertise in techniques for modeling seismic ground motion.

Reviewer Qualifications and Criteria for Selection. The technical reviewer will have a doctorate in seismology or a related field and a minimum of 5 years of experience in ground motion modeling. Experience can be in either a research or industry environment, or a combination of both. 
Reviewer Responsibilities. The technical reviewer will be responsible for evaluating the adequacy and appropriateness of the RVT-based point-source ground motion model for developing ground motions for the Yucca Mountain site. It is anticipated that a single reviewer will cover all technical aspects of the review.

Review Criteria. The review criteria will be that the RVT-based point-source ground motion model produces results that are in reasonable agreement with observed data considering model variability and bias and adequately and appropriately model ground motion for the Yucca Mountain site and environs.

\section{B.1.3 RVT-BASED FINITE-SOURCE GROUND MOTION MODEL}

Subject Matter Expertise. The technical reviewer for RVT-based finite-source ground motion model will require expertise in techniques for modeling seismic ground motion.

Reviewer Qualifications and Criteria for Selection. The technical reviewer will have a doctorate in seismology or a related field and a minimum of 5 years of experience in ground motion modeling. Experience can be in either a research or industry environment, or a combination of both.

Reviewer Responsibilities. The technical reviewer will be responsible for evaluating the adequacy and appropriateness of the RVT-based finite-source ground motion model for developing ground motions for the Yucca Mountain site. It is anticipated that a single reviewer will cover all technical aspects of the review.

Review Criteria. The review criteria will be that the RVT-based finite-source ground motion model produces results that are in reasonable agreement with observed data considering model variability and bias and adequately and appropriately model ground motion for the Yucca Mountain site and environs. 